\title{
The Diatom Genus Actinocyclus in the Western United States
}

A. Actinocyclus Species from Lacustrine Miocene Deposits of the Western Uniled States

B. Geologic Ranges of Lacustrine Species, Western United States

U.S. GEOLOGICAL SURVEY PROFESSIONAL PAPER 1543 A-B 


\section{AVAILABILITY OF BOOKS AND MAPS OF THE U.S. GEOLOGICAL SURVEY}

Instructions on ordering publications of the U.S. Geological Survey, along with prices of the last offerings, are given in the current-year issues of the monthly catalog "New Publications of the U.S. Geological Survey." Prices of available U.S. Geological Survey publications released prior to the current year are listed in the most recent annual "Price and Availability List." Publications that may be listed in various U.S. Geological Survey catalogs (see back inside cover) but not listed in the most recent annual "Price and Availability List" may no longer be available.

Reports released through the NTIS may be obtained by writing to the National Technical Information Service, U.S. Department of Commerce, Springfield, VA 22161; please include NTIS report number with inquiry.

Order U.S. Geological Survey publications by mail or over the counter from the offices listed below.

\section{BY MAIL}

\section{Books}

Professional Papers, Bulletins, Water-Supply Papers, Techniques of Water-Resources Investigations, Circulars, publications of general interest (such as leaflets, pamphlets, booklets), single copies of Earthquakes \& Volcanoes, Preliminary Determination of Epicenters, and some miscellaneous reports, including some of the foregoing series that have gone out of print at the Superintendent of Documents, are obtainable by mail from

\section{U.S. Geological Survey, Information Services Box 25286, Federal Center Denver, CO 80225}

Subscriptions to periodicals (Earthquakes \& Volcanoes and Preliminary Determination of Epicenters) can be obtained ONLY from the

\section{Superintendent of Documents Government Printing Office Washington, DC 20402} Documents.)

(Check or money order must be payable to Superintendent of Maps

For maps, address mail orders to

\section{U.S. Geological Survey, Information Services Box 25286, Federal Center Denver, CO 80225}

Residents of Alaska may order maps from

\author{
U.S. Geological Survey, Earth Science Information Center \\ 101 Twelfth Ave., Box 12 \\ Fairbanks, AK 99701
}

\section{OVER THE COUNTER}

\section{Books and Maps}

Books and maps of the U.S. Geological Survey are available over the counter at the following U.S. Geological Survey offices, all of which are authorized agents of the Superintendent of Documents.

- ANCHORAGE, Alaska-Rm. 101, 4230 University Dr.

- LAKEWOOD, Colorado-Federal Center, Bldg. 810

- MENLO PARK, California-Bldg. 3, Rm. 3128, 345 Middlefield Rd.

- RESTON, Virginia-USGS National Center, Rm. 1C402, 12201 Sunrise Valley Dr.

- SALT LAKE CITY, Utah-Federal Bldg., Rm. 8105, 125 South State St.

- SPOKANE, Washington-U.S. Post Office Bldg., Rm. 135, West 904 Riverside Ave.

- WASHINGTON, D.C.-Main Interior Bldg., Rm. 2650, 18th and C Sts., NW.

\section{Maps Only}

Maps may be purchased over the counter at the following U.S. Geological Survey offices:

- FAIRBANKS, Alaska-New Federal Bldg, 101 Twelfth Ave.

- ROLLA, Missouri-1400 Independence Rd.

- STENNIS SPACE CENTER, Mississippi-Bldg. 3101 


\section{The Diatom Genus Actinocyclus in the Western United States}

J. Platt Bradbury and William N. Krebs, Editors

A. Actinocyclus (Bacillariophyta) Species from Lacustrine Miocene Deposits of the Western United States

By J. Platt Bradbury and William N. Krebs

B. Geologic Ranges of Lacustrine Actinocyclus Species, Western United States By William N. Krebs and J. Platt Bradbury

U.S. GEOLOGICAL SURVEY PROFESSIONAL PAPER 1543A-B

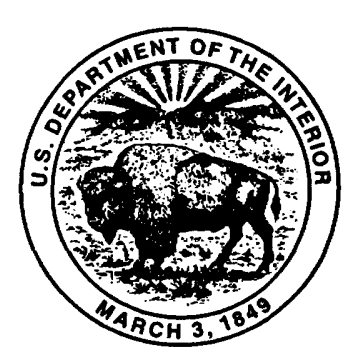

UNITED STATES GOVERNMENT PRINTING OFFICE : 1995 


\title{
U.S. DEPARTMENT OF THE INTERIOR BRUCE BABBITT, Secretary
}

\author{
U.S. GEOLOGICAL SURVEY
}

Robert M. Hirsch, Acting Director

For sale by U.S. Geological Survey, Map Distribution

Box 25286, MS 306, Federal Center

Denver, CO 80225 Any use of trade, product, or firm names in this publication is for descriptive purposes only and
does not imply endorsement by the U.S. Government

\section{Library of Congress Cataloging-in-Publication Data}

The Diatom genus Actinocyclus in the Western United States / J. Platt Bradbury and William N. Krebs, editors.

p. cm.-(U.S. Geological Survey professional paper ; 1543)

Includes bibliographical references

Contents: A. Actinocyclus (Bacillariophyta) species from lacustrine Miocene deposits of the Western United States / by J. Platt Bradbury and William N. Krebs-

B. Geologic ranges of lacustrine Actinocyclus species, Western United States / by William N. Krebs and J. Platt Bradbury.

Supt. of Docs. no.: I19.16:P1543A\&B.

1. Actinocyclus, Fossil-West (U.S.) 2. Paleobotany-Miocene.

II. Krebs, William N. III. Series.

QE955.D53 1993

561'.93-dc20 


\section{CONTENTS}

[Letters designate the chapters]

(A) Actinocyclus (Bacillariophyta) species from lacustrine Miocene deposits of the Western United States, by J. Platt Bradbury and William N. Krebs

(B) Geologic ranges of lacustrine Actinocyclus species, Western United States, by William N. Krebs and J. Platt Bradbury 


\section{Actinocyclus (Bacillariophyta) Species from Lacustrine Miocene Deposits of the Western United States}

By J. Platt Bradbury and William N. Krebs

THE DIATOM GENUS ACTINOCYCLUS IN THE WESTERN UNITED STATES

U.S. GEOLOGICAL SURVEY PROFESSIONAL PAPER 1543-A

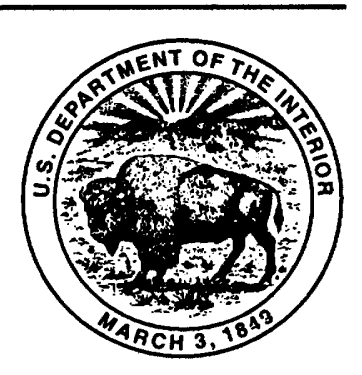

UNITED STATES GOVERNMENT PRINTING OFFICE, WASHINGTON : 1995 


\section{CONTENTS}

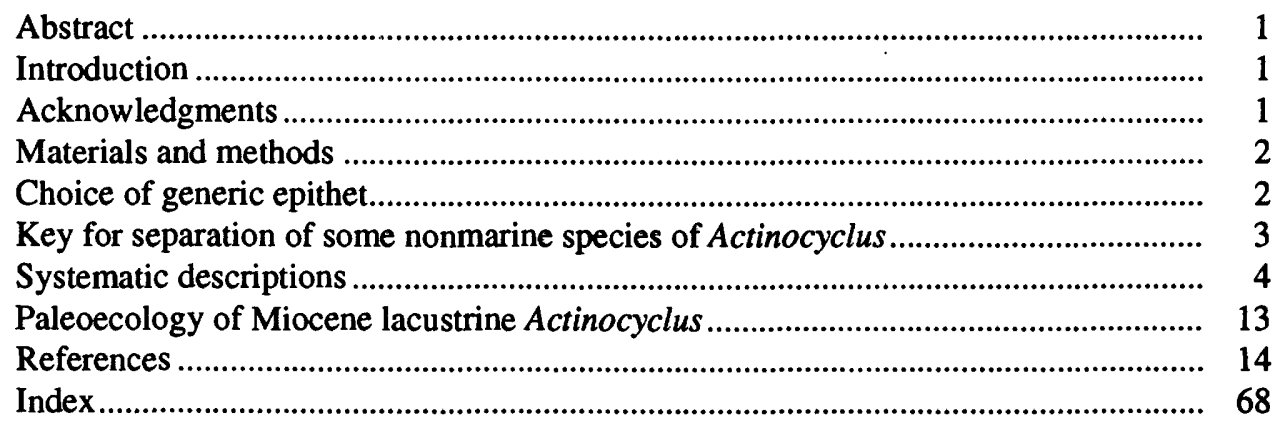

\section{PLATES}

[Plates follow references]

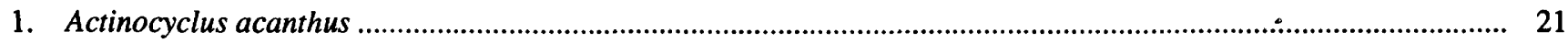

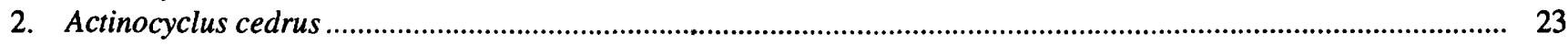

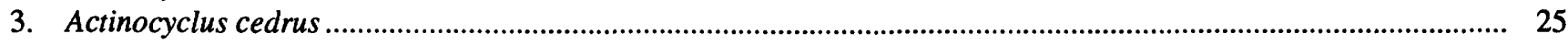

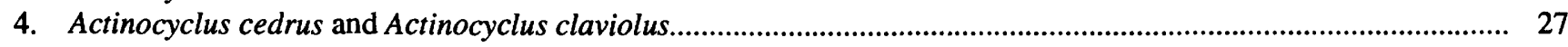

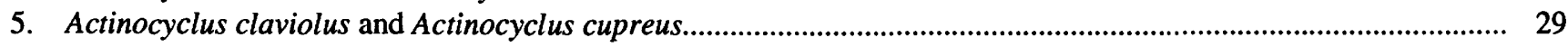

6. Actinocyclus sp. cf. A cupreus and Actinocyclus ehrenbergii ...................................................................... 31

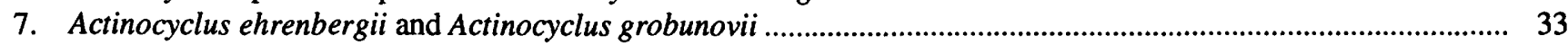

8. Actinocyclus kanitzii, Actinocyclus krasskei, and Actinocyclus tubulosus .......................................................... 35

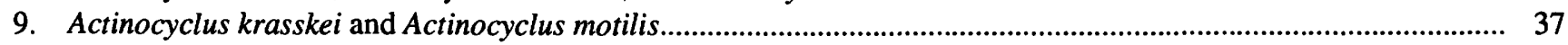

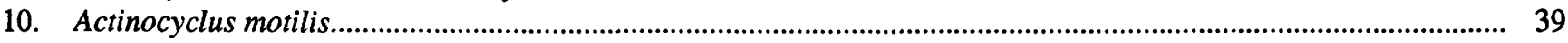

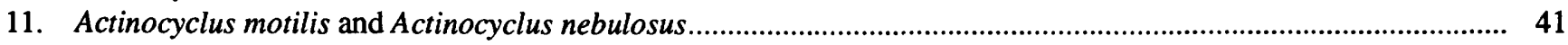

12. Actinocyclus nebulosus, Actinocyclus normanii f. subsalsa, and Actinocyclus pinnulus...................................... 43

13. Actinocyclus pinnulus, Actinocyclus sp. cf. A. pinnulus, and Actinocyclus theleus .............................................. 45

14. Actinocyclus theleus, Coscinodiscus (=Actinocyclus) variabilis, and Actinocyclus venenosus ................................ 47

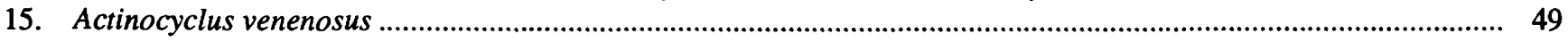




\title{
ACTINOCYCLUS (BACILLARIOPHYTA) SPECIES FROM LACUSTRINE MIOCENE DEPOSITS OF THE WESTERN UNITED STATES
}

\author{
By J. PLATT BRADBURY and WILLIAM N. KREBS
}

\begin{abstract}
Species of the diatom genus Actinocyclus Ehrenberg were important constituents of lacustrine phytoplankton in the Western United States during much of the early and middle Miocene (19-10 Ma). Similar and (or) identical fossil Actinocyclus species are found elsewhere in the world, particularly in Eurasia, in Neogene lacustrine diatomaceous rocks. Ten new species of fossil lacustrine Actinocyclus (A acanthus, A. cedrus, A. claviolus, A. cupreus, A. motilis, A. nebulosus, A. pinnulus, A. theleus, A. venenosus, and Actinocyclus gorbunovii var. fossa) are described and a new name ( $A$. krasskei) is proposed based on the study of samples from 115 localities in the Western United States that range in age from the early Miocene to Pleistocene. Seventy of these localities contain Actinocyclus. Diagnostic characteristics include degree and nature of fasciculation, size of pseudonodule, areolae density, disposition and shape of hyaline stripes on the valve disk and mantle, degree of undulation, diameter, presence and nature of marginal tubular processes and spines, size and shape of areolae, and character of labiate processes.
\end{abstract}

\section{INTRODUCTION}

The diatom genus Actinocyclus characterized openwater lacustrine environments in the Western United States during much of the early and middle Miocene (19-10 Ma). Fossil localities containing Actinocyclus are found in diatomites and diatomaceous shales deposited in paleolake systems of Nevada, Idaho, California, Oregon, and Washington (Krebs and others, 1987). The forms of Actinocyclus found in these deposits resemble those from other parts of the world (for example, Bradbury and Krebs, 1982; Bradbury, 1984; Bradbury and others, 1985), particularly from Eurasia, where a number of distinct taxa have been described. Radiometric dates associated with Actinocyclus occurrences in the
United States suggest that some of the forms have biochronologic value. Preliminary information about the geologic distribution of related taxa in other parts of the world indicates that this group may have potential for use in a worldwide lacustrine diatom biochronology.

This report describes and presents light and scanning electron microscope photographs of several distinctive Actinocyclus species from the Western United States. An artificial key based on characters observable in the light microscope assists separation of these morphologically variable taxa. The key includes a few European taxa, some of which also appear in the United States, and two modern nearshore marine species that can live in limnic environments. One of these species, Actinocyclus normanii f. subsalsa (pl. 12, figs. 2-5), lives today in the Great Lakes and has been recovered from late Holocene sediments of Lake Ontario (Stoermer and others, 1985).

The appropriate morphological characters for taxonomic separation of Actinocyclus are still largely unknown. The variability of surface areolae patterns (for example, fasciculation), degree of undulation, and mantle characteristics is great in these centric diatoms, and may be environmentally controlled to some degree (Theriot and Stoermer, 1984). Study of smaller structures, such as labiate processes, external processes and pseudonodules, and their morphometric relationships may be required to understand the natural classification of these diatoms. We do not resolve these questions, but we do present guidelines for the consistent description and identification of Actinocyclus species applicable to biostratigraphy and paleoecology.

\section{ACKNOWLEDGMENTS}

We particularly acknowledge the efforts of Kathryn Dieterich-Rurup in securing scanning electron microscope photographs of the Actinocyclus species illustrated in the accompanying plates. Horst Lange-Bertalot photographed 
Krasske's type material of Coscinodiscus (Actinocyclus) miocenicus and $C$. $(=A$.) variabilis. E.C. Theriot, Reimer Simonsen, Simone Servant-Vildary, and G.K. Khursevich have all provided many helpful discussions and insights into the morphological variations and taxonomic-descriptive problems with Actinocyclus. Simone Servant-Vildary, Rainer Gersonde, S.W. Starratt, L.H. Burckle, and Fumio Akiba kindly supplied comparative material. J.A. Barron and Elisabeth Fourtanier reviewed the manuscript and provided many useful suggestions. We thank all these individuals for their interest in this study.

\section{MATERIALS AND METHODS}

Diatomites, diatomaceous tuffs, and lacustrine shales have been sampled from outcrops and wells in the Western United States. The locality numbers referred to in the text refer to these sites whose age (if known) and locations are given in Appendix 1 and figure 2 of Krebs and Bradbury (Chapter B).

To minimize contamination by water and airborne diatoms (Sovereign, 1963), outcrops were cleaned in the field to a depth of about $5 \mathrm{~cm}$ during sampling, and material representing $1-5 \mathrm{~cm}$ of stratigraphic thickness was removed and placed in air-tight plastic bags. About $1 \mathrm{cc}$ of diatomaceous sediment, with all surfaces cleaned a second time, was disaggregated in distilled water and boiled in concentrated nitric acid. The samples, once rinsed of all traces of acid, were mounted in Hyrax $(n=1.60)$. Observations for species descriptions were made with a compound microscope (LM) at appropriate magnifications.

An aliquot of the diatom preparation was settled on a scanning electron microscope (SEM) stub and sputtercoated with gold/palladium. SEM photographs of selected specimens were taken with a JEOL $35 \mathrm{C}$ scanning electron microscope. In general, internal surfaces of diatoms are better preserved than external surfaces (Bradbury, 1984), but where appropriate, SEM documentation of both sides of the diatom was made to illustrate external characteristics necessary for identification. Type and LM-figured specimens are located on designated $2.54 \times 7.62 \mathrm{~cm}$ microscope slides by England Finder (E.F.) coordinates.

\section{CHOICE OF GENERIC EPITHET}

\section{Coscinodiscus, Cestodiscus, Stephanodiscus, Pontodis-} cus, and Actinocyclus have all been used as generic epithets for fossil lacustrine centric diatoms that possess a marginal ring of laterally expanded (fan-shaped) labiate processes and radial-fasciculate areolation (for example, Krasske, 1934; Lohman, 1957; Hajós, 1970; Temniskova-Topalova and others, 1981; Bradbury, 1984). The very close similarity of Pontodiscus and Cestodiscus (Radionova, 1987) suggests that some of these names might be synonymous.

Bradbury (1984) confirmed the presence of a pseudonodule on Neogene lacustrine centric diatoms from Idaho and China supporting their inclusion in the genus Actinocyclus (see also, Simonsen, 1975). Nevertheless, in some marine species of Actinocyclus, the pseudonodule is tiny and difficult to distinguish from a normal areola (Watkins and Fryxell, 1986), and Radionova (1987) maintained that Cestodiscus may or may not have a pseudonodule. She distinguished this genus from Actinocyclus by the form of the labiate process (mushroom-shaped in Cestodiscus and nozzle-shaped in Actinocyclus) and by the character of the velum covering the areolae (star-shaped perforations in Cestodiscus and sieve-like openings in Actinocyclus) (Radionova, 1987). Marginal hyaline stripes of unadorned silica, positioned above and around the openings of the labiate processes characterize many Cestodiscus species (Radionova, 1987), but these structures are also present on diatoms referred to Actinocyclus (Simonsen, 1982).

The choice of the generic epithet for these centric diatoms clearly depends upon whether expanded or restricted generic definitions are employed. SEM examination of representatives of type species may suggest the synonymy of some genera. Labiate process morphology in nonmarine diatoms of the family Hemidiscaceae is variable and easily altered by corrosion in fossil forms. Pseudonodules may be obscured by debris or overgrowths of silica and clay minerals, further complicating the use of these structures for generic classification. At this time, there is no compelling reason to use the name Cestodiscus for these otherwise clearly Actinocyclus-like diatoms, and the latter name is retained for this study. Coscinodiscus appears to be genuinely different (as shown by Radionova, 1987), although it is still not properly typified, and at least some Pontodiscus species have been incorporated into Actinocyclus (Khursevich and others, 1990).

The species of Actinocyclus described in this report have been separated by more or less obvious, if variable, morphological differences. It can be argued (compare Mann, 1988) that each paleolake contained its own Actinocyclus species, particularly when such paleolake systems were temporally separated by hundreds of thousands or millions of years. Such great temporal and geographic separation with concomitant differences in climate, geology, hydrology, and ecology reduce the likelihood of potential biological interaction between individuals of Actinocyclus despite their morphological similarity. Nevertheless, the morphological units described here are moderately consistent and at least imply similar environmental controls on Actinocyclus that can be meaningful for biostratigraphic and paleoecologic ends. 


\section{KEY FOR SEPARATION OF SOME NONMARINE SPECIES OF ACTINOCYCLUS}

The following key organizes the characters of the nonmarine species of Actinocyclus described in this report and a few others described elsewhere to facilitate their separation and identification. The species of Actinocyclus are quite variable, yet morphologically similar, and examination of a moderately large series of specimens is required to obtain an appreciation of the variation and a general sense of their structural characteristics. Even so, intermediate forms often occur that defy simple classification. Specimens at the very large and very small ends of the size spectrum may be difficult to sort out with this key.

A. Fasciculate: clearly defined sectors of areolae rows.

B. Fascicles marked off only by radial rows of areolae.

C. Pseudonodule large, conspicuous; areolae on marginal $1 / 3$ of disk in more or less regular tangential rows; often in brackish water. Actinocyclus ehrenbergii Ralfs, (pl. 6, fig. 3).

C. Pseudonodule tiny, difficult or impossible to see in LM, especially in heavily silicified individuals; areolae on marginal $1 / 3$ of disk in undulating, disorganized rows. Areolae within fascicles parallel. Actinocyclus nebulosus, (pl. 11, figs. 3, 4).

C. Pseudonodule small, but generally visible in LM. Marginal areolae not in widely spaced undulating rows. Areolae within fascicles subparallel/ subradial. Actinocyclus cupreus, (pl. 5, figs. 6, 7)

B. Fascicles marked off by a combination of radial rows of areolae and (or) comparatively long, hyaline stripes originating at labiate process exit pore near disk/mantle juncture.

C. Hyaline stripes extending about $1 / 3$ the distance toward the valve center and continuing in a radial row of areolae (see Frenguelli, 1928; Krasske, 1934). Coscinodiscus (=Actinocyclus) variabilis (sensu Krasske, 1934), (pl. 14, figs. $5,6)$.

C. Fascicles marked off only by long hyaline stripes that extend nearly to the valve center (see Schauderna, 1983). Actinocyclus kanitzii (Pant. and Grun.) Schauderna, (pl. 8, fig. 1).

C. Fascicles marked off by pyriform or cloveshaped hyaline stripes with narrow, pointed ends that extend a short distance towards the valve center; the remaining fascicle boundary composed of a radial row of areolae. Actinocyclus claviolus, (pl. 5, figs. 1, 2).
B. Fascicles marked off only by directional incongruity between adjacent sets of subparallel areolae rows. Hyaline stripes absent (see Hasle, 1977). Actinocyclus normanii (Juhl.-Dannf.) Hustedt, (pl. 12, figs. 2, 3).

A. Nonfasciculate: no clear sectors or fascicles of areolae, or fascicles irregularly formed, difficult to define or highly variable on specimens of different size. Hyaline stripes mark location of labiate processes.

B. $>12$ areolae $/ 10 \mu \mathrm{m}$ (usually $14-18$ ).

C. Marginal processes present, located on the exit pore of labiate process.

D. Marginal processes conspicuous.

E. Marginal processes narrow tubes with lateral, fin-like projections. Actinocyclus pinnulus, (pl. 13, fig. 1).

E. Marginal processes are broad, irregularly forked tubes 1-2 $\mu \mathrm{m}$ long. Actinocyclus nordlingensis Schauderna, (not figured).

E. Marginal process usually angled, unforked rather broad tubes, occasionally adorned with lateral spines. Actinocyclus acanthus, (pl. 1, fig. 3).

D. Marginal processes inconspicuous.

E. Marginal process is a low, small, shieldlike bump or nipple; often difficult to observe, fine areolation, 13-18 areolae/ $10 \mu \mathrm{m}$, diameter typically $<30 \mu \mathrm{m}$. Actinocyclus theleus, (pl. 14, fig. 1).

E. Marginal processes slender, unornamented tubes on hyaline stripes. Actinocyclus tubulosus (pl. 8, fig.7) Khursevich (Khursevich and others, 1990).

C. Marginal processes at labiate process exit pore absent.

D. Diameter 20-70 $\mu \mathrm{m}$, valve conspicuously undulate, weakly undulate, or flat, areolae generally $\quad 12-13 / 10 \mu \mathrm{m}$. Actinocyclus krasskei (Krasske), (pl. 8, figs. 2-8).

E. Valve conspicuously undulate, often $>50$ $\mu \mathrm{m}$ in diameter. Actinocyclus krasskei (undulate form), (pl. 8, fig. 5).

E. Valve flat or weakly undulate, diameter typically $<50 \mu \mathrm{m}$. Actinocyclus krasskei (pl. 8, fig. 2).

D. Diameter $30-70 \mu \mathrm{m}$, valve conspicuously undulate, areolae 14-18/10 $\mu \mathrm{m}$. A "moat" surrounds the pseudonodule. Actinocyclus gorbunovii var. fossa, (pl. 7, fig. 3).

B. $<12$ areolae $/ 10 \mu \mathrm{m}$

C. Areolae large $(1+\mu \mathrm{m})$, closely packed, typically $7-10 / 10 \mu \mathrm{m}$, polygonal in outline. 
D. Conspicuous, generally pointed hyaline stripes enclosing exit pore and extending onto the valve disk. Actinocyclus venenosus, (pl. 15, fig. 1).

D. Generally inconspicuous hyaline stripes that end near the valve/mantle juncture. Spines may or may not be present at disk/mantle junction. Actinocyclus cedrus (pl. 2, fig. 1) and A. cedrus spinose form (pl. 4, fig. 4).

C. Areolae smaller, circular in outline and typically loosely packed. Marginal areolae rows sinuous and interdigitating. Actinocyclus motilis, (pl. 9, figs. 4-6).

\section{SYSTEMATIC DESCRIPTIONS}

\section{ACTINOCYCLUS ACANTHUS \\ Bradbury \& Krebs sp. nov.}

\author{
Plate 1, figures 1-9
}

Description.-Valve circular, shallowly concave with slightly raised margin. Diameter typically ranging from 30 to $100 \mu \mathrm{m}$. Disk with round areolae arranged in non-fasciculate, radial rows; 9-14 areolae/10 $\mu \mathrm{m}$. Valve center of larger specimens sometimes hyaline, containing only scattered areolae. Small, often obscure, radial, marginal hyaline stripes at disk-mantle juncture mark positions of labiate processes and are adorned with stout, hollow tubules up to $2 \mu \mathrm{m}$ in length that may bear terminal lateral spines. Tubule stems either rounded or angled (often triangular) in cross-section (pl. 1, fig. 7). Because of breakage, morphological characteristics of tubule ends seldom visible. Valve mantle finely areolate $(20 / 10 \mu \mathrm{m})$ and steeply sloping away from disk margin. Labiate processes short, narrow-stemmed, with broad, spade-shaped labiae. Pseudonodule small, about $1 \mu \mathrm{m}$ in diameter, and variably located between labiate processes near valve margin.

Variability.-The length of hyaline stripes appears to vary among individuals both within and between localities. In an unnamed unit at New Pass, Lander County, Nevada (loc. 42) and in the Esmeralda Formation (Miocene) at Cedar Mountain, Nye County, Nevada (loc. 74), the hyaline stripes are often very small and obscure (pl. 1, fig. 6). Specimens from the Bully Creek Formation (Miocene), Malheur County, Oregon (loc. 7) have longer hyaline stripes (2-3 $\mu \mathrm{m}$ or longer), as do occasional specimens from the Cedar Mountain section (Lohman, 1957).

The hyaline central area is largest and best developed in specimens from the Cedar Mountain section, while in material from New Pass it is smaller or absent. Pseudonodule position also seems to vary. In New Pass and Cedar Mountain (Esmeralda Formation) specimens, it is small and closely adjacent to a labiate process, while in the Bully Creek Formation material, it is located about $1 / 3$ the distance between two labiate processes.

Because of their susceptibility to abrasion and corrosion, the external tubules of this species are often poorly preserved or incomplete. In material from New Pass, some appear to bifurcate or are adorned with short lateral spines or flanges, suggesting that the typically short, blunt tubes often seen in LM may be artifacts of preservation. Tubules vary in cross section, being either round, triangular, or elliptical, but it is not known how constant tubules are on a single specimen from our available material.

The apiculate species of Actinocyclus from other localities are close to the type in appearance, but not identical. Detailed study, including morphometric analysis, may require splitting this apiculate Actinocyclus group into several species.

Diagnosis.-Actinocyclus acanthus can be distinguished from other lacustrine members of the genus by the presence of robust, often angled, hollow thorn-like tubes on the hyaline stripes that mark the exit pores of labiate processes. A. gorbunovii is more finely areolate, and external tubules are absent. Actinocyclus nordlingensis Schauderna has forked tubes and is more finely areolate $(14-20 / 10 \mu \mathrm{m})$. Its labiate processes are narrow-stemmed but comparatively long $(>2 \mu \mathrm{m})$. The pseudonodule location in A. nordlingensis is located about $1 / 3$ the distance between adjacent labiate processes (Schauderna, 1983). Carina-like spines may be present on Actinocyclus cedrus, but they are irregularly placed, apparently solid, and not necessarily located on the hyaline stripes. Actinocyclus tubulosus Khursevich is smaller (16-34 $\mu \mathrm{m}$ diameter), has more densely packed areolae $(16-22 / 10 \mu \mathrm{m})$, and external tubes with a rounded cross section. A. cedrus has coarse, polygonal areolae. Actinocyclus pinnulus is similar to $A$. acanthus, but has distinctly finned tubules, is clearly fasciculate, and has long, narrow hyaline stripes.

Types.-Holotype: Strew slide United States National Museum (USNM) \#465534. specimen located at E.F. (England Finder) H46.

Isotypes: Strew slides in the following institutions: Academy of Natural Sciences of Philadelphia (ANSP) A-G.C. \#64465; U.S. Geological Survey, Denver (USGS-D) \#14 VII 85-4; California Academy of Sciences (CAS) \#216051.

Type Locality.-Because the diatom is best preserved and most abundant in unnamed deposits near New Pass, Lander County, Nevada (loc. 42 = USGS Denver 14 VII 85-4), this site has been selected as the type locality.

Remarks.-The specific epithet "acanthus" (L. thorn) refers to the presence of hollow, thorn-like tubes at the labiate process exit pores.

Actinocyclus acanthus has also been found in the Bully Creek Formation, Harper Basin, Malheur County, Oregon, and in the Esmeralda Formation near Cedar Mountain, Nye County, Nevada (loc. 74). Here the taxon was originally described by Lohman (1957) as Cestodiscus apiculatus nomen nudum. At the Cedar Mountain section, Actinocyclus acanthus is associated with species of Surirella, Anomoeoneis, and Pinnularia (Lohman, 1957), whose modern 
relatives suggest deposition in moderately saline, alkaline water. At some levels in the New Pass locality, it is associated with Chaetoceros, also suggesting saline water, but elsewhere at New Pass, and at Bully Creek, freshwater species of Aulacoseira dominate the samples. At Silvies Valley, Grant County, Oregon (loc. 75), Actinocyclus acanthus is associated with large numbers of Fragilaria sp. cf. F. virescens. Other diatoms present include Aulacoseira, Tetracyclus, Tabellaria, Eunotia, and Achnanthes. Perhaps the morphological differences seen in Actinocyclus acanthus reflect salinity or other environmental characteristics.

\section{ACTINOCYCLUS CEDRUS Bradbury \& Krebs sp. nov.}

Plate 2, figures 1-7; plate 3, figures 1-8; plate 4, figures 1-6

Description.-Valve circular, with slightly raised margin. Diameter typically $50-100 \mu \mathrm{m}$, but ranging from 20 to $>150 \mu \mathrm{m}$. Valve face shallowly concave to weakly concentrically undulate with radial rows of large ( $1 \mu \mathrm{m}$ diameter $)$, polygonal-shaped areolae, ranging from 6-10/10 $\mu \mathrm{m}$. Vague fasciculation of valve disk caused by bundles of inutually parallel areolae rows that extend variable distances towards the valve center progressively truncating one another (pl. 3, fig. 2). Valve center typically densely packed with areolae. Small, generally short, hyaline stripes at valve mantle junction barely extend over mantle to enclose large $(1 \mu \mathrm{m}$ diameter) exit pores of labiate processes. Labiate processes 3-5 $\mu \mathrm{m}$ tall, with narrow, round or oval stems and relatively broad, spade-shaped labiae. Disk/mantle margin often hyaline and irregularly areolate and (or) variably ornamented with solid, granule-, keel-, or spine-like protuberances. Mantle variably high $(10-15 \mu \mathrm{m})$, and nearly perpendicular to valve face plane, with vertical areolae rows, 16 areolae/10 $\mu \mathrm{m}$. Pseudonodule small and variably located between labiate processes, generally closer to one.

Variability.-The disk/mantle juncture may or may not be hyaline and irregularly areolate, or ornamented with spine- or granule-like protuberances. Such ornamentation is more typical in specimens from the Turner Creek (Pit River) locality in Modoc County, California (loc. 17) (pl. 4, figs. 4-6), and less common at the type locality in Stewart Valley, Mineral County, Nevada (loc. 20). Areolae near the valve disk center are sometimes sparse and surrounded by hyaline silica. Fasciculation is more apparent in some specimens than others. For example, specimens from the Virginia Range, $16 \mathrm{~km}$ north of Virginia City, Storey County, Nevada (loc. 68), are not clearly fasciculate, although they conform to the species in other features. Size of the hyaline stripes varies to some degree among specimens from different sites and may represent temporal or environmental gradations within this species. Forms of this species from deposits correlated to the Aldrich Station Formation (Miocene), Lyon County, Nevada (loc. 1), and from deposits near Drewsey, Harney County, Oregon (loc. 63), tend to be less fasciculate than the type and are typically spinose. The labiate processes are taller and thinner in specimens from Goose Creek, Baker County, Oregon (loc. 27).

Diagnosis.-Actinocyclus cedrus is very similar to $A$. venenosus, another nonmarine, fossil Actinocyclus species with coarse, polygonal areolation on the valve face. Actinocyclus venenosus is characterized by generally longer and more prominent hyaline stripes that extend well onto the valve disk. A. cedrus tends to be more obviously, if irregularly, fasciculate than $A$. venenosus, and concentric undulation is usually poorly developed in A. cedrus.

Types.-Holotype: Strew slide USNM \#465535, specimen located at E.F. L38/1.

Isotypes: Strew slides ANSP A-G.C. \#64466; CAS \#216052; USGS-D \#31:I:88-1(65).

Type Locality.-“Diatomite Ridge” in Stewart Valley, northwest of Cedar Mountain, Mineral County, Nevada (loc. 20 = USGS Denver 31 I 88-1 [65]) has been selected as the type locality for Actinocyclus cedrus. The collection site is located at $38.62^{\circ} \mathrm{N}$., $117.94^{\circ} \mathrm{W}$., about $8 \mathrm{~m}$ below the top of a 40-m section of buff, thin-bedded to laminated diatomaceous shales, and about $28 \mathrm{~m}$ above a volcanic ash dated at $15.1 \mathrm{Ma}$ (S.W. Starratt, written commun., 1986). The section has been assigned to the Esmeralda Formation.

Remarks.-The specific epithet "cedrus" (L. cedar) refers to the type locality of this species near Cedar Mountain. The type material was collected by S.W. Starratt and represents his sample DR-65. Lohman (1957) identified this diatom by the name Cestodiscus cedarensis nomen nudum at a nearby locality on the southeast flank of Cedar Mountain. The same (or very similar) species is reported from the Otis Basin, Harney County, Oregon (VanLandingham, 1967) under the name Coscinodiscus subtilis.

Associated diatoms at the type locality include freshwater, benthic Fragilaria species, Ellerbeckia arenaria v. teres, Tetracyclus sp., and a dominance of planktonic Aulacoseira spp.

\section{ACTINOCYCLUS CLAVIOLUS \\ Bradbury \& Krebs sp. nov.}

Plate 4, figure 7; plate 5, figures $1-5$

Description.-Valve circular, nearly flat with a slightly raised or depressed center. Diameter ranging between 17 and about $60 \mu \mathrm{m}$, typically about 27-30 $\mu \mathrm{m}$. Areolae about 13-14/10 $\mu \mathrm{m}$, small, round and in subparallel to radial rows. Areolae rows grouped into fascicles set off by continuous rows of areolae originating from hyaline stripe of each labiate process and running to valve center. Valve center sometimes a small, irregular hyaline area. Hyaline stripes marking locations of labiate processes comparatively long (3-7 $\mu \mathrm{m})$, narrowed, or pointed proximally and expanded distally to form irregular, somewhat triangular-, cross- or clove-shaped areas (pl. 5, figs. 1-3). External 
expression of labiate process is a short, blunt, rather thickwalled tube with a narrow opening rising 1-2 $\mu \mathrm{m}$ above disk/mantle junction (pl. 5, fig. 3). Valve mantle steeply sloping away from disk, finely areolate (about $26 / 10 \mu \mathrm{m}$ ) and fairly short. Labiate processes not observed, but presumably with narrow, round stems. Pseudonodule of medium size (1-2 $\mu \mathrm{m}$ in diameter) and often easily visible between hyaline stripes (pl. 5, figs. 2, 4, 5).

Variability.-Actinocyclus claviolus is known only from Jungle Point, Idaho County, Idaho (loc. 33). At this locality, large specimens have fascicles with radial areolae rows. Consequently, the radial row associated with the hyaline stripe is less distinctive. Small specimens have fascicles in which the areolae rows are parallel to the central areolae row or in irregular groups of subparallel rows. The hyaline stripes are irregular but always somewhat pyriform or crossshaped. Larger specimens have proportionally longer stripes. The central hyaline area is typically irregular, but always small.

Diagnosis.-Actinocyclus claviolus is morphologically similar to A. cupreus, but it can be distinguished by its thick, prominent hyaline stripes, generally smaller size, and the presence of thick external tubes over the labiate process pore. Like $A$. cupreus, $A$. claviolus is also morphologically close to Coscinodiscus (=Actinocyclus) variabilis (sensu Krasske 1934) (pl. 14, figs. 5, 6), but that species does not have laterally expanded hyaline stripes and is more coarsely areolate than $A$. claviolus. In addition, the hyaline stripes of Coscinodiscus variabilis (sensu Krasske) are typically longer, extending to about $1 / 3$ of the disk radius.

Types.-Holotype: Strew slide USNM \#465536, specimen at E.F. R28/2.

Isotypes: Strew slides ANSP A-G.C. \#64467; USGS-D \#5 XII 80-7; CAS \#216053.

Type Locality.-The type locality of Actinocyclus claviolus is an unnamed lacustrine deposit at Jungle Point, northwest of the town of Lowell, Idaho County, ldaho; $S E 1 / 4, S E 1 / 4$ sec. 15 , T. 33 N., R. 6 E. (loc. $33=$ USGS Denver 5 XIl 80-7). The diatoms at this locality show some corrosion and breakage.

Remarks.-The specific epithet "claviolus" (L. diminutive for nail or clove) refers to the small clove-like shape of the hyaline stripes of this species. Aulacoseira sp. cf. A. praeislandica is the dominant diatom associated with Actinocyclus claviolus.

\section{ACTINOCYCLUS CUPREUS \\ Bradbury \& Krebs sp. nov.}

Plate 5, figures 6-9

Description.-Valve circular, shallowly concave with a broadly raised margin. Diameter typically around $50 \mu \mathrm{m}$ and ranging between 20 and $76 \mu \mathrm{m}$. Areolae roundpolygonal, in roughly radial to parallel rows. Areolae rows grouped in broad fascicles set off by continuous rows of areolae originating from hyaline stripe of each labiate process and running to valve center. Areolae about $13 / 10 \mu \mathrm{m}$, generally loosely packed near valve center. Comparatively long $(2-5 \mu \mathrm{m})$, prominent hyaline stripes extend from exit pore of labiate processes over disk/mantle junction and onto disk. Valve mantle finely areolate (about $20 / 10 \mu \mathrm{m}$ ) and gently sloping away from valve disk. Labiate processes with narrow, round stems and rather broad, spade-like labiae. Pseudonodule small, but usually clearly visible; located at a variable distance between labiate processes on disk-mantle junction.

Variability.-To date, Actinocyclus cupreus has been found at four localities in the Western United States. At Copper Kettle Canyon, Churchill County, Nevada (loc. 16), evident variability has been found in the degree of fasciculation. Small specimens, probably referable to this species, tend to be more coarsely areolate and do not clearly show the radial areolae rows running between the hyaline stripes and the valve center that separate the areolae fascicles. In large specimens, strong valve undulation may obscure the radial areolae rows that border fascicles. Between labiate processes, areolae rows become more radial than mutually parallel in small individuals. Hyaline stripes show some variation in length, with relatively longer stripes on larger specimens. At Juliaetta, Nez Perce County, Idaho (loc. 32), and at Jungle Point, Idaho County, ldaho (loc. 33), diatoms referable to A. cupreus are comparatively small and resemble $A$. claviolus and A. krasskei, respectively, although the distinctive fasciculation is evident. In the Miocene Humboldt Formation, Eureka County, Nevada (loc. 30), comparatively large forms are present that closely resemble the Copper Kettle Canyon material.

Diagnosis.-Actinocyclus cupreus is distinguished from $A$. ehrenbergii (which also has single, radial areolae rows between hyaline stripes and the valve center) by its inconspicuous small pseudonodule, finer areolation, and generally smaller size. See also diagnosis under $A$. nebulosus and $A$. claviolus.

Actinocyclus cupreus is also similar to an Actinocyclus species identified as Coscinodiscus variabilis Frenguelli by Krasske (1934) from Miocene freshwater deposits near the town of Ruckers on the southeast margin of the Vogelsberg Range at the northern end of the Rhine graben in central Germany. The Ruckers material tends to have slightly coarser areolation (9-12 areolae $/ 10 \mu \mathrm{m})$ than do specimens from Copper Kettle Canyon, and the hyaline stripes are longer, often extending to one half the valve radius. Also, $C$. variabilis appears to have an external extension associated with each pore of the labiate process, unlike A. cupreus. Pseudonodules are visible on well-preserved valves of the Ruckers material indicating their probable affiliation with Actinocyclus.

Types.-Holotype: Strew slide USNM \#465537, E.F. F46/4. 
Isotypes: Strew slides ANSP A-G.C. \#64468; USGS-D \#15 XII 88-1F; CAS \#216054.

Type Locality.-The type locality of Actinocyclus cupreus is an unnamed formation at Copper Kettle Canyon in the northern Stillwater Mountains, sec. 26, T. 24 N., R. 34 E., Churchill County, Nevada (loc. 16 = USGS Denver 15 XII 88-1F). Specimens of A. cupreus are uncommon and poorly preserved.

Remarks.-The specific epithet "cupreus" (L. of copper) refers to the type locality in Copper Kettle Canyon. A similar, perhaps closely related species of Actinocyclus has been found in Miocene freshwater sediments now covered by the Sea of Japan in the region of Yamato Bank (pl. 6, figs. 1, 2) (Burckle and Akiba, 1978; Tsoy and others, 1985), and from Japan (Koizumi, 1988). Specimens from Yamato Bank have hyaline stripes that can be very long, in some cases extending more than halfway towards the valve center in large individuals. The valve disk of this diatom is flatter than in A. cupreus, and the parallel-rowed fasciculation pattern is more regular and distinct. Further studies may confirm that all these diatoms are closely related.

Freshwater, planktonic species of Aulacoseira dominate the type material containing Actinocyclus cupreus; Pinnularia, Tetracyclus, and Fragilaria are present in smaller numbers.

\section{ACTINOCYCLUS EHRENBERGII}

\section{Ralfs in Pritchard (1861)}

Plate 6, figures 3-9; plate 7, figures. 1, 2

Description.-Descriptions, figures, and diagnoses of Actinocyclus ehrenbergii from nearshore marine localities (such as in Hustedt, 1930) suffice to identify and separate this distinctive diatom from nonmarine species of Actinocyclus. The chief characteristic is the large, well defined, annulate-operculate pseudonodule of $A$. ehrenbergii. In addition, marine examples of this species have numerous, close-spaced, short-stemmed labiate processes. In contrast, nonmarine Actinocyclus species appear to have small, nonannulate (but perhaps also operculate?) pseudonodules and typically few and wide-spaced labiate processes with relatively longer stems.

Remarks.-Actinocyclus ehrenbergii (pl. 6, figs. 3-5) is present in upper Miocene continental deposits of the Quiburis Formation, Edgar Canyon, Pima County, Arizona (loc. 92), where it is associated with brackish-water diatoms, such as Hyalodiscus sp. cf. H. laevis, Melosira moniliformis, Diploneis interrupta, D. ovalis, Mastogloia braunii, $M$. elliptica, Frustulia interposita, species of Amphora, Nitzschia, Achnanthes, Navicula, and many others. Benthic alkaline-water diatoms, such as Fragilaria brevistriata, Denticula elegans, and Caloneis silicula, are also abundant and indicate a transitional brackish, perhaps estuarine (Blake, 1902), to freshwater environment. A. ehrenbergii is also present in the uppermost Miocene to lowermost Pliocene Furnace Creek Formation of Death Valley, Inyo County, California (loc. 113).

\section{ACTINOCYCLUS GORBUNOVII var. FOSSA}

Bradbury \& Krebs var. nov.

Plate 7, figures 3-8

Description.-Valve face characterized by comparatively small, round areolae $(14-18 / 10 \mu \mathrm{m})$ arranged in a radial, generally non-fasciculate pattern. Valve diameter averages about $30 \mu \mathrm{m}$ but varies between 15 and $48 \mu \mathrm{m}$. Valve disks typically strongly undulate. Labiate processes with narrow, long stems and circular cross sections. Short $(4 \mu \mathrm{m})$ hyaline stripes extend from external opening of labiate process at valve margin towards valve center. Pseudonodule comparatively distinct, located between labiate processes, and usually closer to one. A tiny, moat-like structure surrounds external opening of pseudonodule (pl. 7, figs. 5-6). In favorable cases, this structure can be seen by LM as a small ring of hyaline silica around pseudonodule pore.

Variability.-Actinocyclus gorbunovii var. fossa is known from only one locality. Some variation in the degree of areolation is present in the center of the valve disk. In large individuals, areolae may be loosely scattered about the valve center. Large valves tend to be more conspicuously undulate than small valves. Not enough SEM observations have been made to determine the constancy of the moat-like structure surrounding the external opening of the pseudonodule. From light microscope observations, it appears to be better developed in some valves than in others.

Diagnosis.-Actinocyclus gorbunovii var. fossa is distinguished from $A$. gorbunovii by the presence of a small moat-like structure of hyal ine silicathat surrounds the external opening of the pseudonodule. This structure is not present in type material of Actinocyclus gorbunovii (G.K. Khursevich, written commun., 1990). The closely spaced areolae (14-18/ $10 \mu \mathrm{m}$ ) and the strongly undulate valve disk, however, suggest a varietal affinity with Actinocyclus gorbunovii.

Actinocyclus krasskei is generally more coarsely areolate $(12-13 / 10 \mu \mathrm{m}$, although finer forms are reported), smaller, and flatter than $A$. gorbunovii var. fossa. Nevertheless, considerable variation exists, and some overlap is found in all these characters. Separation of these species is not likely to be consistent in mixed assemblages, and it may turn out that they all belong to the same variable taxon. N33/1.

Types.-Holotype: Strew slide USNM \#465538, E.F.

Isotypes: Strew slides ANSP A-G.C. \#64775; USGS-D \#2 IX 87-3B; CAS \#216081.

Type Locality.-Actinocyclus gorbunovii var. fossa is common in the early middle Miocene leaf-bearing 
diatomites at Forty-nine Camp, Washoe County, Nevada (loc. 69). Preservation is variable, and valves are often broken.

Remarks.-The varietal epithet "fossa" (L. "ditch") refers to the small ditch or moat surrounding the pseudonodule of this taxon. In the upper Cedarville Formation at Fortynine Camp, Washoe County, Nevada, Actinocyclus gorbunovii var. fossa is associated with abundant Aulacoseira sp. cf. A. islandica. Tetracyclus ellipticus, Ellerbeckia arenaria $\mathrm{v}$. teres, and several other freshwater diatoms are present in smaller numbers.

Bradbury (1984) suggested that Coscinodiscus gorbunovii (Sheshukova-Poretzkaja and Moissejeva, 1964), belonged in the genus Actinocyclus according to its general morphology and the presence of a pseudonodule in a related species from the Poison Creek Formation (Miocene) in the Snake River Plain, Idaho. Khursevich and others (1990) formally transferred $C$. gorbunovii to Actinocyclus. The Poison Creek Formation taxon is now regarded as distinct from A. gorbunovii and has herein been described as Actinocyclus venenosus. In view of the biostratigraphic importance of $A$. gorbunovii in Eurasia and of closely related taxa in the Western United States, it is appropriate to evaluate the original description of Coscinodiscus gorbunovii Shesh. and its varieties.

The following description of Coscinodiscus gorbunovii represents an approximate translation from Russian (Sheshukova-Poretzkaja and Moissejeva, 1964). The original description includes two varieties, Coscinodiscus gorbunovii v. gorbunovii Shesh. and C. gorbunovii v. ethmodiscoidus Moiss.

\section{COSCINODISCUS GORBUNOVII SHESHUKOVA}

In Sheshukova-Poretzkaja \& Moissejeva 1964,

$$
\text { P. 94, pl. 2, figs. 1-5. }
$$

Description.-Cells of yellow-brown color, short cylindrical or disk-shaped, with or without intercalary bands, $30-70 \mu \mathrm{m}$ in diameter, $2-20 \mu \mathrm{m}$ tall. Valves concentrically undulate with a single concave zone and concave center. Valve structure of small, dense areolae in radial rows, $12-18 / 10 \mu \mathrm{m}$, not forming fascicles. Central area small, round or of irregular shape with one or several isolated areolae, or occasionally absent. Distinct undulating rows of areolae occur at the valve margin, and a ring of 7-14 short, blunt spines (=tubules) from which short, radial, hyaline rays emanate towards the valve center. Valve mantle edge narrow, delicately crosshatched (23-24 striae/10 $\mu \mathrm{m}$ or not visible). Short-cylindrical cells have valves with clearly expressed mantles of moderate height (3-4 $\mu \mathrm{m})$ and with small areolae in radial and obliquely intersecting rows, $23-24 / 10 \mu \mathrm{m}$.

\section{COSCINODISCUS GORBUNOVII v. GORBUNOVII SHESHUKOVA In Sheshukova-Poretzkaja \& Moissejeva 1964,}

$$
\text { P. 96, pl. 2, figs. 1-5. }
$$

Description.-Frustules disk-shaped, height 2-3 $\mu \mathrm{m}$, without intercalary bands. Diameter of the valves $35-70 \mu \mathrm{m}$. On the frustule, 13-18 rows of areolae $/ 10 \mu \mathrm{m}$, central zone present, marginal zone narrow, delicately crosshatched. Mantle not developed.

\section{COSCINODISCUS GORBUNOVII v. ETHMODISCOIDUS MOISSEJEVA in Sheshukova-Poretzkaja \& Moissejeva 1964,

$$
\text { P. 96, pl. 3, figs. 1-7. }
$$

Description.-Frustules short-cylindrical with small collar-shaped, structureless intercalary bands, 30-50 $\mu \mathrm{m}$ diameter, and up to $20 \mu \mathrm{m}$ high. 12 areolae rows $/ 10 \mu \mathrm{m}$ on the frustule, central zone absent, marginal zone inconspicuous. Mantle of the frustule 3-4 $\mu \mathrm{m}$ high with small areolae in radial and obliquely intersecting rows, $23-24 / 10 \mu \mathrm{m}$.

Variability and Comments on the Descriptions.-For the most part, the description of Coscinodiscus gorbunovii and varieties is straight forward. Some points however, require discussion and revision.

1. It is not quite clear what is meant by the undulating areolae rows on the valve margin. In direct translation this passage reads, "In the area by the edge are distinct concentric-undulating rows of the same kind of areolae and ***". Published figures of this species (SheshukovaPoretzkaja and Moissejeva, 1964; Cheremisinova, 1968; Moissejeva, 1971; and Temniskova-Topalova and others, 1981) do not clearly illustrate what might be meant by this remark. It is possible that it refers to a wavy pattern of short, interdigitated, and truncated radial areolae rows sometimes visible near the margin of this diatom. Alternatively, it could refer to a looser and somewhat undulate pattern of areolae distributed tangentially along the valve margin and visible in some specimens. The revised description of A. gorbunovii (Khursevich and others, 1990) does not mention this feature. Such patterns are evident on other freshwater Actinocyclus species, however, and are of unknown taxonomic significance.

2. The description of valve disk undulation sounds equivalent to the "shallowly concave" terminology used in this report. Both light and SEM photographs of Coscinodiscus gorbunovii from the literature show individuals that have raised central areas (truly "concentrically undulate") (for example, Temniskova-Topalova and others, $1981 \mathrm{pl}$. 3, fig. 3) among specimens that are shallowly (or deeply) concave. This probably represents normal variation within the species. It appears that undulation consisting of a raised margin and center (for example, in Khursevich and others, 1990) characterizes larger individuals of this species. 
3. The reference to the yellow-brown color of Coscinodiscus gorbunovii is taken to be taxonomically important by Moissejeva (1971). The color of Coscinodiscus gorbunovii or any other diatom for that matter, partly relates to the density of its structural elements, but also to its magnification, the refractive index of the mounting medium, and related optical properties that have nothing to do with the biological characters required for taxonomic separation (Bradbury, 1984).

4. The comment about the presence or absence of "intercalary bands" probably reflects preservation and also seems irrelevant to the description of Coscinodiscus gorbunovii.

5. The "lack of mantle development" suggested for Coscinodiscus gorbunovii v. gorbunovii presumably means that the mantle of this species is short in comparison to that of Coscinodiscus gorbunovii v. ethmodiscoidus.

6. The presence of short, blunt spines associated with the hyaline rays is difficult to confirm by most illustrations of Coscinodiscus gorbunovii. Typically, no spines of any kind are shown, and the only figure that clearly illustrates spines (Temniskova-Topalova and others, 1981, pl. 3, fig. 3), shows a number of irregular, spine-like protrusions along the disk/mantle junction and without clear relation to the hyaline rays. The description of the spines in this case states that they are between the hyaline rays (TemniskovaTopalova and others, 1981). Such spine-like projections (see also Khursevich and others, 1990) may represent an ecotypical variant of this species.

The description of the synonym, Pontodiscus gorbunovii (Shesh.) Shesh. et Moiss. (Temniskova-Topalova and others, 1981), also indicates the presence of external tubules at the openings of the labiate processes, although these are not illustrated. Furthermore, Moissejeva in an oral communication to G.K. Khursevich (written commun., 1989) stated that the labiate processes of Coscinodiscus gorbunovii were mistaken as short spines in the original description of this species.

7. Khursevich and others (1990) gave 16-18 areolae rows $/ 10 \mathrm{~m}$ and $14-18$ areolae $/ 10 \mathrm{~m}$ (presumably along a radial row) for A. gorbunovii. According to Khursevich and others (1990), the coarser Coscinodiscus gorbunovii v. ethmodiscoidus is no longer considered a variety of $A$. gorbunovii. In this report, we follow the revised description with regard to areolar density of $A$. gorbunovii.

\section{ACTINOCYCLUS KRASSKEI (KRASSKE)}

Bradbury \& Krebs nom. nov.

Plate 8, figures 2-6, 8-11; plate 9, figures 1-3

Syn. Coscinodiscus miocenicus Krasske 1934, p. 23, figs. 5-7.

A nomenclatural problem exists with Coscinodiscus miocenicus Krasske. Unmounted type material of this taxon has not been found, precluding SEM investigations to precisely document micromorphological characters of this species. Nevertheless, pseudonodules can be seen by light microscopy in well-preserved specimens of type material (pl. 8, fig. 3). By this and other criteria (see Simonsen, 1982), Coscinodiscus miocenicus can be confidently transferred to Actinocyclus. Because the name Actinocyclus miocenicus Jousé (Jousé, 1973) has preempted the logical new combination, we propose that Actinocyclus krasskei be used to designate this taxon.

Description (From Krasske, 1934).-Valve circular, rather flat, $11-47 \mu \mathrm{m}$ in diameter. Large areolae in radial rows, at the margin about $13 / 10 \mu \mathrm{m}$, organized in unclear fascicles. Secondary rows in clear spirals. Mantle ornamented with delicate areolae organized in three self-crossing linear systems (quincunx), about 20 striae in $10 \mu \mathrm{m}$. Central area lacking. Small individuals show irregular areolation.

Observations of the type material [Beuern (Vogelsberg) Hessen Kieselgur O. Miocene No. 3004 and 3005, No. 24/25] by LM indicate the presence of a comparatively distinct pseudonodule, located between short to mediumlength, hyaline stripes that mark the position of narrow, long-stemmed labiate processes. In addition, concentrically undulate valve disks are common in the material. Areolae along radial rows are about $12-13 / 10 \mu \mathrm{m}$ in type material, although densities of $15-22 / 10 \mu \mathrm{m}$ had been stated for this species (Moissejeva, 1971; Temniskova-Topalova and others, 1981). No external tubes are visible at the labiate process exit pores.

Variability.-As stated by Krasske (1934), small individuals have irregular areolation. The shape of the valve disk varies from flat to concentrically undulate. In the Western United States, diatoms that otherwise conform to Actinocyclus krasskei have somewhat undulate disks and diameters as large as $70 \mu \mathrm{m}$. The large, undulate forms of $A$. krasskei may actually be synonymous with Coscinodiscus gorbunovii, although they tend to be coarser than most Asian examples of $A$. gorbunovii.

Diagnosis.-Moissejeva (1971) stated that the marginal zone of Coscinodiscus gorbunovii is similar to that of Coscinodiscus miocenicus Krasske, but that $C$. gorbunovii is larger, yellow-brown, and concentrically undulate. Type material of Coscinodiscus miocenicus (light yellow or colorless) includes undulate valves whose diameter (11$47 \mu \mathrm{m}$; Krasske, 1934) overlaps with the lower end of the size range reported for Actinocyclus gorbunovii. The color of these diatoms is not taxonomically relevant, and in most other respects $A$. gorbunovii and $A$. krasskei are quite similar. In the type material and in examples of $A$. krasskei from the Western United States, areolae density does not exceed $13 / 10 \mu \mathrm{m}$ along radial areolae rows.

Remarks.-The specific epithet of Actinocyclus krasskei acknowledges the original author of this taxon (Krasske, 1934).

Krasske (1934) reported large quantities of freshwater Aulacoseira and Fragilaria species in association with 
Coscinodiscus miocenicus. The identification of Stephanodiscus astraea (Krasske, 1934) could not be confirmed by close re-inspection of the type material (Reimer Simonsen, written commun., 1984).

Actinocyclus krasskei has been reported as Coscinodiscus miocenicus from the Harper Basin, Malheur County, Oregon (Abbott and VanLandingham, 1972), and from the Squaw Creek Member of the Ellensburg Formation (Miocene) in Yakima County, Washington (VanLandingham, 1964). At both localities, fresh water Aulacoseira species are dominant. At Vinegar Creek, in the Mascall Formation in Grant County, Oregon (loc. 88), and at Juliaetta, Nez Perce County, Idaho (loc. 32), undulate A. krasskei occur with coarsely structured Aulacoseira sp., possibly related to $A$. islandica or $A$. granulata. Flat forms of Actinocyclus krasskei are present in the Latah Formation (Miocene), Spokane County, Washington (loc. 77), and in unnamed Miocene units at Oviatt Creek, Clearwater County, Idaho (loc. 43), and Arrow Junction, Nez Perce County, Idaho (loc. 72). At these localities, Aulacoseira species related to $A$. distans and $A$. praeislandica dominate along with Ellerbeckia arenaria v. teres, Melosira undulata, and species of Eunotia, Tetracyclus, and Tabellaria.

Some diatoms from Siberia, identified as Pontodiscus (=Coscinodiscus) miocenicus, have SEM illustrations of external tubules placed at the hyaline stripes (for example, Temniskova-Topalova and others, 1981, pl. 4, figs. 2, 3, and 8). Khursevich and others (1990) have renamed such diatoms Actinocyclus tubulosus, but this name probably should not be applied to Krasske's (1934) material nor to forms in the Western United States without tubules. Nevertheless, A. tubulosus is also present in the Squaw Creek Member (loc. 49). When the tubules of this diatom are missing because of breakage or corrosion, it cannot be effectively separated from $A$. krasskei by light microscopy (like that of pl. 8, fig. 7).

\section{ACTINOCYCLUS MOTILIS Bradbury and Krebs}

\section{sp. nov.}

Plate 9, figures 4-6; plate 10, figures. 1-12; plate 11, figure 1

Description.-Valve circular, disk slightly concave to weakly concentrically undulate with broadly raised margin. Diameter 20-90 $\mu \mathrm{m}$. Disk with spaced, round areolae in slightly sinuous radial rows (especially near margin). Areolae rows of variable length, interdigitating with one another near margin of disk. Areolae density of type material $11-13 / 10 \mu \mathrm{m}$. Areolae near disk margin noticeably smaller and more crowded (to $16 / 10 \mu \mathrm{m}$ ) than those closer to valve center $(10 / 10 \mu \mathrm{m})$. Fasciculation not apparent. Valve center small and irregularly hyaline with loosely packed areolae. Hyaline rays at disk/mantle junction short, radial, and distinct. Valve/mantle junction typically abrupt, with a steeply sloping mantle. Mantle finely areolate (about $18 / 10 \mu \mathrm{m}$ ) with vertical-quincunx arrangement. Pseudonodule very small (often not visible in LM), located between labiate processes, usually closer to one. Externally, pseudonodule appears on a slightly elevated platform or mound (pl. 11, fig. 1). Internally, it is represented by a small field of several irregular areolae or pores (pl. 10, figs. 4 and 6). Internal expression of pseudonodule on specimens of Actinocyclus motilis from Ellensburg Formation (Squaw Creek Member) is very difficult to differentiate from normal areolation pattern. Labiate processes have long, narrow, circular stems with narrow, flanged labiae.

Variability.-Some variability can be seen in the character of the disk/mantle junction. Typically it is abrupt, but in some specimens it tends to become more gradual and gently sloping. A stellate pattern, caused by the termination of areolae rows, is distinctive in large specimens of this species but absent in smaller ones. As with most species of Actinocyclus, the hyaline central area is quite variable and sometimes absent. Specimens from some localities have hyaline rays that are very small and obscure. Large specimens of Actinocyclus motilis appear to grade into A. cedrus at Goose Creek, Baker County, Oregon (loc. 27), and at the Ellensburg Formation localities in Washington (locs. 49, 59). These forms have coarser, crowded, and somewhat polygonal areolation, especially near the valve center.

Diagnosis.-Actinocyclus motilis is best distinguished by its sinuous, interdigitating rows of round, spaced areolae. This pattern is also visible in $A$. cedrus and $A$. venenosus, but the areolae in these species tend to be larger, uniformly crowded and polygonal. Labiate process labiae are also narrower in A. motilis. Nevertheless, large forms of A. motilis can be confused with the former taxa. The coarseness of areolation separates $A$. motilis from large forms of $A$. gorbunovii and $A$. krasskei.

Types.-Holotype: Strew slide USNM \#465539, E.F. Q39/2.

Isotopes: Strew slides ANSP A.-G.C. \#64469; USGS-D \#23 I 81-10; CAS \#216055.

Type locality.-Actinocyclus motilis is abundant and well preserved in deposits of the Esmeralda Formation at the southeast end of Cedar Mountain, Mineral County, Nevada (loc. 22). This deposit (USGS Denver 23 I 81-10) is chosen as the type locality.

Remarks.-The specific epithet "motilis" (L. motion) refers to an apparent rotational movement of the valve when focusing through it in the light microscope, apparently caused by the sinuous nature of the marginal areolae rows. This species, called Cestodiscus mobilis Lohman (nomen nudum), was first recognized by Lohman (1957) from the Esmeralda Formation near Cedar Mountain, Nye County, Nevada, but here the species is rare, poorly preserved, and mixed with other forms of Actinocyclus. Similar but somewhat coarser forms are extensively figured in VanLandingham (1964) under the name Coscinodiscus subtilis from the 
Squaw Creek Member of the Ellensburg Formation in Yakima County, Washington.

At the type locality, Actinocyclus motilis dominates the assemblage. Associated taxa include freshwater species of Aulacoseira, Tetracyclus, Fragilaria, and occasional fragments of Actinocyclus cedrus.

\section{ACTINOCYCLUS NEBULOSUS}

\section{Bradbury \& Krebs sp. nov.}

\section{Plate 11, figures 2-8; plate 12, figure 1}

Description.-Valve circular, diameter 35-100 $\mu \mathrm{m}$. Disk shallowly concave to slightly concentrically undulate and ornamented with fascicles of areolae. Areolae rows parallel to middle row of each fascicle. Fascicles separated by hyaline, costa-like rays enclosing a single row of widespaced areolae that run from disk margin to center. Areolae in fascicles irregularly spaced on distal third of valve and forming irregularly undulating rows tangential to valve circumference. Areolae small and widely separated (9-12/10 $\mu \mathrm{m})$, and apparently with large and irregularly shaped internal loculae, especially on distal third of disk. Central area of disk variable. Marginal hyaline stripes comparatively long (about $10 \mu \mathrm{m}$ ) and with irregular edges. Stripes merge proximally into hyaline rays and corresponding radial rows of areolae marking fascicle. Disk/mantle junction sharp and mantle steep, finely areolate $(16-20 / 10 \mu \mathrm{m})$ with vertical, slightly quincunx pattern. Labiate processes with broad, recurved flanges and comparatively narrow, circular stems. Pseudonodule small, generally close to labiate process.

Variability.-On some valves, the labiate process stems appear to be shorter and broader than the typical condition. The areolae, especially what are presumed to be their locules, are highly irregular in shape and apparently expanded internally so that the integrity of the areola disappears when focusing through the comparatively thin disk wall. This may be a partial artifact of preservation. The hyaline central area of the valve is highly variable, sometimes discrete and large, other times irregular or absent. Hyaline stripes, because of the irregularity of surrounding areolae, are also variable in shape, length, and clarity.

Diagnosis.-Actinocyclus nebulosus is close to A. ehrenbergii in character of fasciculation, but it can be separated from that species by its small, obscure pseudonodule and the irregular, disorganized arrangement of areolae around the disk margin. A. cupreus is also similar but does not have disorganized areolae on the disk margin, and areolae rows within fascicles are not clearly parallel to the central areolae row. K41.

Types.-Holotype: Strew slide USNM \#465540, E.F.

Isotypes: Strew slides ANSP A.-G.C. \#64479; USGS-D \#26 XII 86-2A; CAS \#216056.
Type Locality.-We designate outcrops of the Esmeralda Formation near Black Spring, Nye County, Nevada (loc. 93 = USGS Denver 26 XII 86-2A), as the type locality of this species.

Remarks.-The specific epithet "nebulosus" (L. cloudy or obscure) refers to the poorly defined marginal region of the valve apparently caused by irregular loculae beneath areoles.

Smedman (1969) described and illustrated this species as Coscinodiscus nevadensis (nomen nudum) from an unnamed formation in Buffalo Canyon, southeast of Eastgate, Churchill County, Nevada (loc. 6), but she failed to designate a type specimen, slide, or a repository. The species is also common near the base of the Cedar Mountain section in Nye County, Nevada (loc. 74), and was described and figured (Lohman, 1957) as Cestodiscus fasciculatus Lohman (nomen nudum).

Aulacoseira sp. cf. A. distans dominates in a sample containing abundant Actinocyclus nebulosus from near Buffalo Canyon, Nevada. Smedman (1969) listed several species of Melosira (Aulacoseira), Cymbella, Pinnularia, Navicula, and Gomphonema in the type assemblage. A. nebulosus is also present in the Mascall Formation near Aldrich Mountain, Grant County, Oregon (loc. 85), where it associates with freshwater Aulacoseira species related to $A$. distans, A. agassizii, and A. islandica. At the type locality, Actinocyclus nebulosus codominates with Aulacoseira spp.

\section{ACTINOCYCLUS PINNULUS Bradbury \& Krebs sp. nov.}

Plate 12, figures 6,7 ; plate 13 , figures $1-5$

Description.- Valve circular, with raised rim and shallowly concave center. Diameter ranging between 47 and 76 $\mu \mathrm{m}$, typically between 65 and $70 \mu \mathrm{m}$. Disk with small, round areolae, about $13 / 10 \mu \mathrm{m}$. Near center of disk, areolae smaller and somewhat loosely packed. On disk margin, areolae larger, closely packed and slightly polygonal in shape. Areolae pattern obscurely fasciculate with two wedge-shaped fascicles of subparallel areolae rows between each pair of labiate processes. Intersection of adjacent sets of subparallel areolae rows evident near the disk margin and less so towards valve center. Valve center generally, but not necessarily, with loosely packed areolae forming irregular hyaline space. Disk/mantle juncture sharp, with mantle perpendicular to disk plane. Mantle 8-10 $\mu \mathrm{m}$ high with tiny areolae in a quincunx pattern, about $18 / 10 \mu \mathrm{m}$. Marginal, hyaline stripes narrow, about $5 \mu \mathrm{m}$ long and extending from disk-mantle juncture onto valve disk. External tubules of labiate processes with a narrow stem, ornamented with two or more fin-like projections resembling pinnae or small leaflets attached parallel to tubule axis. Labiate processes long stemmed, with comparatively small, recurved and flexed 
labiae. Pseudonodule small to medium, often obscurely visible between two labiate processes.

Variability.-Actinocyclus pinnulus is known only from three localities in the Western United States (locs. 81, 90, 91). Different collections of $A$. pinnulus from the Holein-the-Wall diatomite quarry (Miocene), Gooding County, Idaho (locs. 90, 91), show variations in the degree of central area development; in some populations the central areas are mostly absent or very small, while in others they are typically large and irregular. The pseudonodule is larger and more visible in some specimens than others, and the fins on the external tubules of the labiate processes exhibit some variation apart from differences in preservation. Generally, each tubule has two opposite fins that lie in a plane tangential to the valve circumference. Rarely, individual tubules will have three or even four fins irregularly placed along the tubule axis. Fasciculation and diameter of $A$. pinnulus appear comparatively uniform.

At $986 \mathrm{~m}$ depth in the AMOCO Becharof No. 1 well, Alaska (loc. 112), a nonmarine species of Actinocyclus related to $A$. pinnulus is rare (pl. 13, fig. 6). It resembles $A$. pinnulus by the presence of flanged marginal apiculae and general pattern of fasciculation, although the areolae are smaller and less polygonal than in the species. It also differs from the species in having a sloping mantle with vertical (not a quincunx pattern) areolae rows.

Diagnosis.-Actinocyclus pinnulus is closest to $A$. acanthus. A. acanthus does not, however, have tubules with fins, is non-fasciculate, and has only tiny, obscure hyaline stripes in contrast to $A$. pinnulus. A. nordlingensis has forked, not finned tubules, and Coscinodiscus (= Actinocyclus) gorbunovii apparently lacks tubules.

Types.-Holotype: Strew slide USNM \#465541, E.F. L34/2.

Isotypes: Strew slides ANSP A-G.C. \#64471; USGS-D \#21 VI 88-1; CAS \#216057.

Type Locality.-The type locality for Actinocyclus pinnulus is the Hole-in-the-Wall diatomite quarry, NW $1 / 4 \mathrm{sec}$. 12, T. 4 S., R. 13 E., Gooding County, Idaho (loc. 90), along the drainage of Clover Creek.

Remarks.-The specific epithet "pinnulus" (L. small fin or pinna) refers to the fin-like projections on the external tubes of the labiate processes of this diatom.

The species has also been collected from the same unit exposed in the NE $1 / 4$ of sec. 19, T. 3 S., R. 13 E. (loc. $91=$ USGS Denver 21 VI 88-1). Aulacoseira sp. cf. A. praeislandica is the dominant associate of Actinocyclus pinnulus, and a species of Mesodictyon Theriot and Bradbury (Thalassiosiraceae) is present in smaller numbers. Mesodictyon also occurs with $A$. pinnulus in the unnamed lacustrine beds at Durkee, Baker County, Oregon (loc. 81).

\section{ACTINOCYCLUS THELEUS Bradbury \& Krebs sp. nov.}

Plate 13, figure 7; plate 14 , figures $1-4$

Description.-Valve circular, concentrically undulate with broadly raised margin and shallowly raised or depressed center. Diameter 11-35 $\mu \mathrm{m}$, typically around $20 \mu \mathrm{m}$. Areolae small, round, loosely packed, about 13$18 / 10 \mu \mathrm{m}$ and not forming clear fascicles. Areolae in valve center often scattered, but not always. Hyaline stripes inconspicuous, narrow, and extending onto disk edge. Exit pores of labiate processes with a low, shield-shaped or nipple-like protrusion rising about $1 \mu \mathrm{m}$ above valve surface. Valve mantle perpendicular, with vertical rows of fine areolae, about $25 / 10 \mu \mathrm{m}$. Labiate processes with narrow, round stems and spade-shaped labiae with curved, slit-like openings. Pseudonodule generally small but prominent and variably located between labiate processes at valve-disk margin.

Variability.-The nipple-like protrusions at the exit pores of the labiate processes and associated hyaline stripes may be more or less prominent, perhaps as a result of preservation. At Emerald Creek, Benewah County, Idaho (loc. 21), degree of undulation and density of areolae vary considerably. Generally poor preservation of the species at Oviatt Creek, Clearwater County, Idaho (loc. 43), complicates comparison of these forms, but in general they appear flatter than the Emerald Creek forms, and with reduced shield-like processes. At Juliaetta, Nez Perce County, Idaho (loc. 32), and at the White Hills (Mascall Formation), Grant County, Oregon (loc. 87), A. thelelus tends to be coarser and more heavily silicified than at Emerald Creek. Perhaps the larger and coarser members of this complex merit separation.

Diagnosis.-Actinocyclus theleus is characterized by the presence of nipple-like tubules external to the labiate processes and by its typically undulate shape and fine areolation. It can be distinguished from small forms of $A$. gorbunovii and $A$. krasskei by the presence of the shield-like platforms that subtend the small external processes. The external processes of Actinocyclus acanthus are heavier, larger, and longer than those of $A$. theleus.

Types.-Holotype: Strew slide USNM \#465542, E.F. M34/4.

Isotypes: Strew slides ANSP A-G.C. \#64472; USGS-D \#5 XII 80-4; CAS \#216058.

Type Locality.-Finely laminated lacustrine siltstone from the "Clarkia Lake deposits" of Miocene age from Emerald Creek, near Clarkia, Idaho (loc. 21 = USGS Denver 5 XII 80-4) represents the type locality of Actinocyclus theleus. The sample location is in the NW $1 / 4, N E 1 / 4$, sec. 33, T. 43 N., R. 1 E., Benewah County, Idaho (= locality UIMM P-37, Smiley and Rember, 1985, at Emerald Creek; loc. 21). 
Remarks.-The specific epithet "theleus" (G. nipple) refers to the character of the external tubes of the labiate processes.

The species is figured as Actinocyclus sp. in Bradbury and others (1985), and at both Emerald Creek and at Oviatt Creek, Clearwater County, Idaho (loc. 43), it co-occurs with abundant Aulacoseira species related to A. lirata and $A$. distans, and a large variety of benthic diatoms indicative of soft, fresh, humic-rich, slightly acid water. Actinocyclus theleus is not widely distributed, and it may be that this form is characteristic of softwater, slightly acid environments. The coarser and larger forms at Juliaetta (loc. 32) and the White Hills (Mascall Formation), Grant County, Oregon (loc. 87) are associated with heavily silicified Aulacoseira sp. (cf. A. praeislandica) that may indicate more silicon-rich, eutrophic environments.

\section{ACTINOCYCLUS TUBULOSUS Khursevich}

(Khursevich and others, 1990)

Plate 8, figure 7

Remarks.-This small, fine Actinocyclus species with short external tubules of circular cross section occurs rarely in the Squaw Creek Member of the Ellensburg Formation in central Washington. Poorly preserved specimens (lacking external tubules) may be misidentified as Actinocyclus krasskei that is otherwise similar (for example, TemniskovaTopalova and others, 1981). The specimen figured (pl. 8, fig. 7), has external tubules that appear above the focal plane in light microscopy. The type locality is in western Siberia along the Tim River (Khursevich and others, 1990).

\section{ACTINOCYCLUS VENENOSUS}

Bradbury \& Krebs sp. nov.

Plate 14, figures 7, 8; plate 15 , figures $1-6$

Description.-Valve circular, with broadly raised rim and shallowly concave to concentrically undulate valve disk. Diameter 35 to $>160 \mu \mathrm{m}$, but typically around 70 to $100 \mu \mathrm{m}$ in type material. Disk with coarse (about $1 \mu \mathrm{m}$ diameter) polygonal areolae arranged in approximately radial rows, 610 in $10 \mu \mathrm{m}$. Areolae pattern non-fasciculate or vaguely fasciculate. In medium to large specimens, shorter areolae rows interspersed between longer rows terminate in narrow triangles of hyaline silica at variable distances from valve margin. Valve center either tightly or loosely packed with areolae. Disk/mantle juncture often loosely and irregularly areolate and typically unornamented. Occasionally, closely spaced, keel-like spines present along the disk/mantle junction. Marginal hyaline stripes prominent (often $2-3 \mu \mathrm{m}$ in length) and proximally pointed or tapered. Stripes usually extend across valve mantle and onto valve disk. On mantle, marginal hyaline stripes enclose comparatively large and often elliptical exit pores of labiate processes. Labiate processes typically short, broad-stemmed, and with broad, recurved, crescentic, spade-like labium. Pseudonodule small, at disk/mantle junction, and typically closer to one labiate process.

Variability.-Like other species of Actinocyclus, A. venenosus varies morphologically. The hyaline stripes are usually rather long and prominent but may be comparatively small; some variation is seen on single valves. They are generally easily seen at low magnifications. Typically, the disk/mantle junction is broad, and the mantle gently slopes away from the plane of the disk. In some specimens, however, the junction is sharper and the mantle more steeply sloping. Labiate processes usually have short, elliptical stems and broad, recurved, crescent-shaped labiae, but occasionally, relatively taller, more circular-stemmed labiate processes occur. Fasciculation is occasionally evident. It is not certain whether these variations, which tend to co-occur (fasciculation, steep, sharp mantles, and sometimes longer labiate processes), represent intraspecific variation or characters of Actinocyclus cedrus. More fasciculate forms of this species occur in the Coal Valley Formation (Miocene), Lyon County, Nevada (loc. 15).

Diagnosis.-Actinocyclus venenosus is best recognized by its prominent hyaline stripes, broad disk/mantle junction, gradually sloping mantle, radial, non-fasciculate areolation, and concentric undulation of the valve disk. It is closest to $A$. cedrus, and type material can usually be separated from this species that typically has a sharp disk/mantle junction, a steep, tall mantle, more evident and consistent fasciculation, and minute, blunt hyaline stripes. Nevertheless, intergradations occur at other sites that frustrate simple separation, and broken valves may be impossible to identify.

Actinocyclus cupreus is distinguished from A. venenosus by the presence in the former of continuous radial areolae rows that extend from each labiate process to the valve center. Actinocyclus cupreus is also somewhat more finely structured (13 rounded-polygonal areolae $/ 10 \mu \mathrm{m}$ ) and has labiate processes with comparatively long stems.

Types.-Holotype: Strew slide USNM \#465543, E.F. E39.

Isotypes: Strew slides ANSP A-G.C. \#64473; USGS-D \#11 VI 78-1A; CAS \#216059.

Type Locality.-The type locality is at Reynolds Creek, Owyhee County, Idaho (NW l/4 sec. 2, T. 2 S., R. 3 W.) (loc. 44 = USGS Denver 11 VI 78-1A).

Remarks.-The specific epithet "venenosus" (L. very poisonous) refers to its abundance in the Poison Creek Formation of the Idaho Group, western Snake River Plain, Idaho.

This species, labeled Actinocyclus sp. cf. A. gorbunovii from the Poison Creek Formation and from diatomaceous deposits in the Xian Feng Basin near Kunming, China is figured in Bradbury (1984). Actinocyclus sp. (Khursevich and others, 1990) from the Primor region of western Siberia appears to be closely related to A. venenosus. Associated 
diatoms at the type locality are dominated by Aulacoseira species. Navicula, Diploneis, Tetracyclus, Cymbella, Stauroneis, and several other genera are present in smaller numbers.

\section{PALEOECOLOGY OF MIOCENE LACUSTRINE ACTINOCYCLUS}

Between 20 and $10 \mathrm{Ma}$, species of Actinocyclus were the dominant planktonic discoid diatoms of temperate lake systems in the Northern Hemisphere. With the clear exception of Actinocyclus ehrenbergii, and possibly of A. acanthus, the Actinocyclus species from Miocene lacustrine deposits in the Western United States are freshwater planktonic diatoms. Actinocyclus krasskei and A. theleus seem to have dominated in smaller, neutral to slightly acidic lake systems (for example, Bradbury and others, 1985), while the larger and more coarsely structured forms, A. motilis, A. cedrus, and $A$. venenosus, appear to have been characteristic of larger, more eutrophic, slightly alkaline environments.

Little is known about the limnology of the lakes inhabited by Actinocyclus. It is reasonable to assume that large Miocene lakes in the Western United States were warm monomictic; that is, circulating in the winter at temperatures above $4^{\circ} \mathrm{C}$ because Miocene climates were less seasonal and winters milder. By analogy to modern lake systems, Aulacoseira species would dominate the diatom plankton during times of circulation where turbulence could suspend the heavy cells and supply nutrients to the photic zone. Actinocyclus normanii f. subsalsa is the only known extant Actinocyclus species living in freshwater. Its ecology is not well known, although in Lake Ontario it prefers nutrient-enriched water and reaches maximum populations in late summer (Stoermer and others, 1974). In contrast, Aulacoseira islandica blooms in late spring and early summer in Lake Ontario (Stoermer and others, 1974), during or shortly following spring circulation in less contaminated parts of the lake.

The common association of Actinocyclus and Aulacoseira species in Miocene lakes suggests that perhaps the two diatoms occupied limnological niches similar to their counterparts in Laurentian Great Lakes. Nonetheless, extrapolation from the modern distribution of Actinocyclus normanii f. subsalsa may be compromised by the fact that this species has significant morphological differences compared to Miocene Actinocyclus species (for example, lack of hyaline stripes and apparently a structurally more complicated pseudonodule).

\section{REFERENCES}

Abbott, Jr., W.H., and VanLandingham. S.L., 1972, Micropaleontology and paleoecology of Miocene non-marine diatoms from the Harper District, Malheur County, Oregon: Nova Hedwigia, v. 13, p. $847-906$.
Blake, W.P., 1902, Arizona diatomites: Transactions of the Wisconsin Academy of Sciences, Arts, and Letters, v. XIV, pt. 1, p. 107-111.

Bradbury, J.P., 1984, Fossil Actinocyclus species from freshwater Miocene deposits in China and the United States, in Mann, D. G. (ed.), Proceedings of the 7th International Diatom Symposium, Philadelphia, 22-27 August, 1982: Koenigstein, Germany, KoeItz, p. 157-171.

Bradbury, J.P., Dieterich, K.V., and Williams, J.L., 1985, Diatom flora of the Miocene lake beds near Clarkia in northern Idaho, in Smiley, C. J. (ed.), Late Cenozoic history of the Pacific Northwest: San Francisco, California, Pacific Division of the American Association for the Advancement of Science, p. 33-59.

Bradbury, J.P., and Krebs, W.N., 1982, Neogene and Quaternary lacustrine diatoms of the western Snake River Basin, Idaho-Oregon, USA: Acta Geologica Academiae Scientiarum Hungaricae, v. 25, no. 1-2, p. 97-122.

Burckle, L.H., and Akiba, Fumio, 1978, Implications of late Neogene fresh-water sediment in the Sea of Japan: Geology, v. 6, p. $123-127$.

Cheremisinova, E.A., 1968, New data about the diatoms of the Neogene deposits of the Baikal area, in Fossil Diatoms of the USSR: Moscow, USSR, Academy of Science, Siberian Division, Institute of Geology and Geophysics, p. 71-74.

Frenguelli, Joaquin, 1928, Diatomeas del Océano Atlántico frente a Mar deI Plata (República Argentina): Anales deI Museo NacionaI de Historia Natural, Tomo XXXIV, p. 497-572.

Hajós, Marta, 1970, Kieselgurvorkommen im Tertiärbecken von Aflenz (Steiermark): Mitteilungen der Geologischen Gesellschaft in Wien. v. 63, p. 149-159.

Hasle, G.R., 1977, Morphology and taxonomy of Actinocyclus normanii f. subsalsa (Bacillariophyceae): Phycologia, v. 16, no. 3, p. 321-328.

Hustedt, Friedrich, 1930, Die Kieselalgen Deutschlands, Österreichs und der Schweiz unter Berücksichtigung der übrigen Länder Europas sowie der angrenzenden Meeresgebiete, in Rabenhorst, L., Kryptogamen-Flora von Deutschland, Österreich und der Schweiz: Leipzig, Akademische Verlagsgesellschaft m.b.H., Band VII, 920 p.

Jousé, A.P., 1973, Diatoms in the Oligocene-Miocene biostratigraphic zones of the tropical areas of the Pacific Ocean, in Simonsen, Reimer (ed.), Second symposium on recent and fossil marine diatoms: Beihefte zur Nova Hedwigia, Heft 45, p. 333-363.

Khursevich, G.K., Moisseeva, A.I., Kozirenko, T.F., and Rubina, N.V., 1990, New taxa of the genus Actinocyclus (Bacillariophyta) from the Neogene freshwater deposits of the USSR: Botanicheski Zhurnal v. 75, no. 10, p. 1439-1442.

Koizumi, Itaru, 1988, Early Miocene Proto-Japan sea: Journal of the Palcontological Society of Korea. v. 4, p. 6-20.

Krasske, Georg, 1934, Die Diatomeenflora der hessischen Kieselgurlager: Sitzungsberichte der Heidelberger Akademie der Wissenschaften, Abhandlung 5, $26 \mathrm{p}$.

Krebs, W.N., Bradbury, J.P., and Theriot, E.C., I987, Neogene and Quaternary lacustrine diatom biochronology, western USA: Palaios, v. 2, p. 505-513.

Lohman, K.E., 1957, Cenozoic non-marine diatoms from the Great Basin: Pasadena, California Institute of Technology, Ph.D. dissertation, $190 \mathrm{p}$. 
Mann, D.G., 1988, The nature of diatom species: analysis of sympatric populations, in Round, F. E., Proceedings of the 9th International Diatom Symposium: Bristol, Biopress Ltd., p. 317-327.

Moissejeva, A.I., 1971, Atlas of the Neogene diatom algae of the Primor region: Moscow, USSR, AIl Union Lenin Order of Scientific Investigation, Geological Institute, new series, v. $171,152 \mathrm{p}$.

Pritchard, A., 1861, A history of infusoira including the Desmidiaceae and Diatomaceae British and foreign: London, 4th Edition, Whittaker and Co., $968 \mathrm{p}$.

Radionova, E.P., 1987, Diatom morphology of the genus Cestodiscus from lower middle Miocene deposits of the tropical zone of the Pacific Ocean: Academy of Sciences, USSR, Institute of Geology, Micropaleontology Edition, Issue 29, p. 141-154.

Schauderna, Hedwig, 1983, Die Diatomeenflora aus den Miozänen Seeablagerungen im Nördlinger Ries: Paleontographica, Abteilung B, Band 188, p. 83-193.

Sheshukova-Poretzkaja, V.S., and Moissejeva, A.I., 1964, New and curious diatoms from the Neogene of western Siberia and the Far East: New Systematics of Lower Plants. Academy of Science, USSR, Botanical Institute, M-L, p. 92-103.

Simonsen, R., 1975, On the pseudonodulus of the centric diatoms, or Hemidiscaceae reconsidered: Beihefte zur Nova Hedwigia, Heft 53, p. 83-94.

1982, Notes on the diatom genus Charcotia M. Peragallo: Bacillaria, v. 5, p. 101-116.

Smedman, Gunilla, 1969, An investigation of the diatoms from four Tertiary Iake bed deposits in western Nevada: PaleoBios (Contributions from the University of California Museum of Paleontology, Berkeley) no. 9, 16 p.

Smiley, C.J., and Rember, W.C., 1985, Physical setting of the Miocene Clarkia fossil beds, northern Idaho, in Smiley, C.J. (ed.), Late Cenozoic history of the Pacific Northwest: San Francisco, California, Pacific Division of the American Association for the Advancement of Science, p. 11-31.
Sovereign, H.E., 1963. New and rare diatoms from Oregon and Washington: Proceedings of the California Academy of Sciences. 4th Series v. 31, no. 14 p. 349-368.

Stoermer, E.F., Bowman, M.M., Kingston, J.C., and Schadel, A.L., 1974. Phytoplankton composition and abundance in Lake Ontario during IFYGL: Special report no. 53 of the Great Lakes Research Division. University of Michigan, 373 p.

Stoermer, E.F., Wolin, J.A., Schelske, C.L., and Conley, D.J., 1985, Assessment of ecological changes during the recent history of Lake Ontario based on siliceous algal microfossils preserved in Iake sediments: Journal of Phycology, v. 21, p. 257-276.

Temniskova-Topalova, D.N., Kozyrenko, T.F., Moisseeva, A.I., and Sheshukova-Poretzkaya, V.S., 1981. A new genus Pontodiscus (Bacillariophyta): Botaniska Zhurnal (Leningrad), v. 66, p. 1308-13I1.

Theriot, E.C., and Stoermer, E.F., 1984, Principal component analysis of character variation in Stephanodiscus niagarae Eherenb.: Morphological variation related to lake trophic status, in Mann, D.G., (ed.), Proceedings of the 7th International Diatom Symposium, Philadelphia, 1982: Koenigstein, Germany, Koeltz, p. 97-111.

Tsoy, I.B., Vashchenkova, N.G., Gorovaya, M.T., and Terekhov, Ye.P.. 1985, The finding of continental deposits on Yamato Rise, Sea of Japan: Tikhookeanskaya Geologiya (Pacific Geology), no. 3, p. 50-55.

VanLandingham, S.L., 1964, Miocene non-marine diatoms from the Yakima region in south-central Washington: Beihefte zur Nova Hedwigia, Heft 14.78 p.

1967, Paleoecology and microfloristics of Miocene diatomites from the Otis Basin-Juntura region of Harney and Malheur Counties, Oregon: Beihefte zur Nova Hedwigia, Heft $26,77 \mathrm{p}$.

Watkins, T.P., and Fryxell, G.A., 1986, Generic consideration of Actinocyclus: consideration in light of three new species: Diatom Research, v. 1, p. 291-312. 


\section{PLATES 1-15}

Contact photographs of the plates in this report are available, at cost, from the U.S. Geological Survey Photographic Library Federal Center, Denver, Colorado 80225 


\section{PLATE 1}

Figures 1-9. Actinocyclus acanthus Bradbury \& Krebs, sp. nov. (p. 4). Scale bars in $\mu \mathrm{m}$.

1. Unnamed Miocene unit, New Pass, Lander County, Nevada (loc. 42). Arrows mark marginal tubular processes at disk/mantle junction and concentric undulation of valve. Diameter $65 \mu \mathrm{m}$. Slide USGS-D 14 VII 85-4 (2), E.F. G32/1.

2. New Pass, Lander County, Nevada (loc. 42). Internal view showing pseudonodule (arrow). Diameter $55 \mu \mathrm{m}$. Slide USGS-D 14 VII 85-4 (2), E.F. L45/3.

3. Bully Creek Formation, Harper Basin, Malheur County, Oregon (loc. 7). Valve view of exterior surface showing obscure pseudonodule (arrow). Diameter $69 \mu \mathrm{m}$. Slide AMOCO: OM-29-1(+), E.F. K4/4.

4-6. New Pass, Lander County, Nevada (loc. 42). Internal views showing pseudonodule (arrows in figs. 4,5 ) and labiate process (fig. 6).

7, 8. New Pass, Lander County, Nevada (loc. 42). Detail of marginal tubular processes.

9. New Pass, Lander County, Nevada (loc. 42). Base of broken marginal tubular process. 

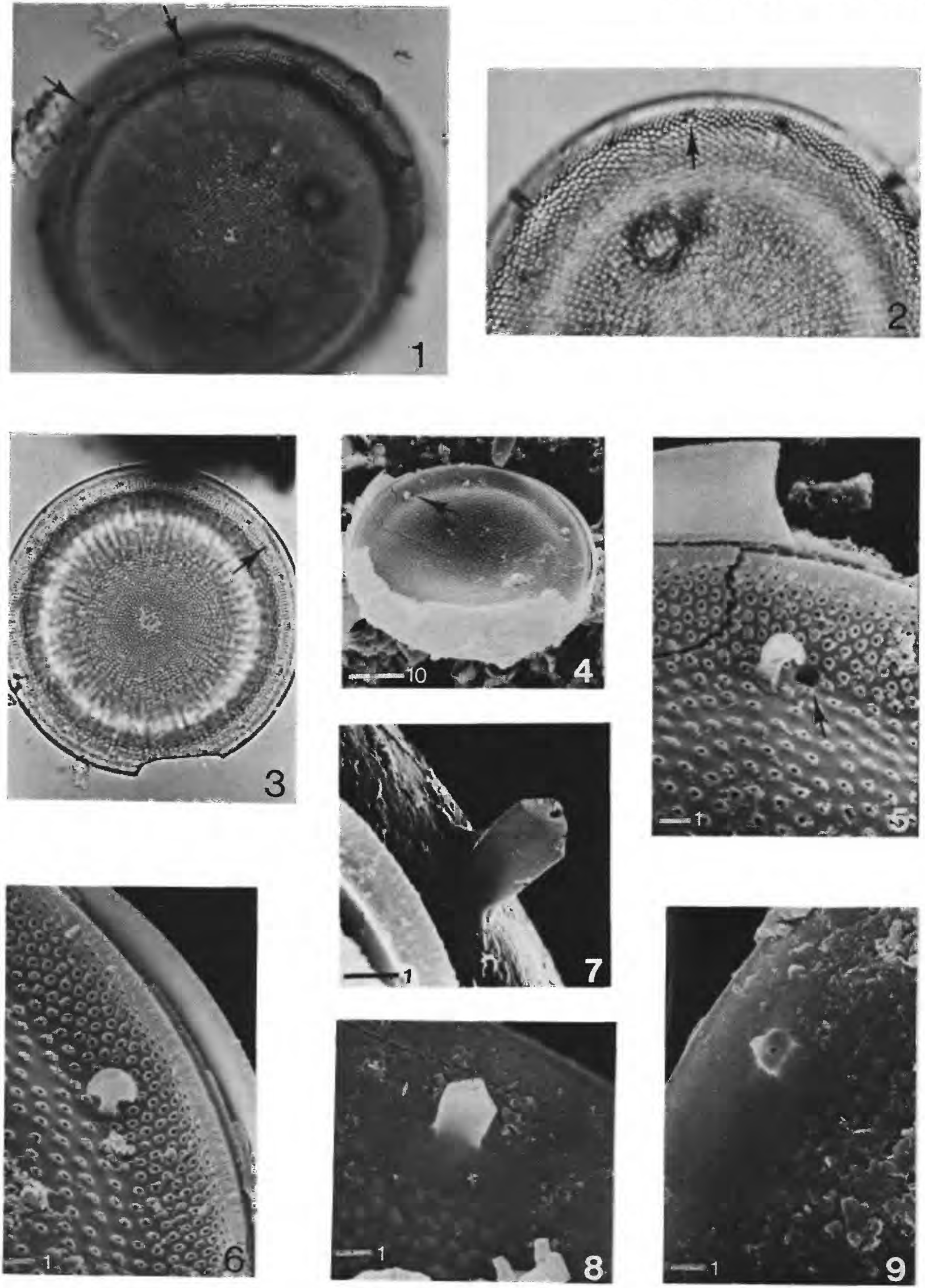


\section{PLATE 2}

Figures 1-7. Actinocyclus cedrus Bradbury \& Krebs, sp. nov. (p. 5).

1. Esmeralda Formation, Diatomite Ridge, Mineral County, Nevada (loc. 20). Note short, blunt hyaline stripe at the disk/mantle junction (arrow) and polygonal areolae. Diameter $53 \mu \mathrm{m}$. Slide USGS-D 31 I 88-1 (65), E.F. P41/1.

2. Esmeralda Formation, Diatomite Ridge, Mineral County, Nevada (loc. 20). Valve with hyaline rim. Diameter $56 \mu \mathrm{m}$. Slide USGS-D 31 I 88-1 (65), E.F. LA1/4.

3. Esmeralda Formation, Diatomite Ridge, Mineral County, Nevada (loc. 20). Arrow marks pseudonodule. Diameter $45 \mu \mathrm{m}$. Slide USGS-D 31 I 88-1 (65), E.F. M32.

4. Poison Creek Formation, Reynolds Creek, Owyhec County, Idaho (loc. 44). Detail of valve surface showing pseudonodule (arrow). Diameter $85 \mu \mathrm{m}$. Slide AMOCO: IO-24-5(+), E.F. O9/2.

5. Unnamed Miocene unit, southern Stillwater Mountains, Churchill County, Nevada (loc. 48). Detail of disk and mantle under different focus (a, mantle; b, disk center). Diameter is $67 \mu \mathrm{m}$. Slide USGS-D 29 I 81-3B, E.F. N38

6. Juntura (?) Formation, Otis Creek, Harney County, Oregon (loc. 34). Diameter $68 \mu \mathrm{m}$. Slide USGS-D 14 VI 78-4B (3), E.F. O34/4.

7. Juntura (?) Formation, Otis Creek, Harney County. Oregon (loc. 34). Large valve with triangular hyaline patches between rows of areolae producing stellate pattern. Diameter $157 \mu \mathrm{m}$. Slide USGS-D 14 VI 78-4B (3), E.F. O32/1. 
U.S. GEOLOGICAL SURVEY
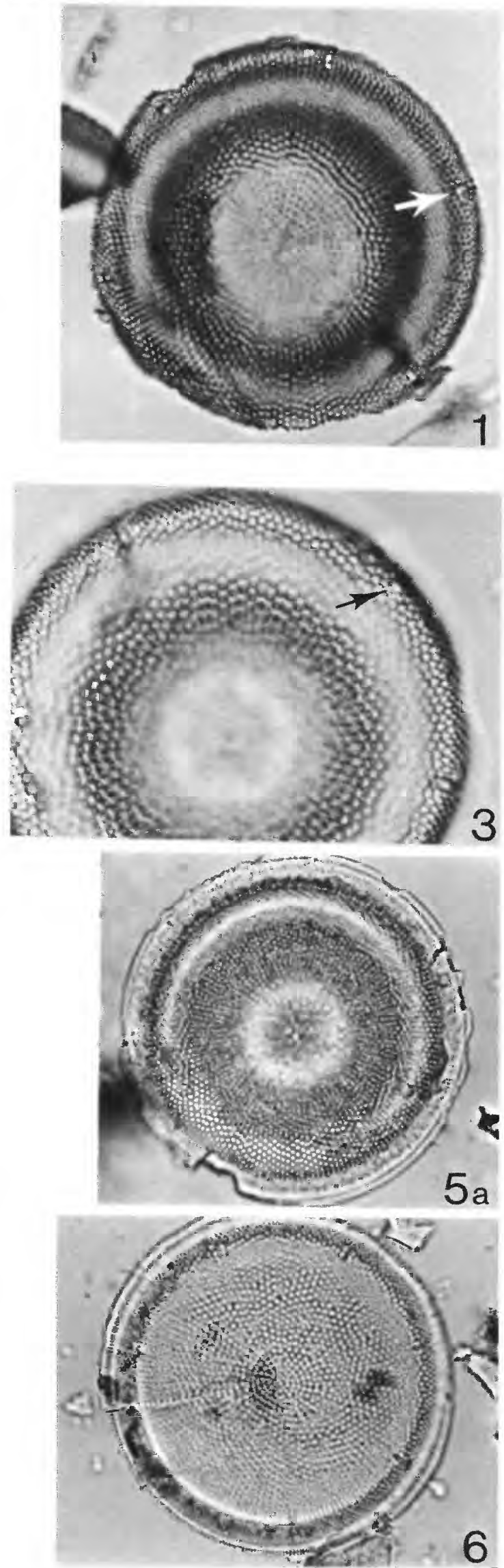

PROFESSIONAL PAPER 1543 PLATE 2
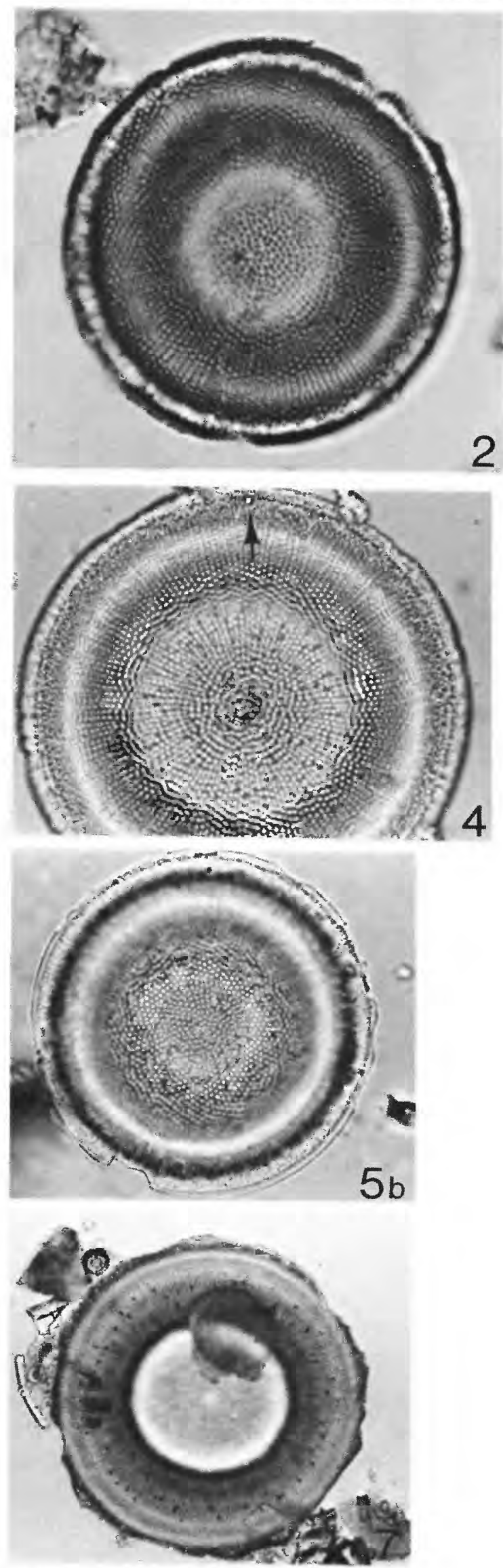


\section{PLATE 3}

Figures 1-8. Actinocyclus cedrus Bradbury \& Krebs, sp. nov. (p. 5). Scale bars in $\mu \mathrm{m}$.

1. Unnamed Miocene unit, southern Stillwater Mountains, Churchill County, Nevada (loc. 48). Valve with hyaline rim. Diameter $49 \mu \mathrm{m}$. Slide AMOCO: S.E. Carson Sink-low (-), E.F. Q4/3.

2, 3. Esmeralda Formation, Diatomite Ridge, Mineral County, Nevada (loc. 20). Valve exterior with hyaline rim and exit pores of labiate processes (arrows).

4, 5. Esmeralda Formation, Diatomite Ridge, Mineral County, Nevada (loc. 20). Exit pores of labiate processes indicated by arrows.

6. Esmeralda Formation, Diatomite Ridge, Mineral County, Nevada (loc. 20). Detail of valve margin and mantle. The arrow pinpoints an exit pore.

7, 8. Esmeralda Formation, Diatomite Ridge, Mineral County, Nevada (loc. 20). Overview of valve interior (fig. 7) and detail of disk/mantle junction showing labiate process and position of pseudonodule (arrow) (fig. 8). 
U.S. GEOLOGICAL SURVEY
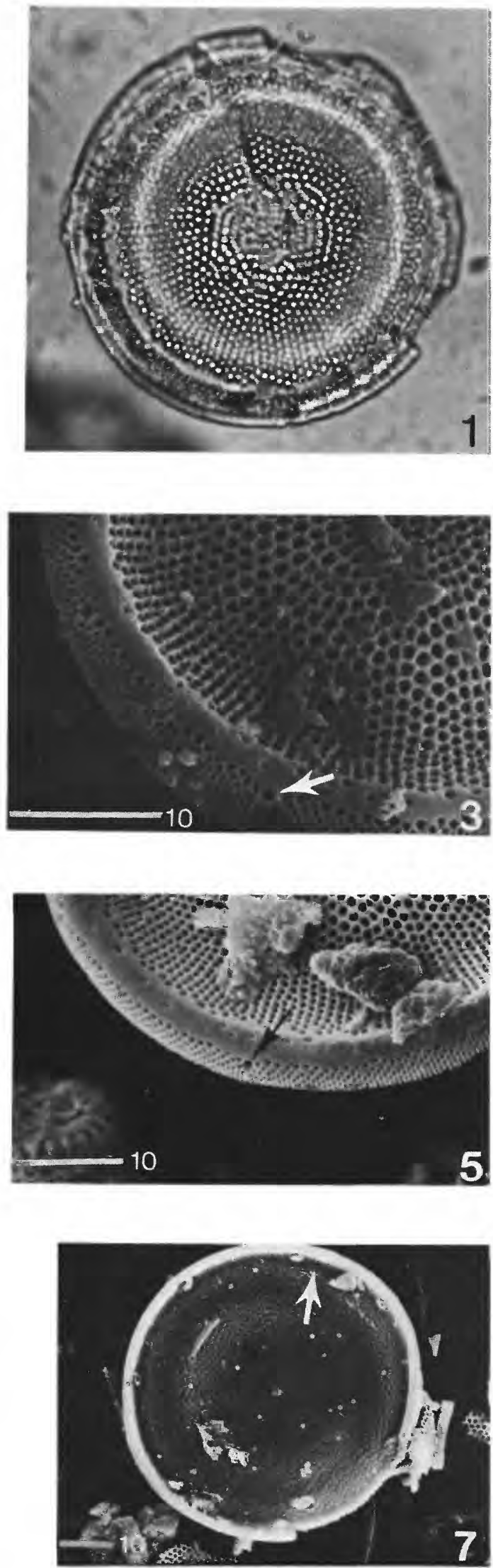
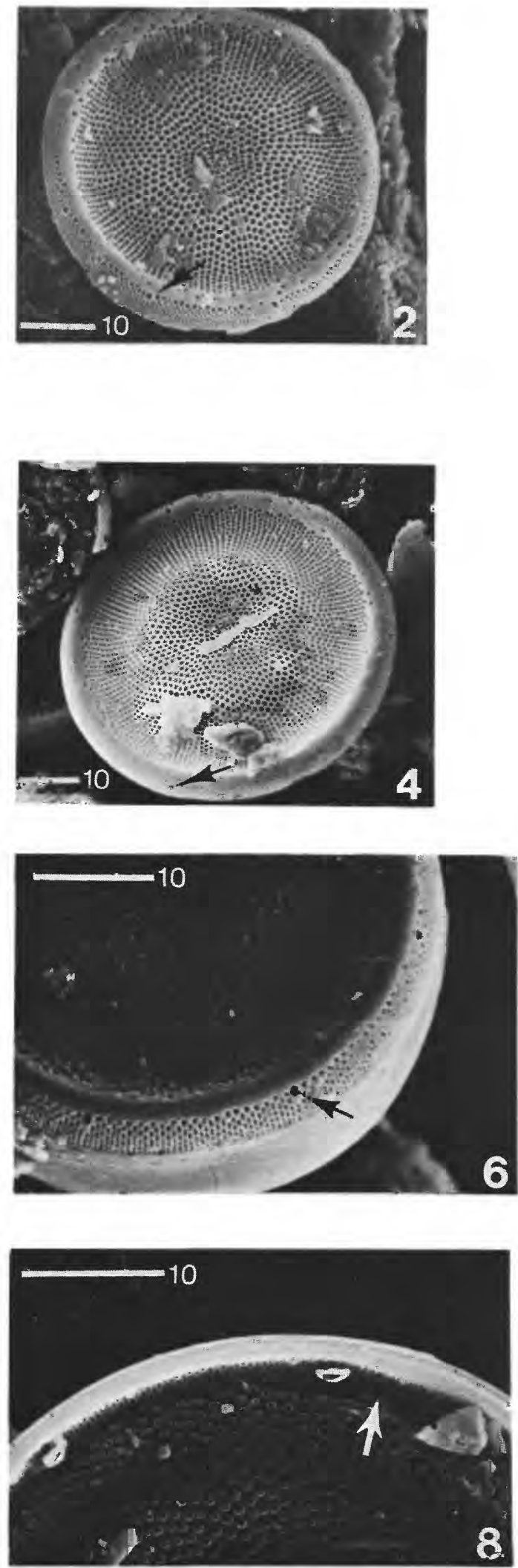


\section{PLATE 4}

Figures 1-3. Actinocyclus cedrus Bradbury \& Krebs, sp. nov. (p. 5). Esmeralda Formation, Diatomite Ridge, Mineral County, Nevada (loc. 20). Scale bars in $\mu \mathrm{m}$.

1. Overview of valve interior showing ring of labiate processes. Arrow marks location of pseudonodule.

2. Closeup of labiate processes.

3. Internal view of pseudonodule (arrow).

4-6. Actinocyclus cedrus (spinose form) (p. 5). Unnamed Miocene unit, Turner Crcek, Modoc County, California (loc. 17). Scale bars in $\mu \mathrm{m}$.

4. Valve view; arrows highlight marginal spines. Diameter is $91 \mu \mathrm{m}$. Slide AMOCO: Pit River (+30), E.F. T72.

5,6. Views of marginal spines.

7. Actinocyclus claviolus Bradbury \& Krebs, sp. nov. (p. 5). Unnamed middle Miocene unit, Jungle Point, Idaho County, Idaho (loc. 33). Note clove-shaped hyaline stripes on disk/mantle junction. Diameter $21 \mu \mathrm{m}$. Slide USGS-D 5 XII 80-7 (1), E.F. S37/1. 

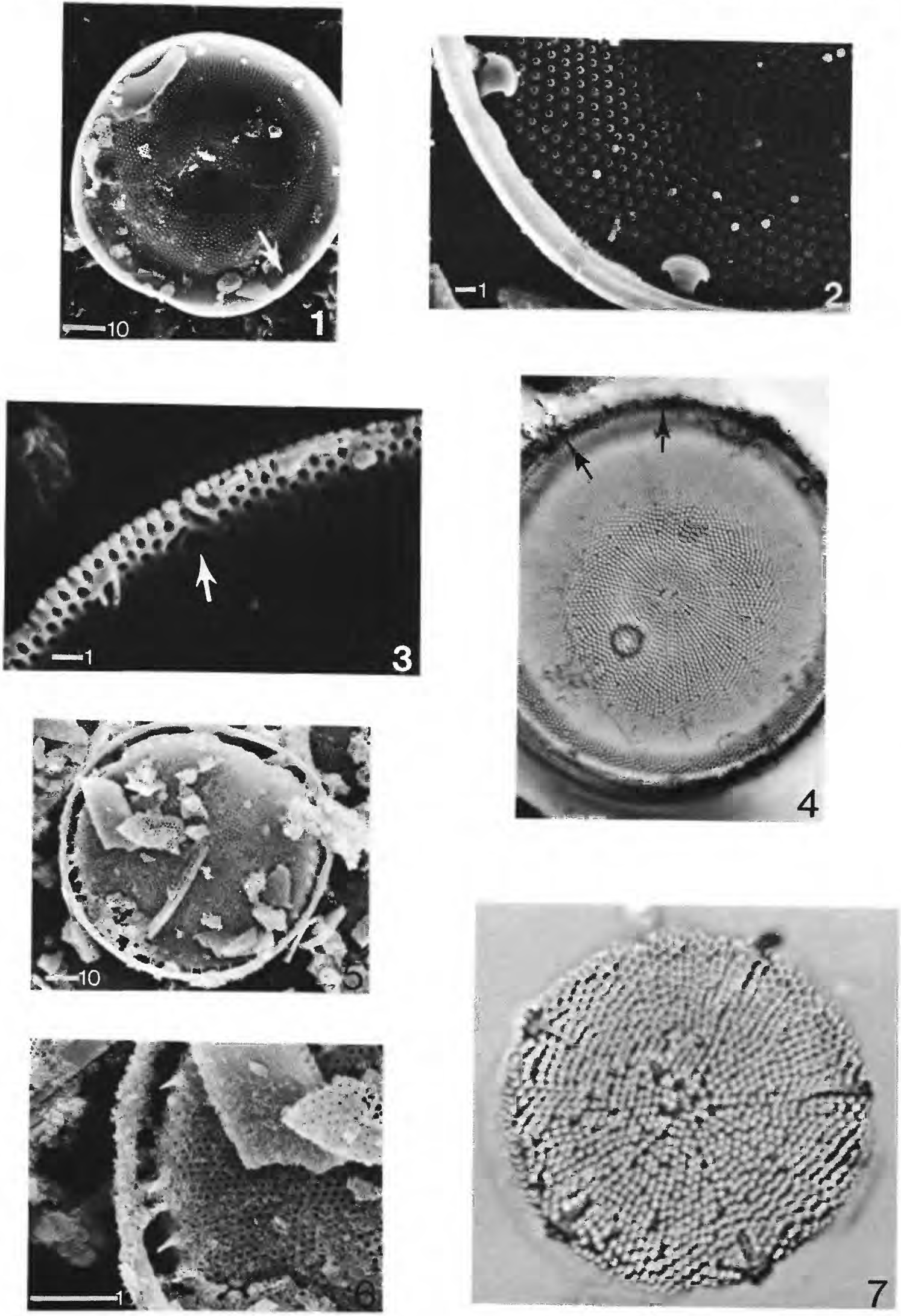


\section{PLATE 5}

Figures 1-5. Actinocyclus claviolus Bradbury \& Krebs, sp nov. (p. 5). Unnamed middle Miocene unit, Jungle Point, Idaho County, Idaho (loc. 33). Scale bars in $\mu \mathrm{m}$.

1. Valve view. Diameter $30 \mu \mathrm{m}$. Slide USGS-D 5 XII 80-7 (3), E.F. J33/2.

2. Valve view. Arrow marks probable pseudonodulc.

3. Detail of marginal clove-shaped hyaline stripe.

4. Valve interior showing position of pseudonodulc (arrow).

5. Internal view of pseudonodule (arrow).

6-9. Actinocyclus cupreus Bradbury \& Krebs, sp. nov. (p. 6).

6. Unnamed lower Miocene unit. Copper Kettle Canyon, Churchill County, Nevada (loc. 16). Note the pattern of fasciculation and the simple hyaline marginal stripes that delimit each fascicie. Diameter $37 \mu \mathrm{m}$. Slide AMOCO: NSD-6 (-), E.F. U9/1.

7. Humboldt Formation, Eureka County, Nevada (loc. 30). Valve view. Diameter $43 \mu \mathrm{m}$. Slide AMOCO: PC-3-79 (+), E.F. H15/4.

8. Unnamed middle Miocene unit, Juliaetta, Nez Perce County, Idaho (loc. 32). Valve view. Diameter $29 \mu \mathrm{m}$. Slide USGS-D 5 XII 80-3 (2), E.F. K30/4.

9. Juliaetta, Nez Perce County, Idaho (loc. 32). Valve view. Scale bar in $\mu \mathrm{m}$. 
U.S. GEOLOGICAL SURVEY

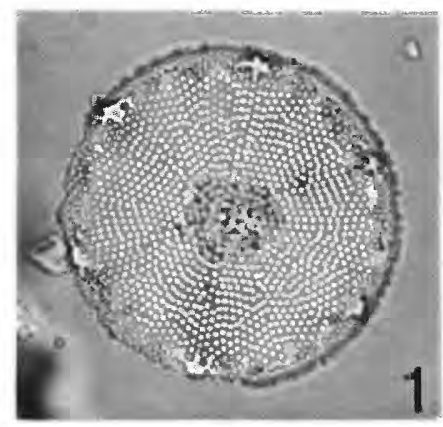

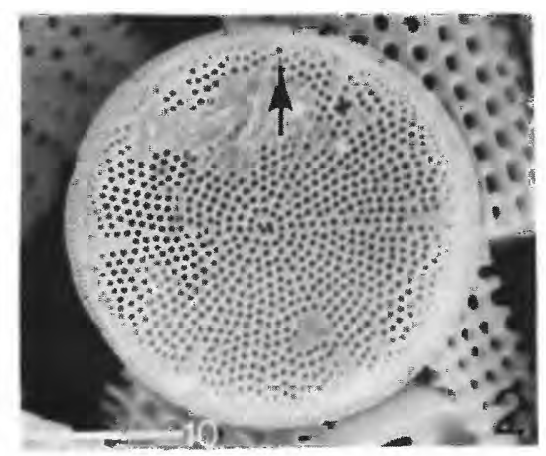

PROFESSIONAL PAPER 1543 PLATE 5

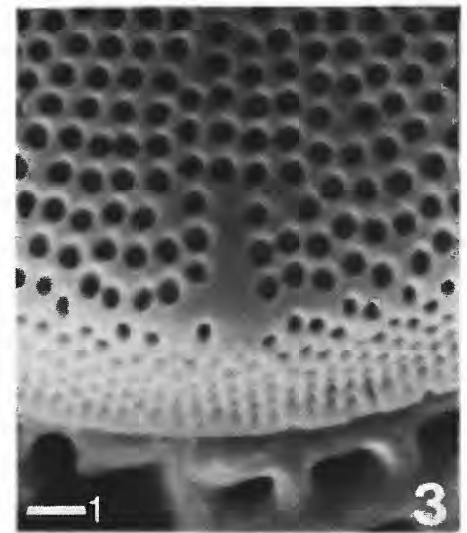

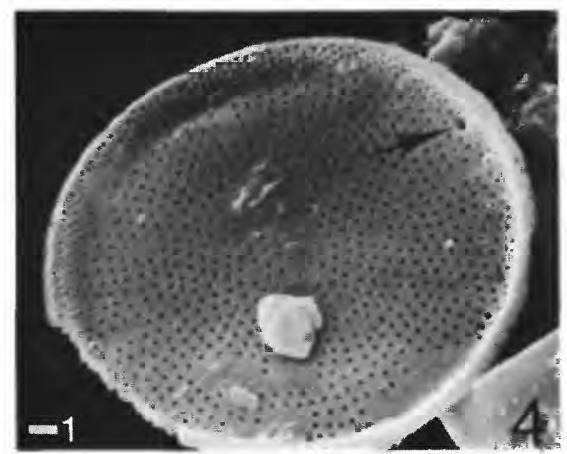
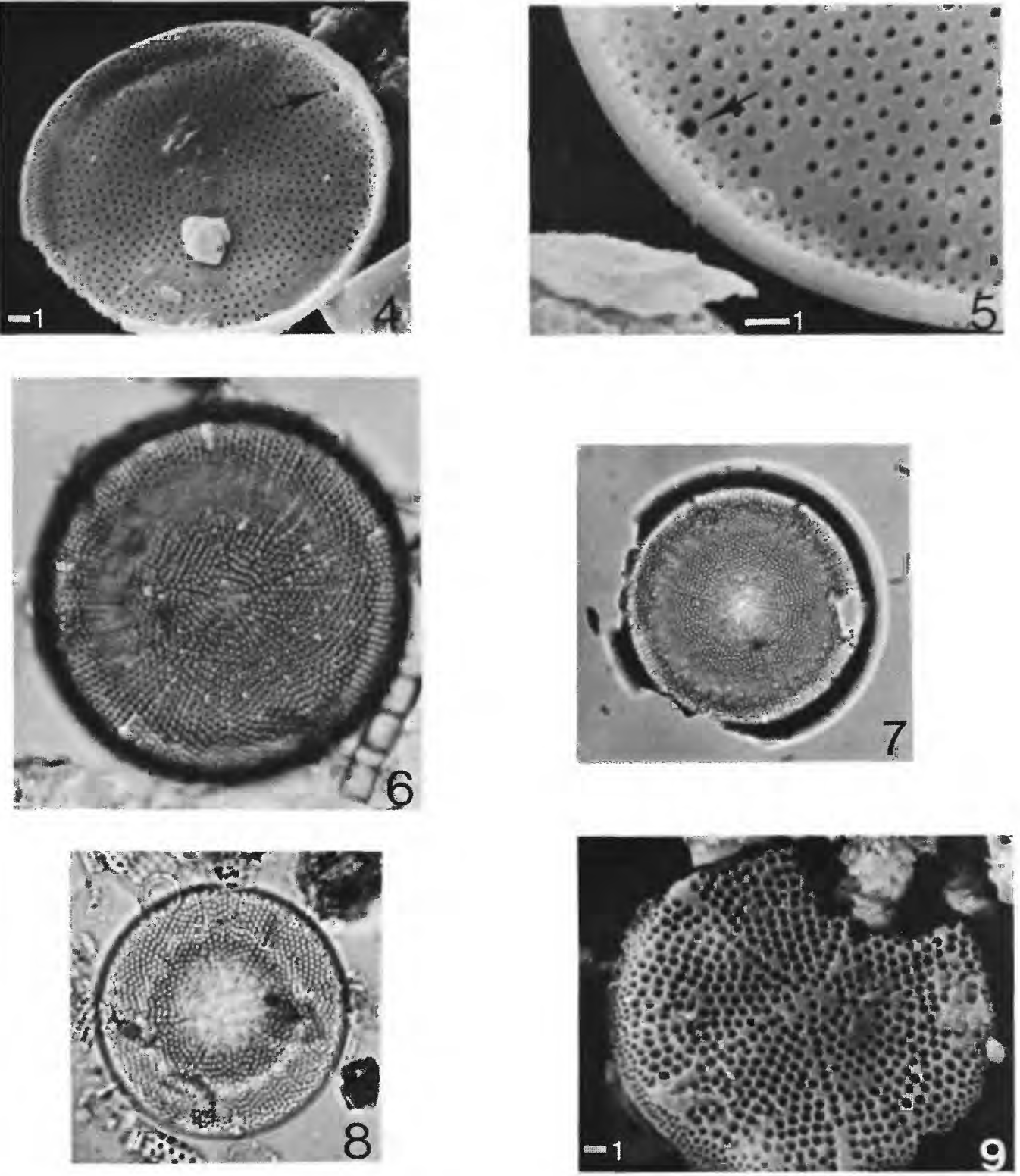


\section{PLATE 6}

Figures 1,2. Actinocyclus cf. A. cupreus (p. 7). Freshwater Miocene deposits, Yamato Bank, Sea of Japan. Valve views. Note the flat disk and long marginal hyaline stripes.

1. Core RC 12-394 $(600 \mathrm{~cm})$. Diameter $62 \mu \mathrm{m}$. Slide AMOCO: RC12-394 $600 \mathrm{~cm}(+)$, E.F. E33/4.

2. Core RC 12-394 $(600 \mathrm{~cm})$. Diameter $54 \mu \mathrm{m}$. Slide AMOCO: RC12-394 $600 \mathrm{~cm}(+)$. E.F. V10/2.

3-9. Actinocyclus ehrenbergii Ralfs in Pritchard (p. 7).

3-5. Quiburis Formation, Edgar Canyon, Pima County, Arizona (loc. 92). Scale bars in $\mu \mathrm{m}$.

3. Valve view showing large pseudonodule (arrow). Diameter $146 \mu \mathrm{m}$. Slide USGS-D 19 IV 80-3A (2), E.F. H36/3.

4. Internal detail of disk/mantle junction showing the closely spaced pores of labiate processes. Labiate processes are missing.

5. Closeup of labiate process.

6-9. Actinocyclus ehrenbergii Ralfs in Pritchard. Holocene marine sediment, Walvis Bay, Namibia. Scale bars in $\mu \mathrm{m}$.

6. Overview of valve interior showing marginal ring of labiate processes.

7,8. Closeup of labiate processes.

9. Internal view of pseudonodule (arrow). 
U.S. GEOLOGICAL SURVEY
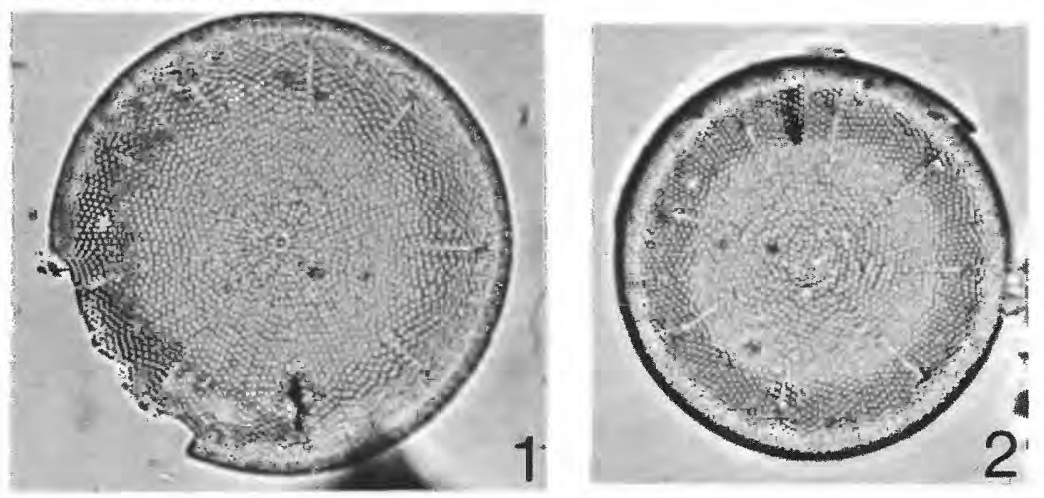

PROFESSIONAL PAPER 1543 PLATE 6

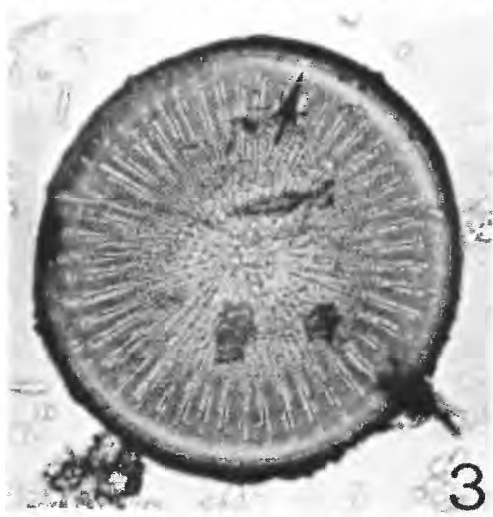

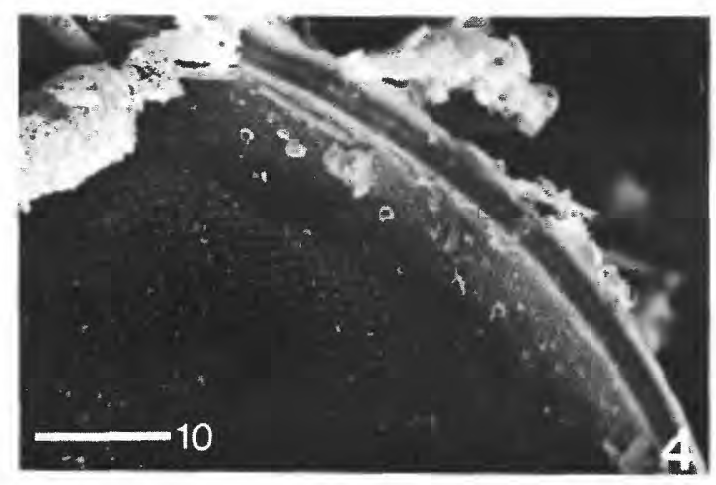
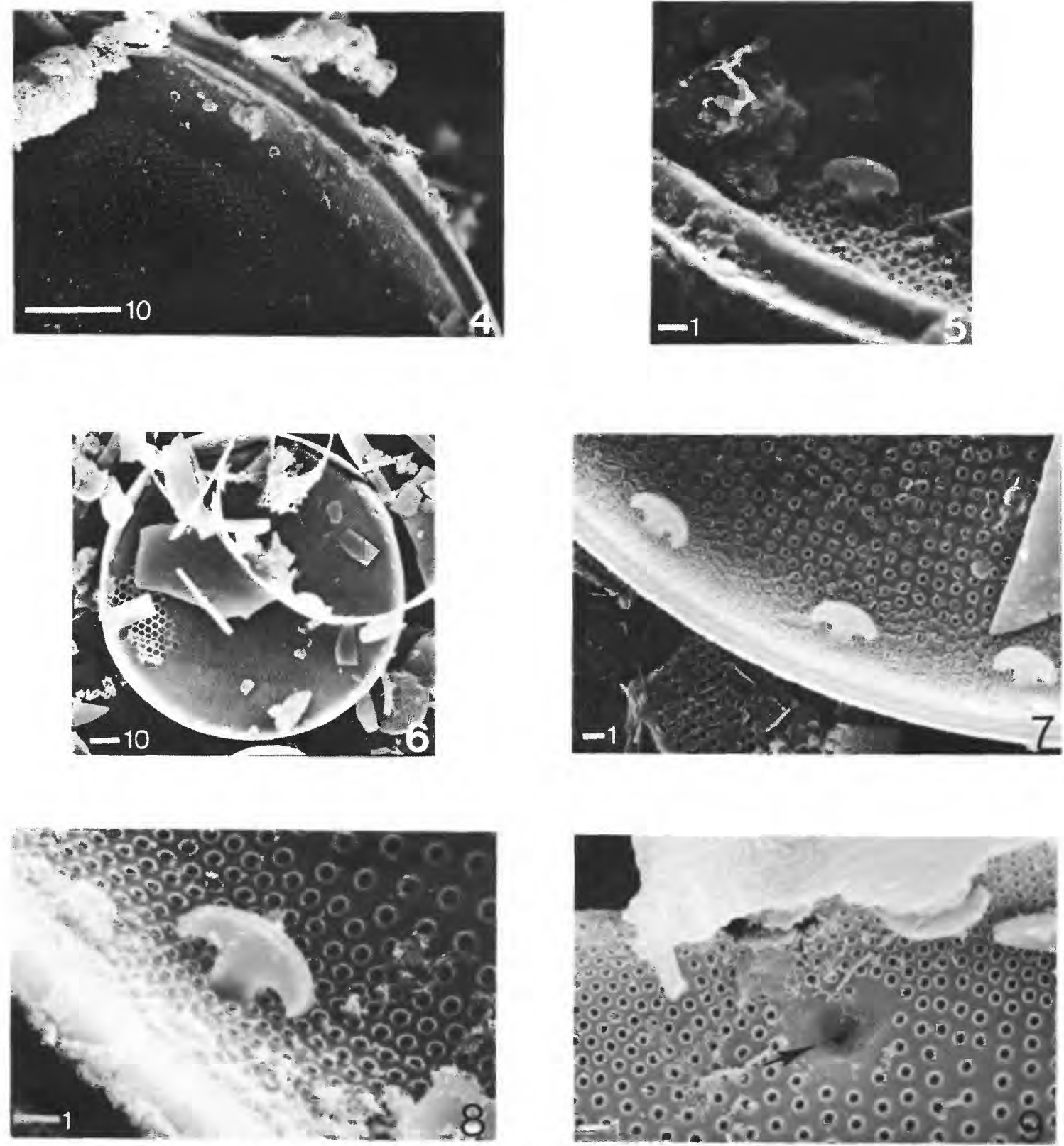

ACTINOCYCLUS sp.cf. A. CUPREUS AND ACTINOCYCLUS EHRENBERGII 


\section{PLATE 7}

Figures 1, 2. Actinocyclus ehrenbergii Ralfs in Pritchard (p. 7). Holocene marine sediment, Walvis Bay, Namibia. Scale bars in $\mu \mathrm{m}$.

1. Internal view of corroded pseudonodule (arrow).

2. External view of annulate pseudonodule (arrow) and exit pores of labiate processes.

3-8. Actinocyclus gorbunovii (Sheshukova) var. fossa Bradbury \& Krebs, var. nov.

(p. 7). Cedarville Formation, Forty-nine Camp. Washoe County, Nevada (loc. 69). Scale bars in $\mu \mathrm{m}$.

3. Valve view; note the pseudonodule (arrow), the lack of marginal tubular processes, and the concentric undulation of valve. Diameter $35 \mu \mathrm{m}$. Slide USGS-D 2 IX 87-3B (1). E.F. P35.

4. Overview of frustule showing steep mantle, concentric undulation, and position of pseudonodulc (arrow).

5. Detail of pseudonodule (arrow).

6. View of disk/mantle junction and pseudonodule (arrow). Note the circular moat-like structure that surrounds the pseudonodule.

7. Overview of valve interior showing labiate processes and pseudonodule (arrow).

8. Interior closeup of disk/mantle junction with labiate process and pseudonodule (arrow). 
U.S. GEOLOGICAL SURVEY
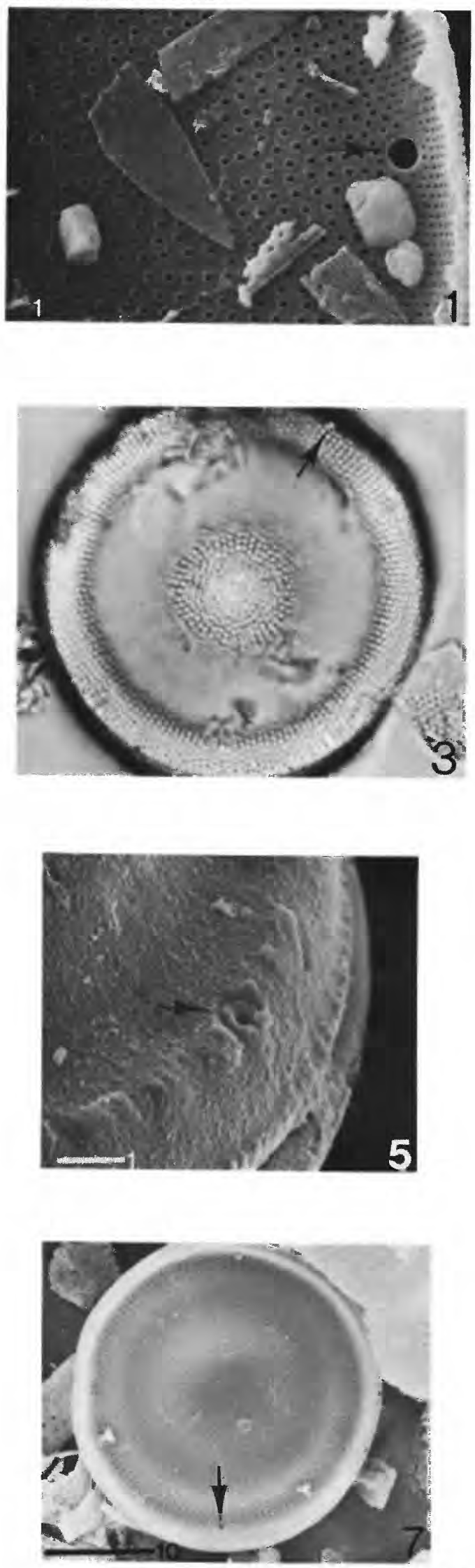

PROFESSIONAL PAPER 1543 PLATE 7
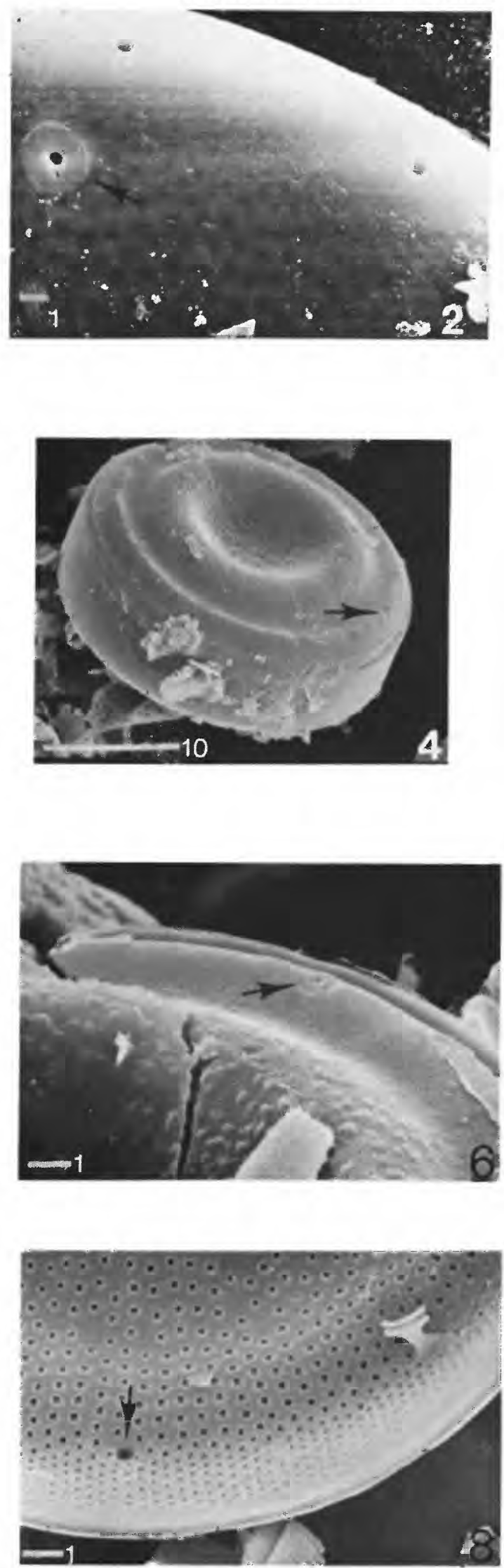


\section{Plate 8}

Figure 1. Actinocyclus kanitzii (Pant. \& Grun.) Schauderna (p. 3). Middle Miocene lacustrine and brackish water deposits, Szurdokpuspoki, Matra Mountains, Hungary. The fascicles are separated by hyaline stripes that run from the disk/mantle junction to the center of the disk. Diameter $74 \mu \mathrm{m}$. Slide USGS-D 3 IX 80-1B, E.F. F43/3.

2-6, 8-11. Actinocyclus krasskei (Krasske) Bradbury \& Krebs, nom. nov. (p. 9).

2. "Kieselgur" (diatomite) deposits of Miocene? age in Vogelsberg Range, Beuern, Germany. Different focus showing detail of slightly undulate valve center (a) and margin (b). Diameter $31 \mu \mathrm{m}$. Slide Krasske Collection, Natural History Museum, Kassel, Germany, Beuern \#3004.

3. Beuern, Germany. Valve vicw showing hyaline stripes and pseudonodule (arrow). Diameter $21 \mu \mathrm{m}$. Slide Krasske Collection, Natural History Museum, Kassel, Germany, Beuern \#3004.

4. Beuern, Germany. View of undulate valve showing disk/mantle junction and areolae on mantle arranged in quincunx pattern. Diameter $40 \mu \mathrm{m}$. Slide Krasske Collection, Natural History Museum, Kassel, Germany, Beuern \#3004.

5. Unnamed middle Miocene unit, Juliaetta, Nez Perce County, Idaho (loc. 32). Valve view. Diameter $29 \mu \mathrm{m}$. Slide USGS-D 5 XII 80-3 (2), E.F. D32/1.

6. Unnamed Miocene? unit, Arrow Junction, Nez Perce County, Idaho (loc. 72). Valve view. Diameter $27 \mu \mathrm{m}$. Slide AMOCO: USGS-DC\#2289, E.F. H30/1.

8. Juliaetta, Nez Perce County. Idaho (loc. 32). View of undulate valve. Diameter $40 \mu \mathrm{m}$. Slide USGS-D 5 XII 80-3 (2). E.F. Q38.

9, 10. Squaw Creck Member, Ellensburg Formation. Yakima County, Washington (loc. 49). Interior of valve showing long-stemmed labiate processes and pseudonodulc (arrow). Scale bars in $\mu \mathrm{m}$.

11. Mascall Formation, Vinegar Creck, Grant County, Oregon (loc. 88). Interior of valve showing ring of long-stemmed labiate processes. Scale bars in $\mu \mathrm{m}$.

7. Actinocyclus tubulosus Khursevich. (p. 13). Squaw Creek Member, Ellensburg Formation, Yakima County, Washington (loc. 49). Valve vicw. Diameter $27 \mu \mathrm{m}$. Slide USGS-D 26 II 79-2A (3), E.F. N47/4. 

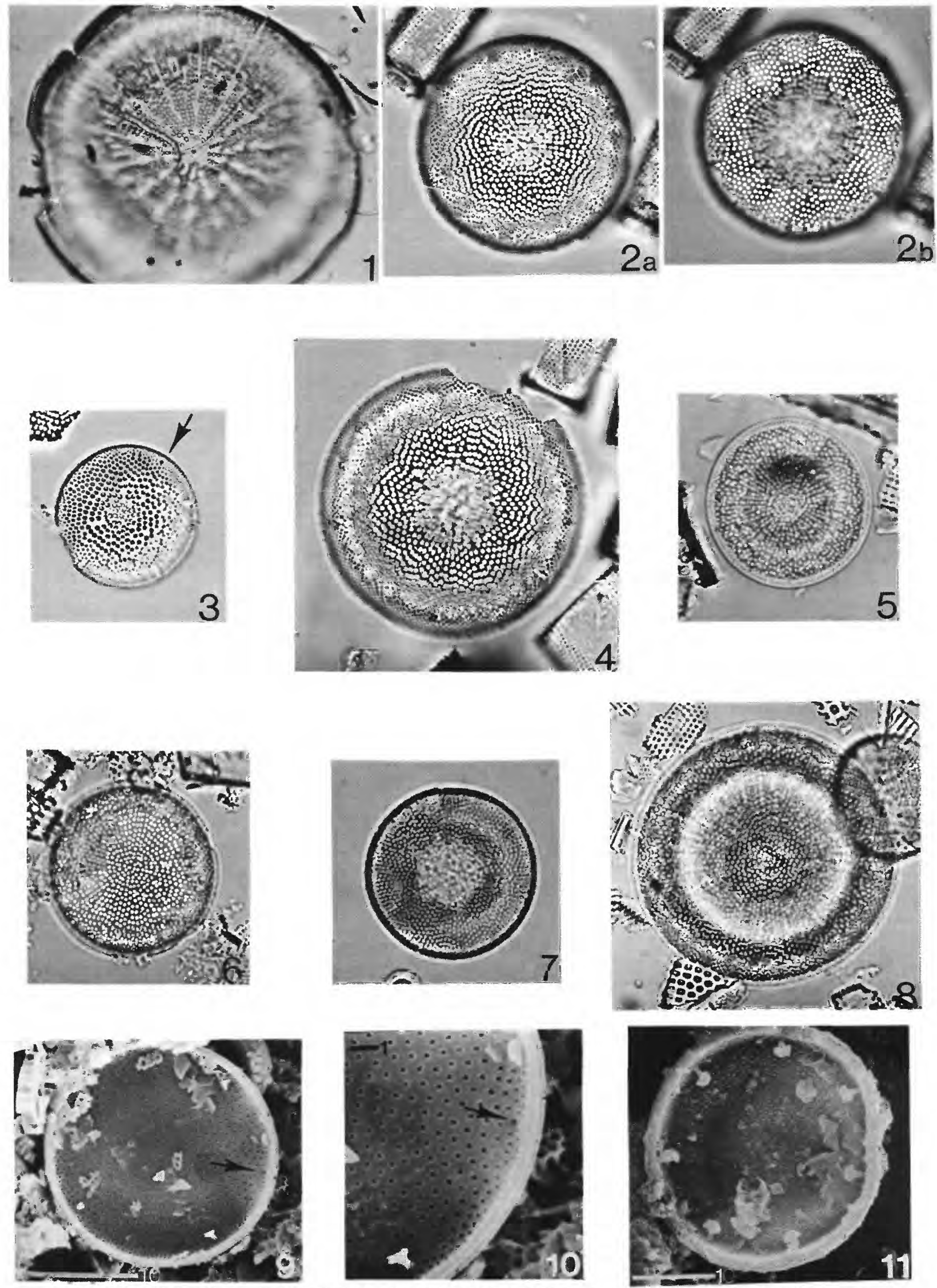

ACTINOCYCLUS KANITZII, ACTINOCYCLUS KRASSKEI, AND ACTINOCYCLUS TUBULOSUS 


\section{PLATE 9}

Figure 1. Flat forms of Actinocyclus krasskei (Krasske) Bradbury \& Krebs, nom. nov. (p. 9). Mascall Formation, Vinegar Creek, Grant County, Oregon (loc. 88). Closeup of labiate process. Scale bars in $\mu \mathrm{m}$.

2,3. Undulate forms of Actinocyclus krasskei (Krasske) Bradbury \& Krebs, nom. nov. (p. 9). Squaw Creek Member, Ellensburg Formation, Yakima County, Washington (loc. 49). Scale bars in $\mu \mathrm{m}$.

2. Closeup of labiate process.

3. Valve interior showing position of pseudonodule (arrow).

4-6. Actinocyclus motilis Bradbury \& Krebs, sp. nov. (p. 10).

4. Esmeralda Formation, Cedar Mountain, Mineral County, Nevada (loc. 22). Note the truncation of sinuous rows of areolae by other rows. Diameter $23 \mu \mathrm{m}$. Slide USGS-D 23 I $81-10$ (1), E.F. L34/2.

5. Unnamed middle Miocene unit. Augusta Mountains. Churchill County, Nevada (loc. 4). Focus on valve margin (a) and center (b). Diameter $42 \mu \mathrm{m}$. Slide AMOCO: AMS-1-1(-), E.F. M34/2.

6. Unnamed middle Miocene unit. Goose Creek, Baker County, Oregon (loc. 27). Focus on valve margin (a) and center (b). Diameter $46 \mu \mathrm{m}$. Slide USGS-D 10 VI 78-2B (3), E.F. L24/4. 
U.S. GEOLOGICAL SURVEY
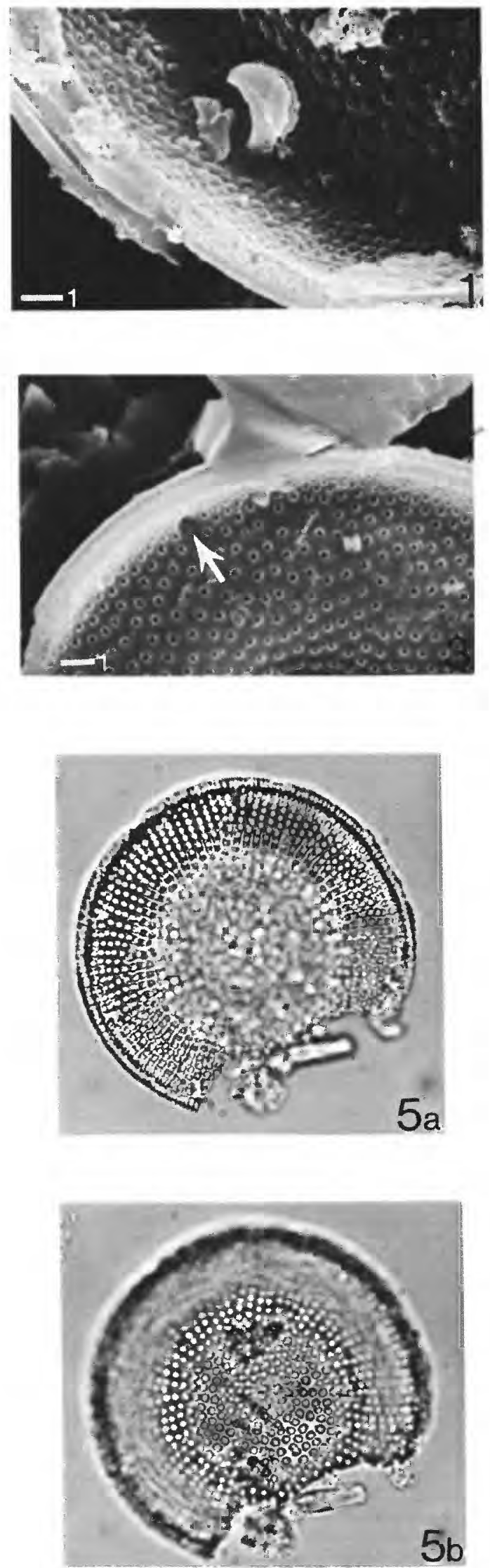

PROFESSIONAL PAPER 1543 PIATE 9
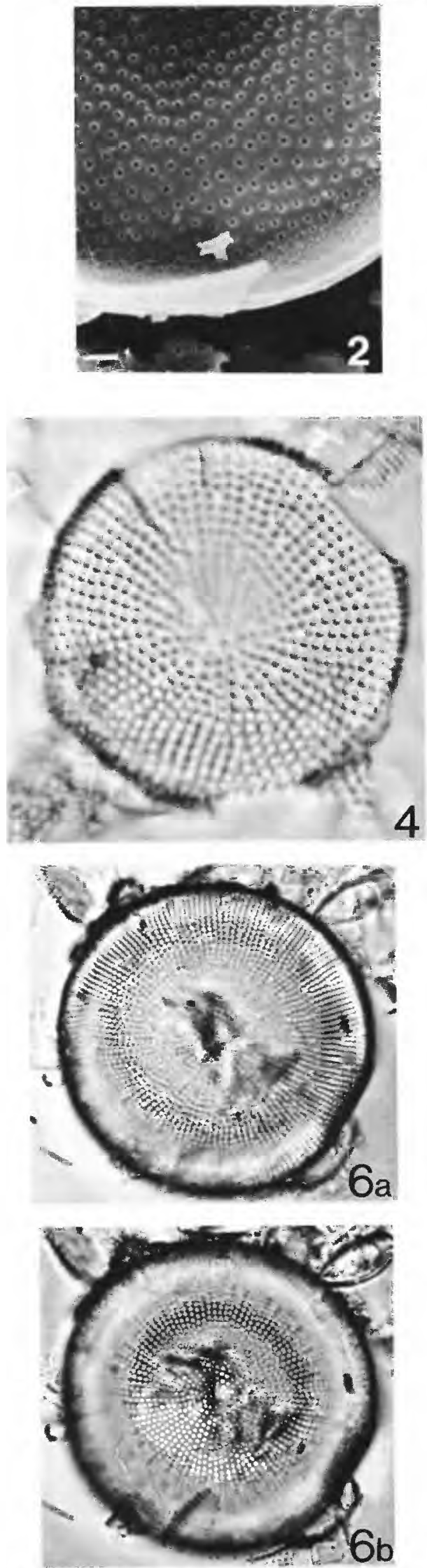


\section{PLATE 10}

Figure 1-12. Actinocyclus motilis Bradbury \& Krebs, sp. nov. (p. 10). Scale bars in $\mu \mathrm{m}$.

1. Squaw Creek Member, Ellensburg Formation, Yakima County, Washington (loc. 49). Diameter $34 \mu \mathrm{m}$. Slide USGS-D 27 II 79-1, E.F. R31/4.

2-8. Esmeralda Formation, Cedar Mountain. Mineral County, Nevada (loc. 22).

2. Valve view showing separation of valve from intercalary bands. Arrow marks probable pseudonodule.

3. Valve interior showing position of pseudonodule (arrow).

4. Detail of pseudonodule (arrow) showing pore structure.

5,6 . Broken stumps of labiate processes. Arrow marks location of probable pseudonodule in figure 6.

7, 8. Closeups of long-stemmed labiate processes.

9-12. Squaw Creek Member, Ellensburg Formation, Yakima County. Washington (loc. 49).

9. Exterior of valve showing concentric undulation and interdigitation of rows of areolae at the valve margin. Arrow marks probable pseudonodule.

10. Girdle view of frustule.

11. View of valve interior showing a marginal ring of long-stemmed labiate processes.

12. Closeup of labiate processes. 
U.S. GEOLOGICAL SURVEY
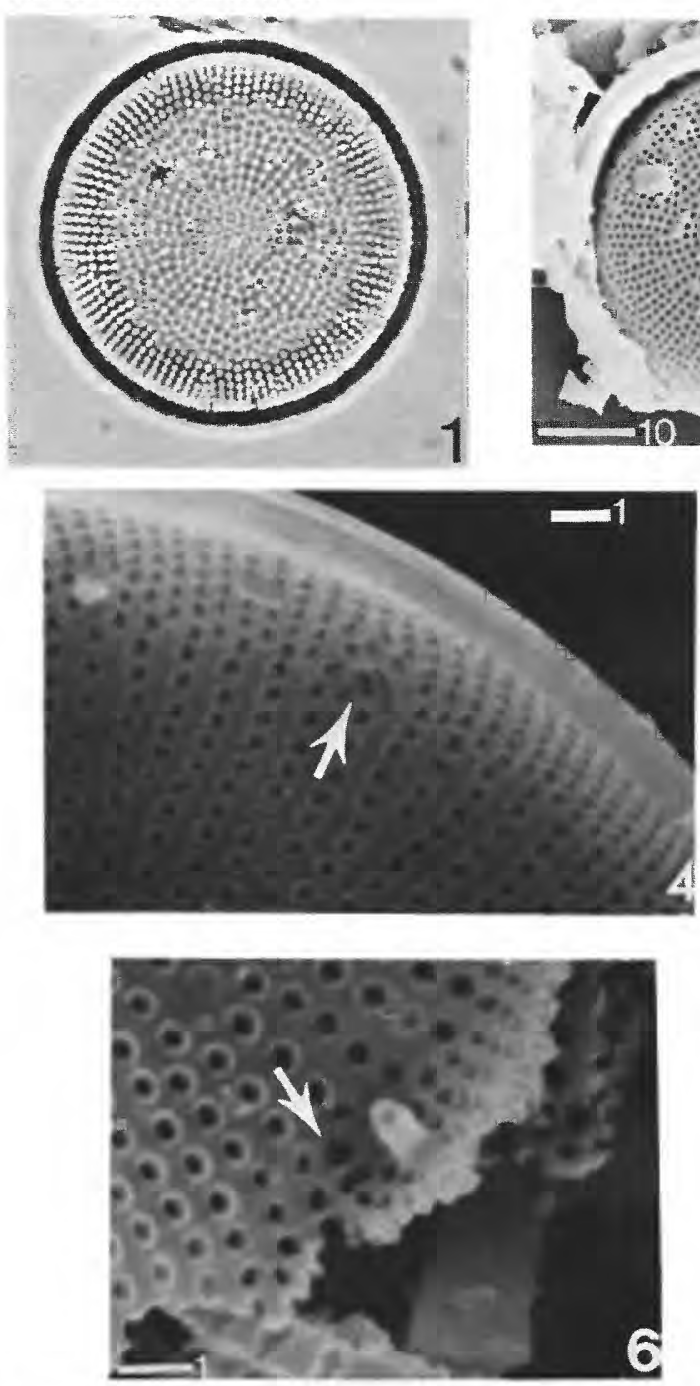

PROFESSIONAL PAPER 1543 PLATE 10
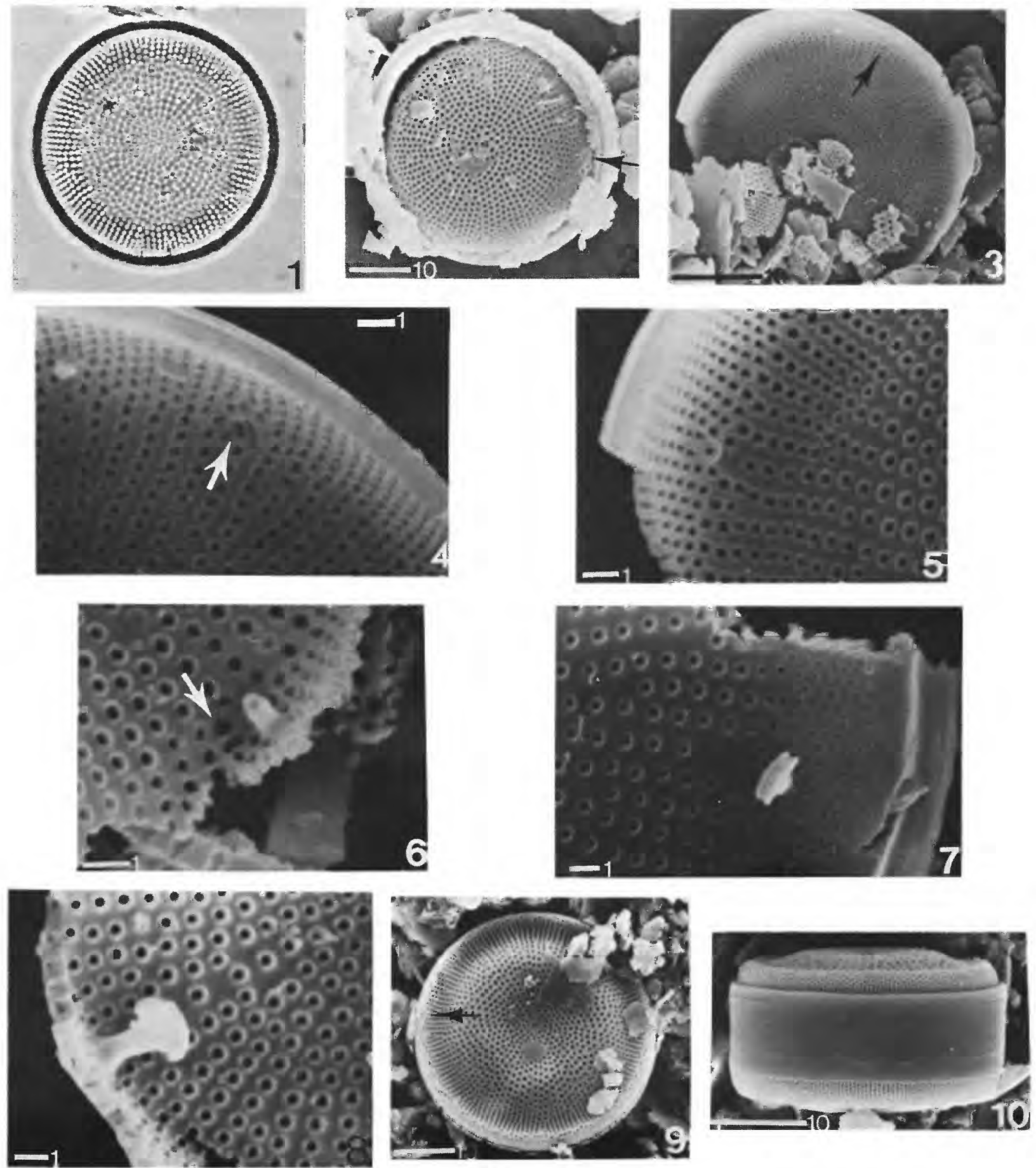

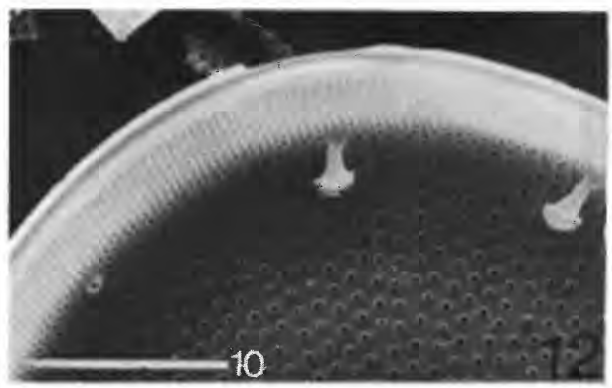




\section{PLATE 11}

Figure 1. Actinocyclus motilis Bradbury \& Krebs, sp. nov. (p. 10). Squaw Creek Member, Ellensburg Formation, Yakima County, Washington (loc. 49). Detail of valve disk/ mantle junction showing pseudonodule (arrow) and hyaline stripe with exit pore. Scale bar in $\mu \mathrm{m}$.

2-8. Actinocyclus nebulosus Bradbury \& Krebs. (p. 11). Scale bars in $\mu \mathrm{m}$.

2. Esmeralda Formation, Black Spring, Nye County, Nevada (loc. 93). Valve view. Diameter $67 \mu \mathrm{m}$. Slide USGS-D 26 XII 86-2A (1), E.F. H38/1.

3. Esmeralda Formation, Black Spring, Nye County, Nevada (loc. 93). Valve view. Diameter $77 \mu \mathrm{m}$. Slide USGS-D 26 XII 86-2A (1), E.F. G36/3.

4. Buffalo Canyon Formation, Buffalo Canyon, Churchill County, Nevada (loc. 6). Valve view. Diameter $83 \mu \mathrm{m}$. Slide AMOCO: Buffalo Canyon, E.F. E6/4.

5. Esmeralda Formation, Cedar Mountain, Nye County, Nevada (loc. 74). Arrow marks probable pseudonodule. Diameter $67 \mu \mathrm{m}$. AMOCO: USGS-DC \#3394 (3). E.F. M42/2.

6-8. Esmeralda Formation. Black Spring, Nye County, Nevada (loc. 93). Views of valve interior; arrow indicates position of pscudonodule. 
U.S. GEOLOGICAL SURVEY
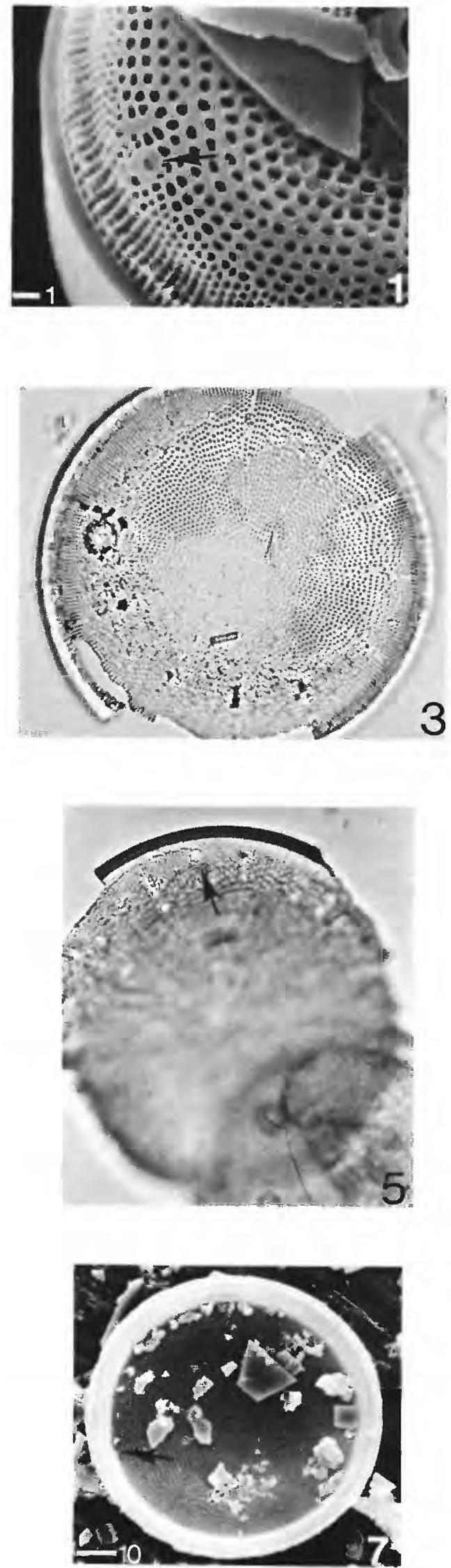

PROFESSIONAL PAPER 1543 PLATE 11
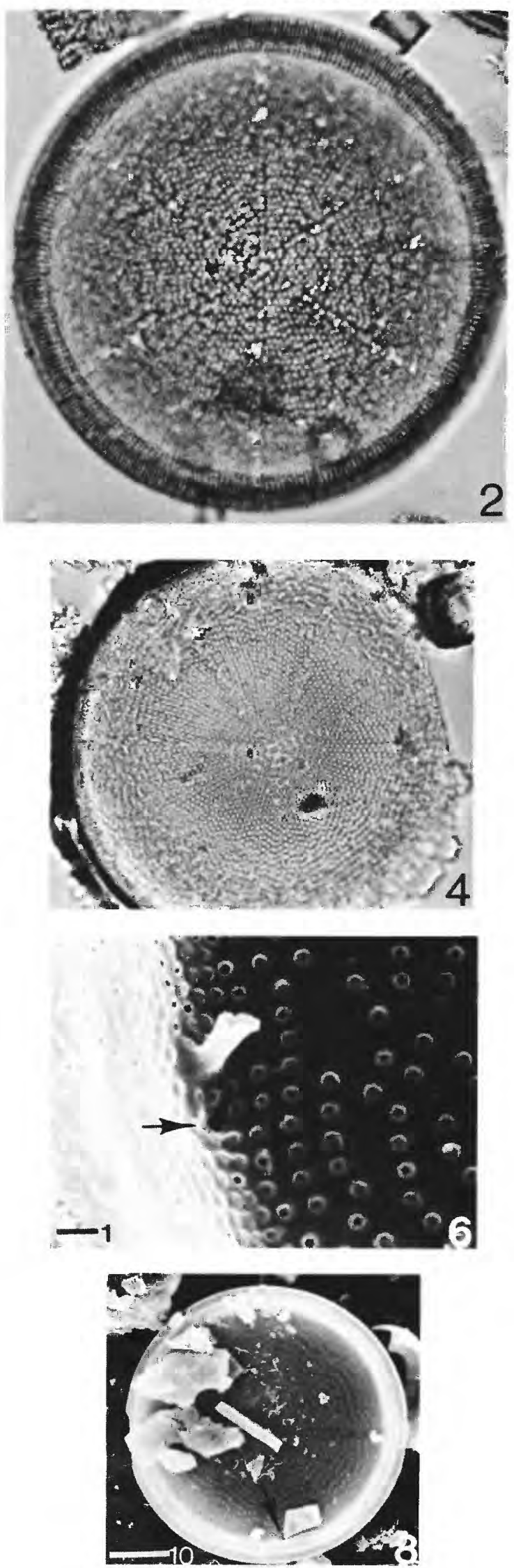


\section{PLATE 12}

Figure 1. Actinocyclus nebulosus Bradbury \& Krebs, sp. nov. (p. 11). Esmeralda Formation, Black Spring, Nye County, Nevada (loc. 93). Interior detail of mantle/disk junction showing short-stemmed broad labiate process and position of pseudonodule (arrow). Scale bar in $\mu \mathrm{m}$.

2-5. Actinocyclus normanii f. subsalsa (Juhl.-Dannf.) Hustedt. (p. 3). Holocene lake sediment, Saginaw Bay, Lake Huron, Michigan. Scale bars in $\mu \mathrm{m}$.

2. Valve view. Diameter $33 \mu \mathrm{m}$. Slide USGS-D 24 II 82-1 (1), E.F. P31/1.

3. Valve view. Diameter $37 \mu \mathrm{m}$. Slide USGS-D 24 II 82-1 (1), E.F. N39/1-2.

4, 5. Valve views. Arrows indicate position of pseudonodule.

6, 7. Actinocyclus pinnulus Bradbury \& Krcbs, sp. nov. (p. 11). Hole-in-the-Wall Diatomite, Gooding County, Idaho (loc. 90).

6. Valve view. Arrows indicate positions of marginal flanged tubular processes. Diameter $61 \mu \mathrm{m}$. Slide USGS-D 21 VI 88-1 (1), E.F. N29.

7. Valve view. Arrows highlight marginal hyaline stripes. Diameter $66 \mu \mathrm{m}$. Slide USGS-D 21 VI 88-1 (1), E.F. P43. 
U.S. GEOLOGICAL SURVEY
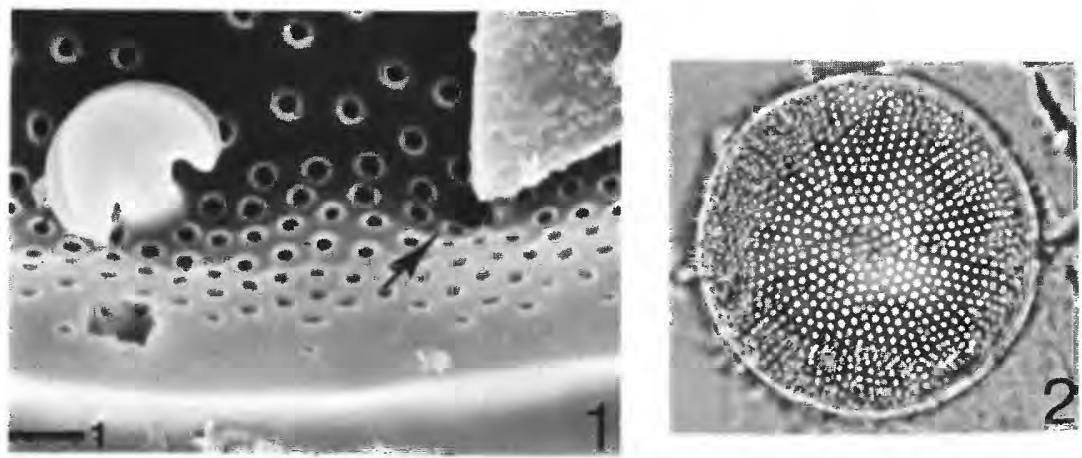

PROFESSIONAL PAPER 1543 PLATE 12

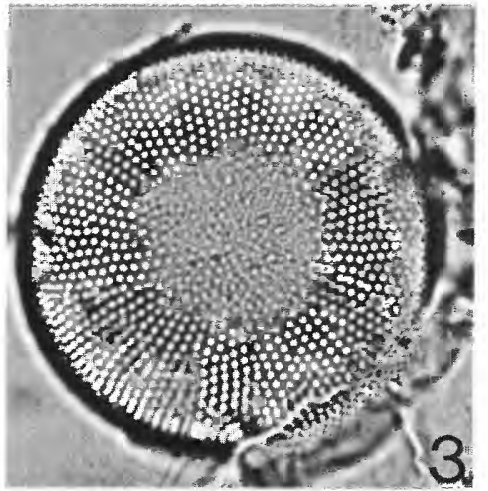

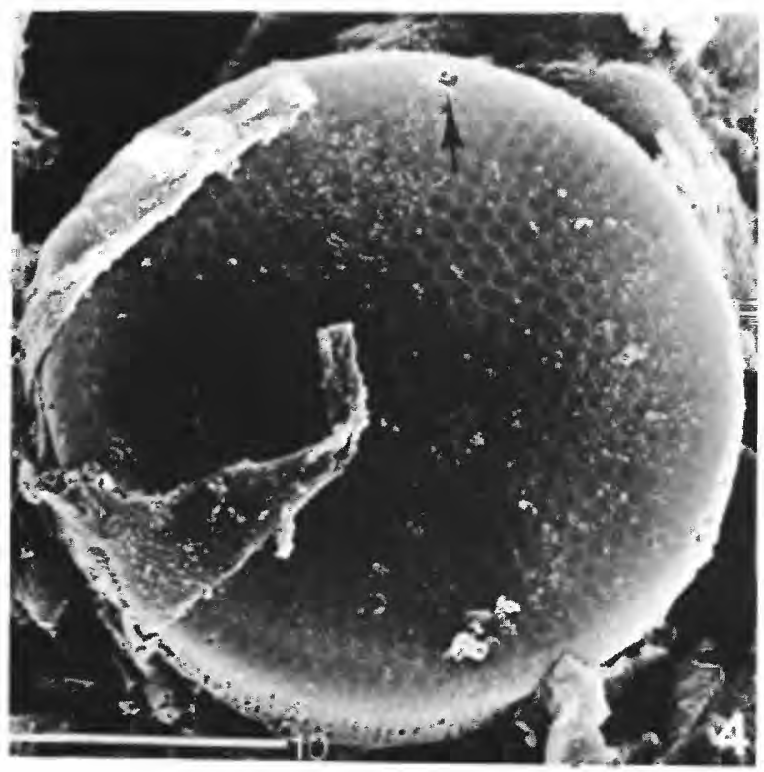
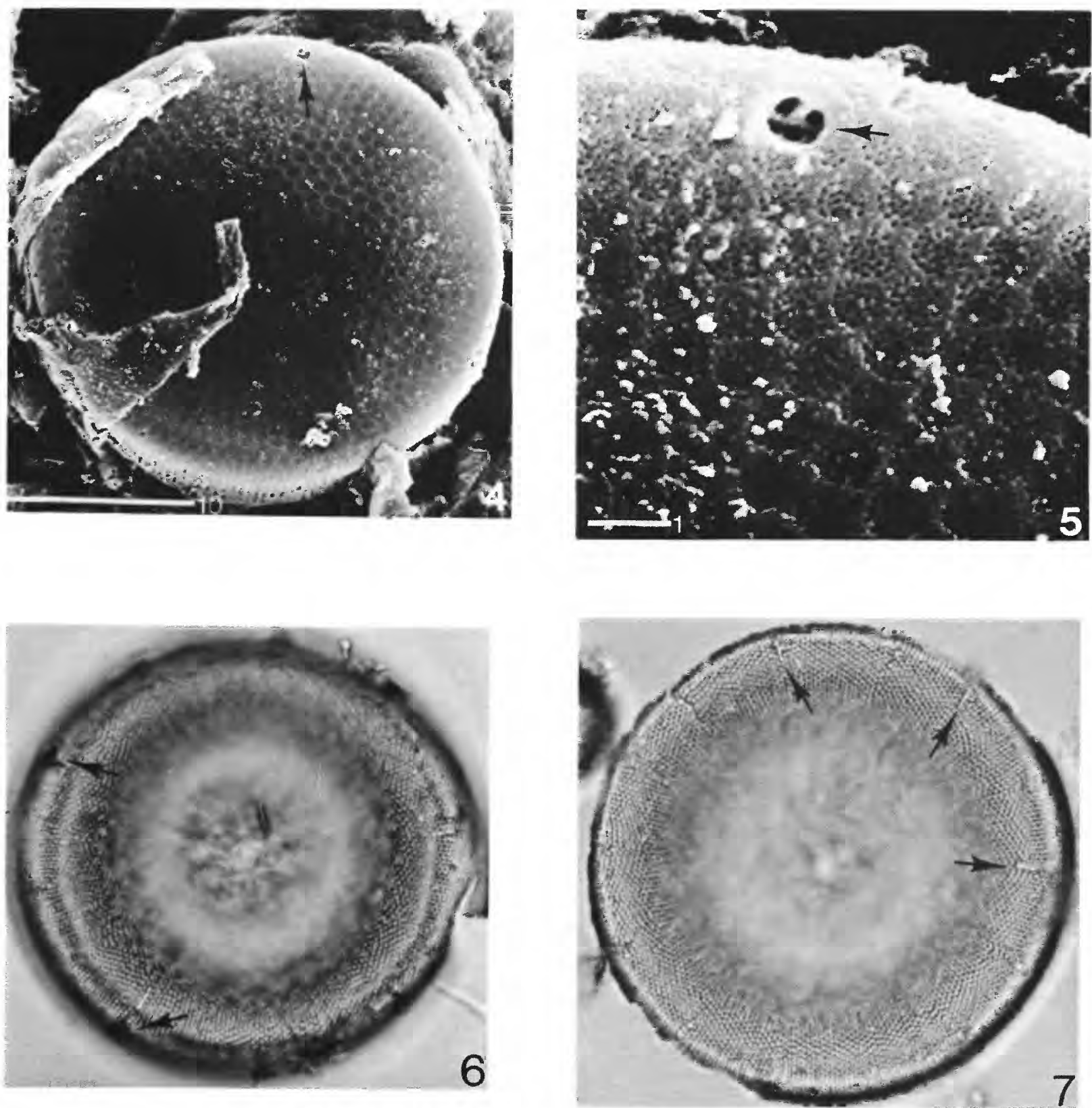

ACTINOCYCLUS NEBULOSUS, ACTINOCYCLUS NORMANII f. SUBSALSA,

AND ACTINOCYCLUS PINNULUS 


\section{PLATE 13}

Figures 1-5. Actinocyclus pinnulus Bradbury \& Krebs, sp. nov. (p. 11). Hole-in-the-Wall Diatomite, quarry, Gooding County, Idaho (loc. 90). Scale bars in $\mu \mathrm{m}$.

1. Valve view. Arrows highlight marginal flanged tubular processes. Diameter $66 \mu \mathrm{m}$. Slide USGS-D 21 VI 88-1 (1), E.F. P43.

2,3. Valve view. Arrows indicate the position of a marginal flanged tubular process

4. Overview of valve interior showing a ring of marginal short-stemmed labiate processes and the pseudonodule (arrow).

5. Closeup of labiate processes and the pseudonodule (arrow).

6. Actinocyclus sp. cf. A. pinnulus (p. 12). Amoco Becharof No. 1 well, depth 3220-3250 feet, Alaska Peninsula, Alaska (loc. 112). Focus on valve margin (a) and center (b). Arrow indicates the position of the pseudonodule. Diameter $40 \mu \mathrm{m}$. Slide AMOCO: Becharof 3220-3250 ft. (-), E.F. V22/3.

7. Actinocyclus theleus Bradbury \& Krebs, sp. nov. (p. 12). "Clarkia Lake deposits," Emerald Creek, Benewah County, Idaho (loc. 21). Valve view; pseudonodule indicated by arrow. Diameter $25 \mu \mathrm{m}$. Slide USGS-D 5 XII 80-4 (2), E.F. P28/2. 

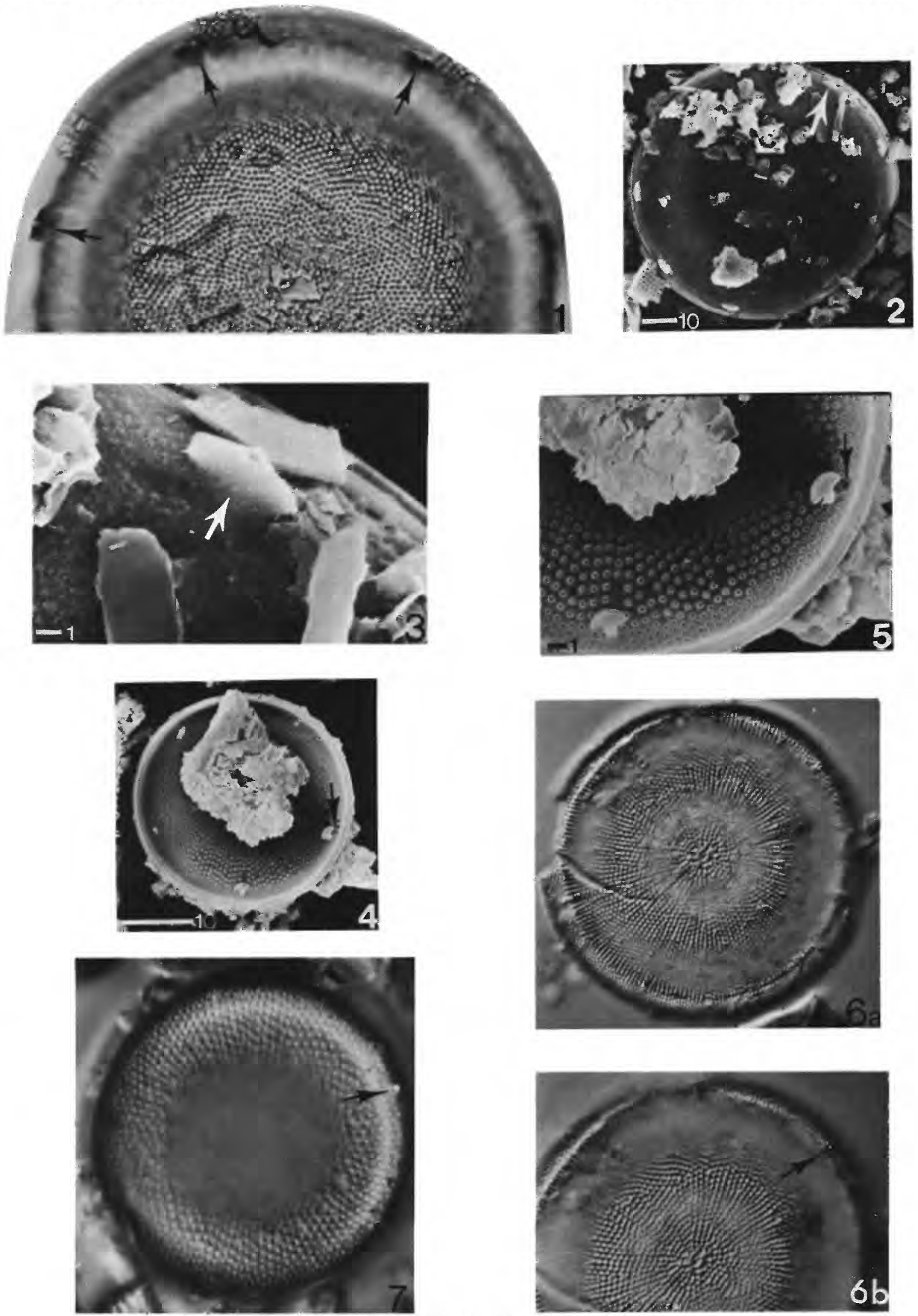

ACTINOCYCLUS PINNULUS, ACTINOCYCLUS sp.cf. A. PINNULUS, AND ACTINOCYCLUS THELEUS 


\section{PLATE 14}

Figures 1-4. Actinocyclus theleus Bradbury \& Krebs, sp. nov. (p. 12). Scale bars in $\mu \mathrm{m}$.

1. Unnamed middle Miocene unit, Oviatt Creek, Clearwater County, Idaho (loc. 43). Valve view. Note arrow to the nipple-like marginal process(es) (mp). Pseudonodule is indicated by other arrow (pn). Diameter $34 \mu \mathrm{m}$. Slide USGS D 5 XII 80-1 (1), E.F. V39/1.

2. "Clarkia Lake deposits," Emerald Creek, Benewah County, Idaho (loc. 21). Valve view of exterior surface showing the pseudonodule (pn) and marginal process (es) (mp).

3. Emerald Creek, Benewah County, Idaho (loc. 21). Closeup of disk/mantle junction showing marginal process $(\mathrm{mp})$ and pseudonodule $(\mathrm{pn})$.

4. Emerald Creek, Benewah County, Idaho (loc. 21). Interior view with two labiate processes, and the pseudonodule (arrow).

5, 6. Coscinodiscus (=Actinocyclus) variabilis sensu Krasske. (p. 3). Unnamed Miocene? unit in the Vogelsberg Range, Ruckers. Germany.

5. Valve view. Diameter $37 \mu \mathrm{m}$. Slide Krasske Collection, Natural History Museum, Kassel, Germany, Ruckers \#2996.

6. Focus on the valve disk (a) and mantle (b). Diameter $52 \mu \mathrm{m}$. Slide Krasske Collection, Natural History Museum, Kassel, Germany, Ruckers \#2996.

7, 8. Actinocyclus venenosus Bradbury \& Krebs, sp. nov. (p. 13). Poison Creek Formation, Reynolds Creek, Owyhee County, Idaho (loc. 44).

7. Valve view showing long, pointed hyaline stripes. Diameter $71 \mu \mathrm{m}$. Slide AMOCO: IO-23-2(+), E.F. Q22/4.

8. Valve view of large specimen. Note the dash-like hyaline stripes. Diameter $125 \mu \mathrm{m}$. Slide AMOCO: IO-23-6(+), E.F. F35/4. 

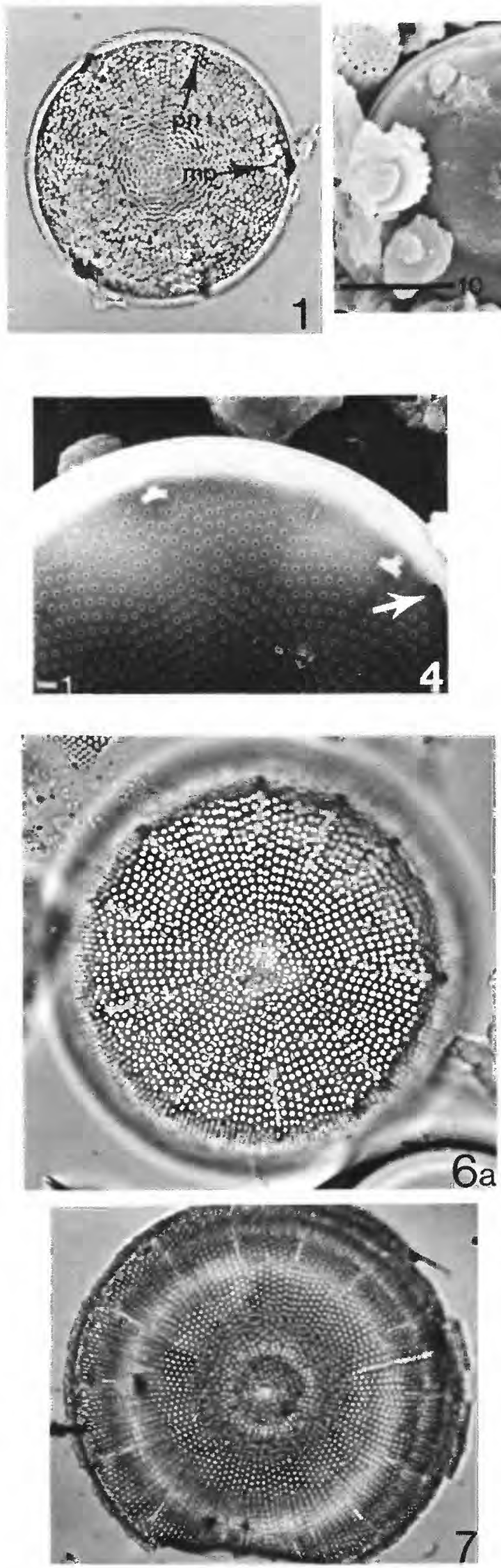
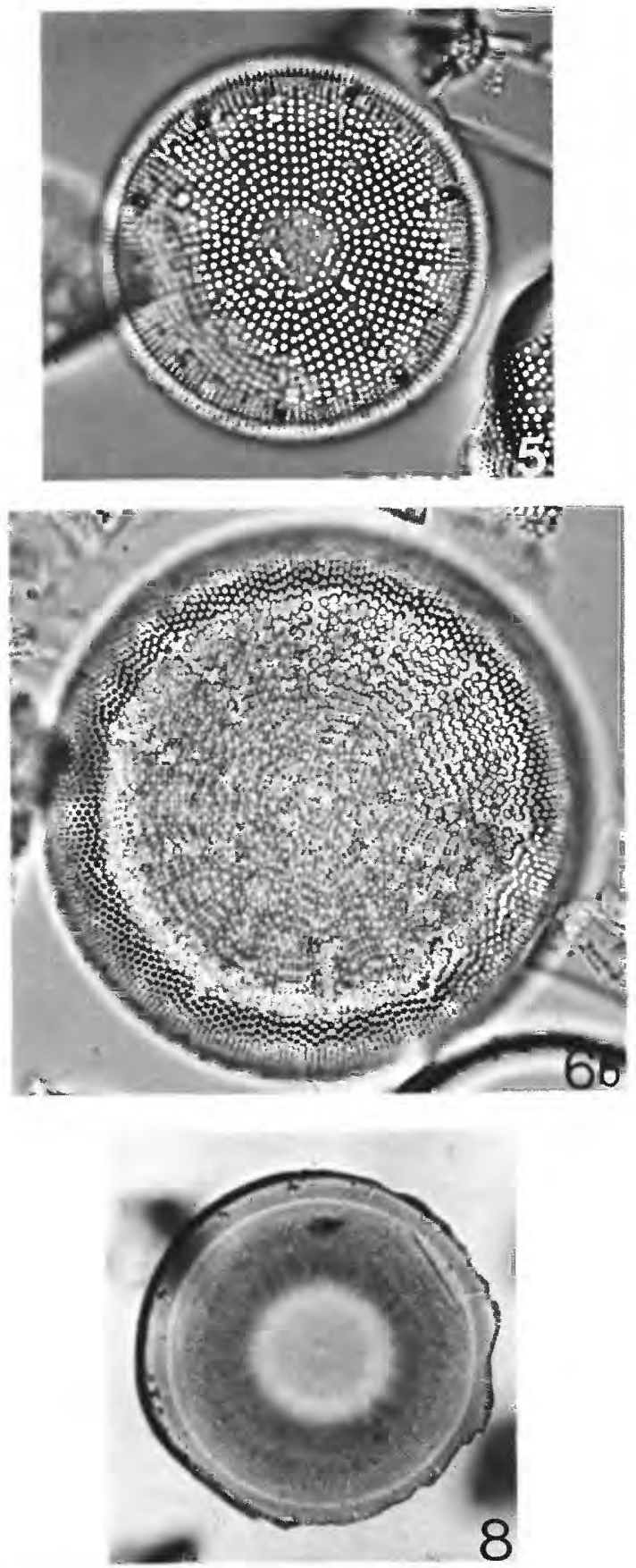

ACTINOCYCLUS THELEUS, COSCINODISCUS (=ACTINOCYCLUS) VARIABILIS, AND ACTINOCYCLUS VENENOSUS 


\section{PLATE 15}

Figures 1-6. Actinocyclus venenosus Bradbury \& Krebs, sp. nov. (p. 13). Scale bars in $\mu \mathrm{m}$.

1. Poison Creek Formation, Reynolds Creek. Owyhee County, Idaho (loc. 44). Valve view showing polygonal areolae. concentric undulation of the valve face, and pointed marginal hyaline stripes. Diameter $66 \mu \mathrm{m}$. Slide USGS-D 11 VI 78-1A (2), E.F. G35.

2, 3. Idaho Group, Washington County, Idaho (loc. 31). View of exterior valve surface showing the exit pores of the labiate processes and marginal hyaline stripes.

4. Idaho Group, Washington County, Idaho (loc. 31). Detail of valve disk/ mantle junction showing exit pores, hyaline stripes, and hyaline rim.

5. Idaho Group, Washington County, Idaho (loc. 31). View of interior surface. Note the ring of marginal short-stemmed, broadly flanged labiate processes.

6. Poison Creek Formation, Reynolds Creek, Owyhee County, Idaho (loc. 44). Closeup of labiate process. Arrow indicates the position of pseudonodule. 
U.S. GEOLOGICAL SURVEY
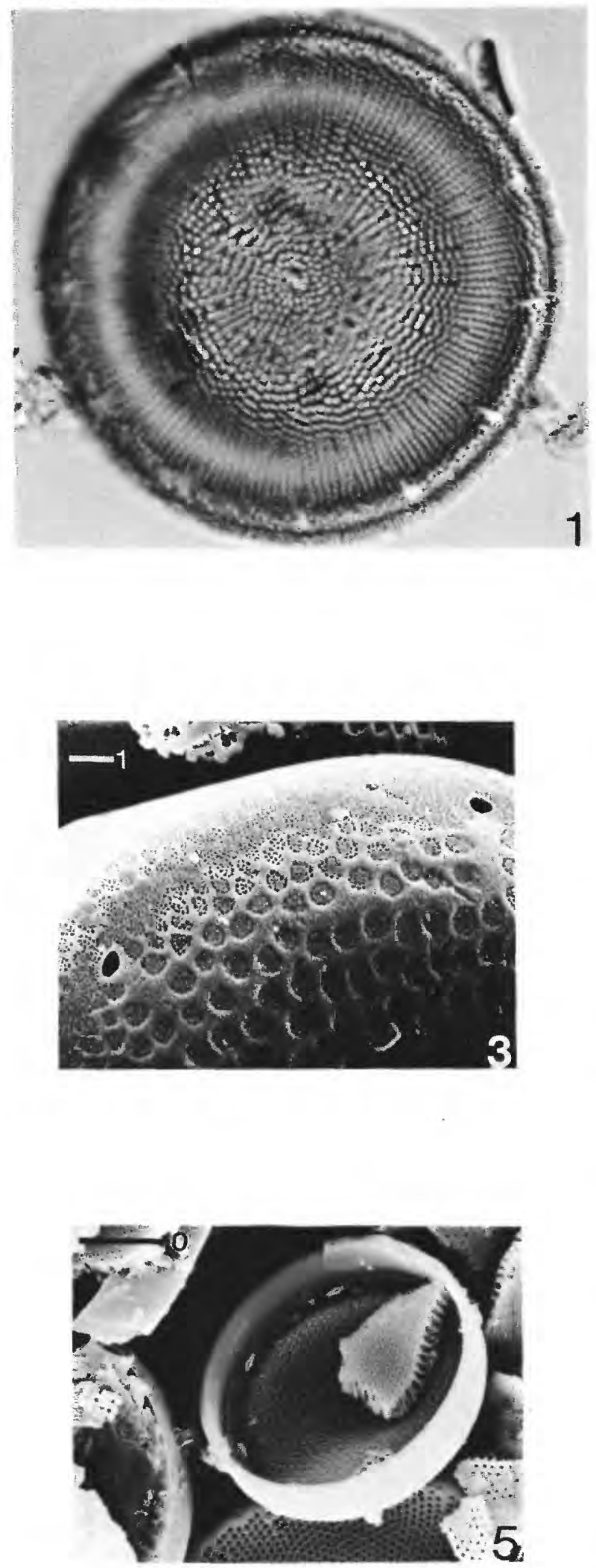

PROFESSIONAL PAPER 1543 PLATE 15
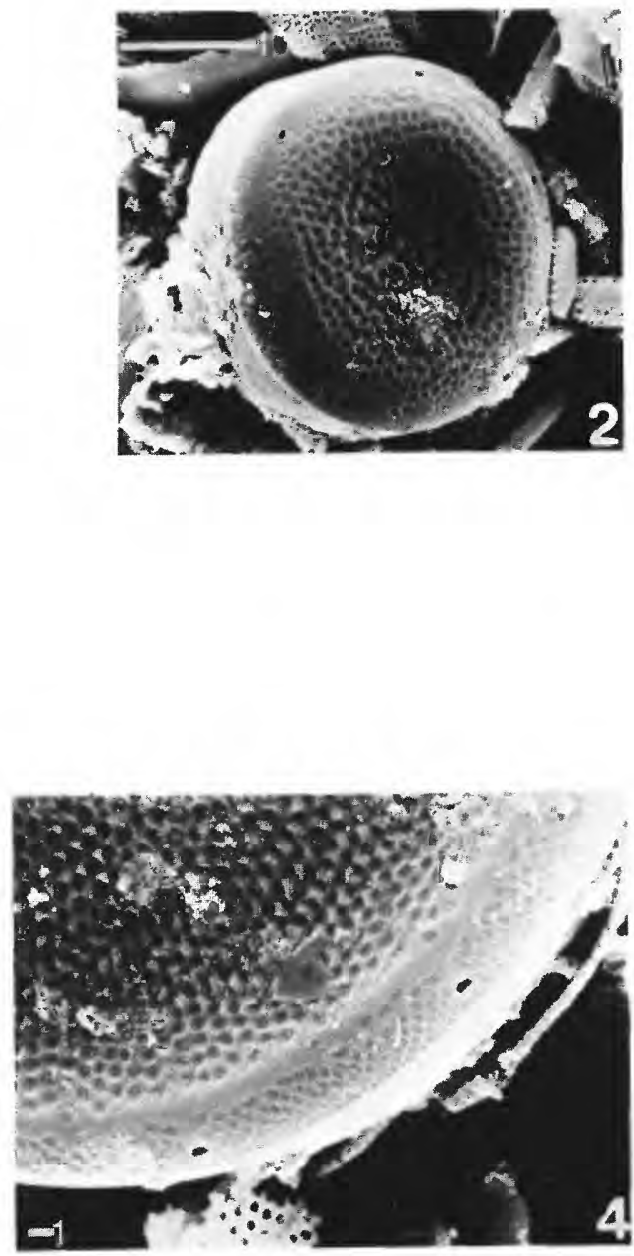


\section{Geologic Ranges of Lacustrine Actinocyclus Species, Western United States}

By William N. Krebs and J. Platt Bradbury

Preliminary geologic ranges of lacustrine species of the Western United States determined from radiometrically dated outcrops of diatomites and diatomaceous sediments from Nevada, California, Washington, Oregon, and Idaho

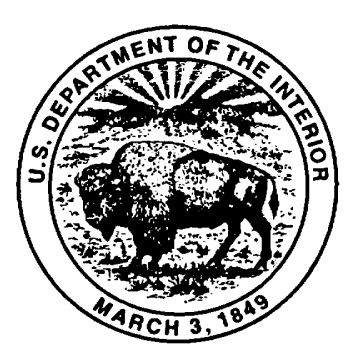




\section{CONTENTS}

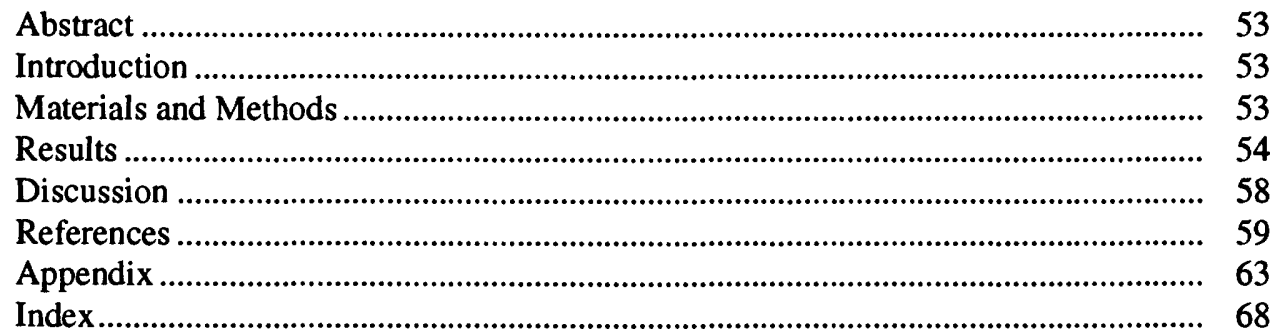

\section{ILLUSTRATIONS}

Figure 1. Biochronology and general relative diversities of six lacustrine diatom genera, Western United States.......... 54

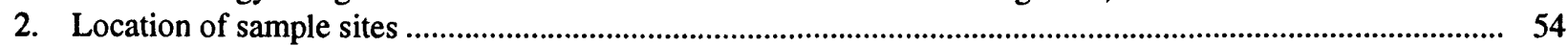

3. Preliminary range chart of obligate lacustrine Actinocyclus species, Western United States ........................... 56 


\title{
GEOLOGIC RANGES OF LACUSTRINE ACTINOCYCLUS SPECIES, WESTERN UNITED STATES
}

\author{
By William N. Krebs ${ }^{1}$ and J. Platt Bradbury ${ }^{2}$
}

\begin{abstract}
In the Western United States, twelve obligate freshwater species of Actinocyclus Ehrenberg are restricted to the early and middle Miocene. Maximum diversity (11 species) was attained during the early middle Miocene, before the appearance of obligate lacustrine genera of the family Thalassiosiraceae. Three, possibly five, species of Actinocyclus are restricted to the early middle Miocene; $A$. pinnulus is restricted to the late middle Miocene. Actinocyclus ehrenbergii Ralfs, a coastal marine species, has been found in latest Miocene to earliest Pliocene lake sediments, but because of its long geologic range in marine sediments and rarity in lacustrine rocks, it is probably not a useful biostratigraphic indicator in continental deposits. Fossil lacustrine Actinocyclus spp. are found elsewhere in the world and may have geologic ranges that differ in detail, but which are generally similar to those in the Western United States.
\end{abstract}

\section{INTRODUCTION}

Interest in lacustrine diatom biochronology has greatly increased in recent years (Servant-Vildary, 1978; Gasse, 1980; Rehakova, 1980; Bradbury and Krebs, 1982; Khursevich, 1982; Loginova, 1982; Loginova and others, 1984; Bradbury, 1984, 1986; Bradbury and others, 1985; VanLandingham, 1985; Fourtanier, 1987; Krebs and others, 1987; Theriot and Bradbury, 1987; Fourtanier and Gasse, 1988; Serieyssol, 1988). In the Western United States, lacustrine diatomaceous sediments are often interbedded with volcanic rock and are thus well suited for radiometric dating. Fossil microfloras can therefore be arranged geochronologically and key diatoms can be traced through time. In this manner, Krebs and others (1987) have documented the succession of several lacustrine diatom genera through the Neogene and Quaternary of the Western

\footnotetext{
${ }^{1}$ William N. Krebs, Amoco Production Co., 501 Westlake Park Blvd., Houston, Texas 77079

2J. Platt Bradbury, U.S. Geological Survey, MS 919 Box 25046, Denver Federal Center, Lakewood, Colorado 80225
}

United States (fig. 1). The purpose of this study is to present the geologic ranges of species belonging to one of these genera, Actinocyclus. These ranges will, of course, change as additional data accumulate and as lacustrine diatomaceous sediments become better dated. We present this information as our knowledge to date and hope that it will stimulate comparative studies in the Western United States and in other regions worldwide.

\section{MATERIALS AND METHODS}

Our data are derived from 115 localities in the Western United States, including Alaska, mostly from the Great Basin (fig. 2 and "Appendix"). From these localities, several hundred samples were collected and analyzed for their lacustrine diatom content. Forty-nine of these sites have radiometric dates or have age estimates based on stratigraphic relationships with other dated units. Of these 49 dated localities, 28 have obligate lacustrine species of Actinocyclusthat is, they are found only in continental (lake) deposits and only in association with other nonmarine diatom taxa (see chapter A). Unfortunately, the exact stratigraphic and depositional relationships of diatomaceous samples to the dated volcanic rock(s) are often obscure or poorly documented. In addition, radiometric dates may be inaccurate and conflicting. We are confident, however, that the general pattern of lacustrine diatom biochronology in the Western United States presented in figure 1 is accurate and that the species ranges of Actinocyclus (fig. 3) reflect evolutionary and (or) environmental changes during the Miocene.

Natural reworking and the rare occurrence of whole specimens or fragments poses problems of interpretation (Krebs and others, 1987). Excluding contamination during collecting and processing, rare occurrences of poorly preserved specimens older than the oldest known occurrence are regarded as significant and merit range extension. Rare (occasionally common) occurrences and fragments younger than the youngest true occurrence may be the result of natural reworking. Clearly, large upward range extensions based on rare occurrences evoke suspicion. Also, poor preservation (abrasion and (or) corrosion) of frustules relative to those of 


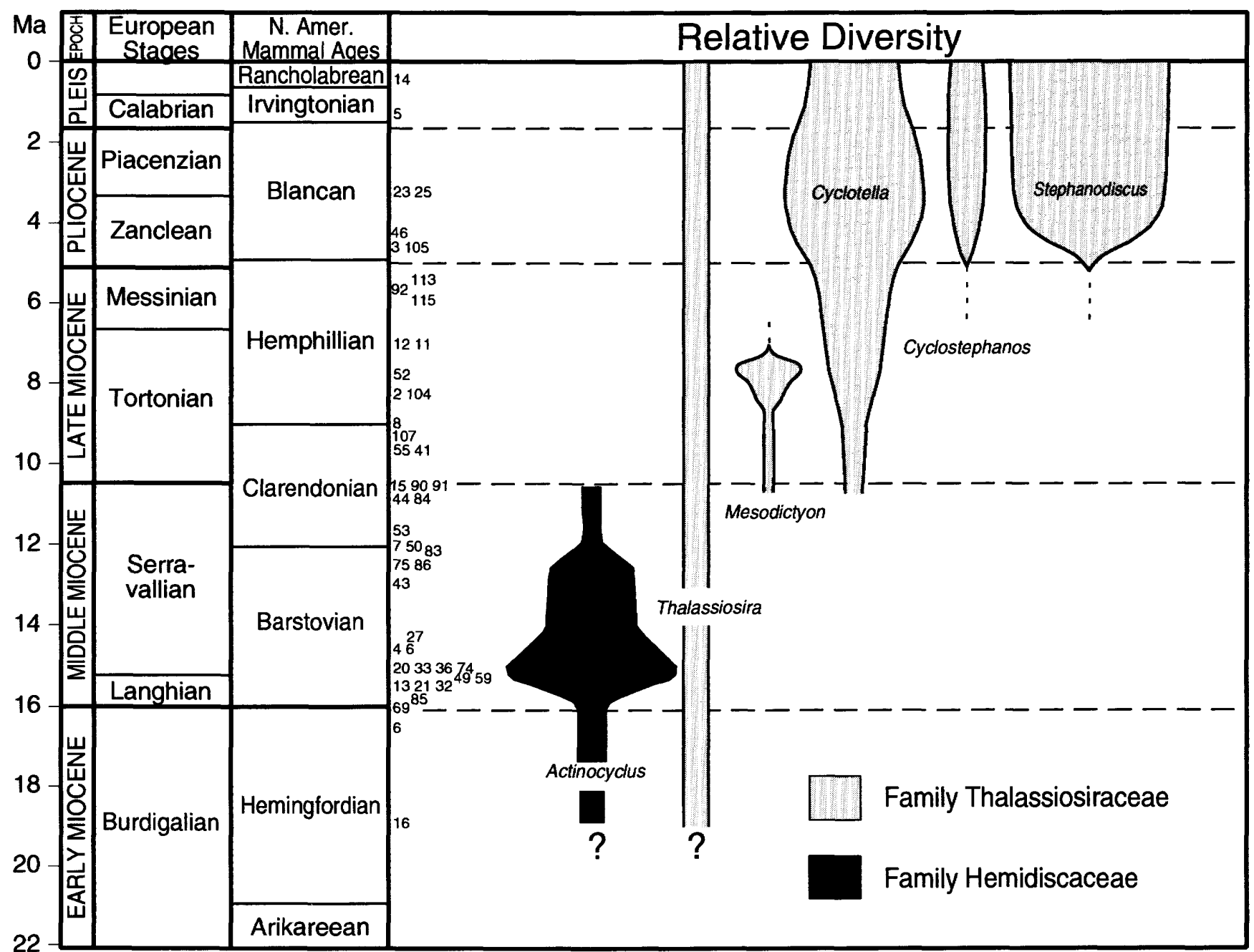

Figure 1. Biochronology and general relative diversities of six lacustrine diatom genera. Western United States. The numbers represent localities with radiometric ages (see "Appendix" and fig. 2). Diversity patterns are qualitative and not comparable between genera. Time scale is from Berggren and others (1985) and Haq and others (1987).

other diatoms in a sample may indicate reworking. In any case, we have queried occurrences and dashed lines where there is sufficient doubt about absolute age and (or) rare occurrences. Additional localities and closer examination of questionable occurrences may resolve these uncertainties.

\section{RESULTS}

The geologic ranges of lacustrine Actinocyclus species will be discussed in alphabetical order rather than by oldest first occurrence, which may change with additional information. Figure 3 is a range chart of these species.

\section{Actinocyclus acanthus Bradbury \& Krebs}

Actinocyclus acanthus was originally described as Cestodiscus apiculatus by Lohman (1957) from the Esmeralda
Formation (Miocene) at Cedar Mountain, Nye County, Nevada (loc. 74). Evernden and others (1964) obtained two radiometric dates from this formation in the Cedar Mountain area whose corrected average is $11.4 \mathrm{Ma}$. These two dates were taken $61 \mathrm{~m}$ and $76 \mathrm{~m}$, respectively, above early Clarendonian ( $\cong 12 \mathrm{Ma}$ ) vertebrates. J. H. Stewart (oral commun., 1988), however, reported that the lower (diatomaceous) half of the Esmeralda Formation dates from about 14 to $12 \mathrm{Ma}$ (Barstovian). Furthermore, recent field work in this area has demonstrated that there is an unconformity between the lower half of the "Esmeralda Formation" and the upper-half that yielded Clarendonian vertebrates and the dates of Evernden and others (1964) (H. E. Schorn, oral commun., 1989). Barstovian vertebrates have been found in the lower diatomaceous portion beneath the unconformity, and a radiometric date of 15.1 Ma obtained from this unit nearby (loc. 20) confirms this age. We, therefore, assign a Barstovian age to the diatomites collected by Lohman at Cedar Mountain 


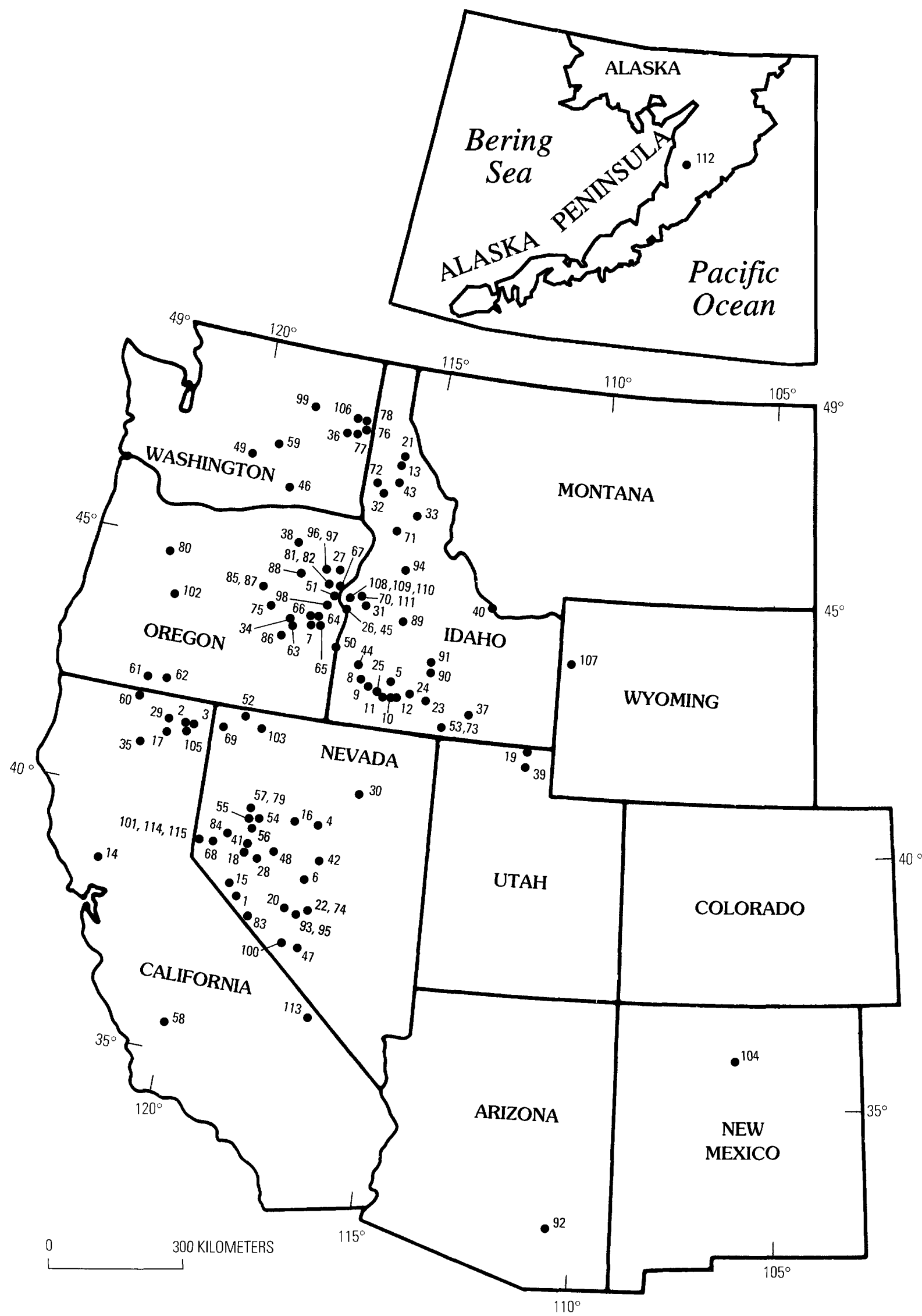

Figure 2. Location of sample sites (see "Appendix"). 


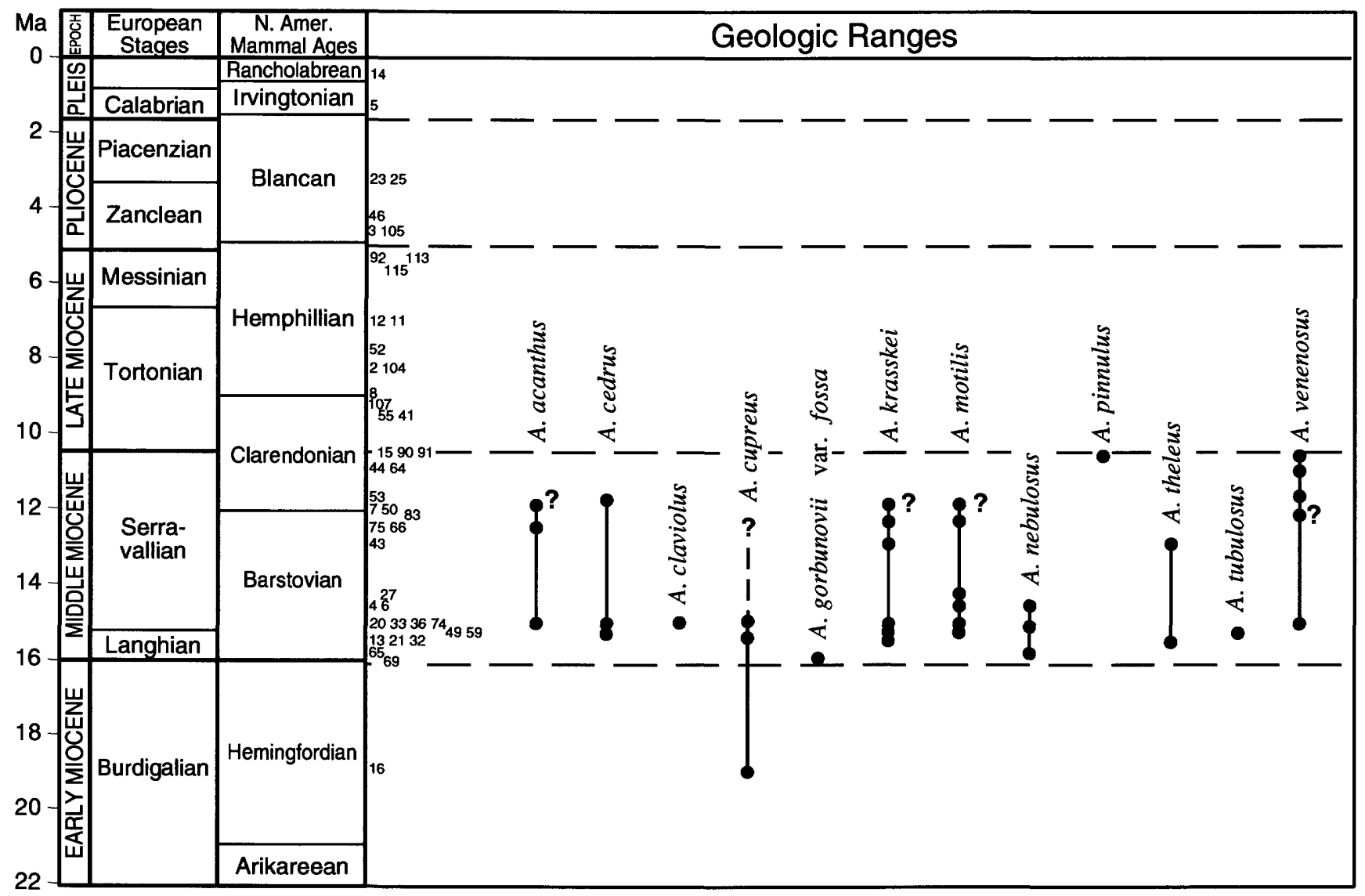

Figure 3. Preliminary range chart of obligate lacustrine Actinocyclus species, Western United States. The numbers represent localities with radiometric ages (see "Appendix" and fig. 2). The species ranges have been established by localities with radiometric ages.

(loc. 74), and estimate their absolute age at about 15.1 Ma. We do not know if $A$. acanthus occurs above the unconformity in this section.

The only other occurrences of $A$. acanthus are at the type locality, New Pass, Lander County, Nevada (loc. 42; undated), in Silvies Valley, Grant County, Oregon (loc. 75; about $12.5 \mathrm{Ma}$ ), possibly in the Latah Formation (Miocene) near Mead, Spokane County, Washington (loc. 106), and in the Bully Creek Formation (Miocene), Malheur County, Oregon (loc. 7), which has an estimated age of $12 \mathrm{Ma}$ (S.L. VanLandingham, written commun., 1983). This estimate appears loosely constrained, so the Bully Creek Formation may in fact be considerably older. Actinocyclus acanthus occurs in the lower middle Miocene (15.1 Ma) and may range into the mid middle Miocene (about $12 \mathrm{Ma}$ ).

\section{Actinocyclus cedrus Bradbury \& Krebs}

Lohman (1957) originally described this species as Cestodiscus cedarensis from the Esmeralda Formation at Cedar Mountain, Nye County, Nevada (loc. 74, about $15.1 \mathrm{Ma}$ ). Actinocyclus cedrus is common in many Miocene lacustrine formations of the Great Basin and can constitute nearly the entire mass of a diatomite, for example, in the southern Stillwater Mountains, Churchill County, Nevada (loc. 48). Among our sample localities, its oldest first occurrence is at the type locality at Diatomite Ridge, Stewart Valley, Mineral County, Nevada (loc. 20; $15.1 \mathrm{Ma})$. VanLandingham (1988), however, reported the presence of this species at New Pass Summit, Nevada (E $1 / 2$ sec. 32, T. 20 N., R. 40 E., Churchill County) in rocks that date from about $22 \mathrm{Ma}$ (Hudson and Geissman, 1988). Inasmuch as VanLandingham did not figure this species and was unclear how his sample relates stratigraphically to the dated tuff, we cannot confirm his assertion.

In addition to the above mentioned localities, $A$. cedrus has been found in the Squaw Creek Member of the Ellensburg Formation, Yakima County, Washington (loc. 49; 15.5-14.5 Ma), the Ellensburg Formation at Vantage, Grant County, Washington (loc. 59; 15.5-14.5 Ma), in the Beaverdam Formation at Trapper Creek, Cassia County, Idaho (loc. 53, estimated 12.0-11.5 Ma), in the Virginia Range north of Virginia City, Storey County, Nevada (loc. 68; undated), at Drewsey, Harney County, Oregon (loc. 63; undated), Turner Creek, Modoc County, California (loc. 17; late Barstovian-Clarendonian), Otis Creek, Harney County, 
Oregon (loc. 34; undated), Esmeralda Formation, Black Spring, Nye County, Nevada (loc. 93; undated) and in the Milford Federal No. 1 Well, Lemhi County, Idaho (loc. 40; undated). In the middle member of the Truckee Formation (Miocene) at Browns Hill, Churchill County, Nevada (loc. 55; $9.8 \mathrm{Ma}$ ), fragments and a few whole specimens of A. cedrus have been noted. Redeposited $A$. cedrus occurs in the middle member of the Truckee Formation near Fernley, Churchill County, Nevada (loc. $41 ; 9.8 \mathrm{Ma}$ ), and in the basal Truckee Formation in the Hot Springs Mountains, Churchill County, Nevada (loc. 56). It has also been reworked into the diatomite of the Kate Peak Formation at the Eagle-Picher diatomite quarry near Clark Siding, Storey County, Nevada (loc. 84; 11.2 $\pm 0.3 \mathrm{Ma}$ ). Deposits with abundant $A$. cedrus have been found to the southeast (for example, loc. 48) and southwest (for example, loc. 68) of Browns Hill (loc. 55). Therefore, we consider the occurrence at Browns Hill as possible reworked contamination. Actinocyclus cedrus, thus, has a known geologic range from 15 to about $12 \mathrm{Ma}$ (middle Miocene) in the Western United States, and it also occurs in Miocene lacustrine diatomite of the Moon-To Basin near Kunming in southwestern China.

\section{Actinocyclus claviolus Bradbury \& Krebs}

Actinocyclus claviolus has only been found at its type locality at Jungle Point, Idaho County, Idaho (loc. 33, 15.4-14.5 Ma). A few specimens and fragments occur in the Latah Formation (Miocene) near Mead, Spokane County, Washington (loc. 106; undated). Thus far, it is restricted to the lower middle Miocene.

\section{Actinocyclus cupreus Bradbury \& Krebs}

This species has been found at only four localities in the Western United States-the type locality at Copper Kettle Canyon, Churchill County, Nevada (loc. 16; 18.9 $1.2 \mathrm{Ma}$ ), at Juliaetta, Nez Perce County, Idaho (loc. 32; $15.3 \mathrm{Ma}$ ), at Jungle Point, Idaho County, Idaho (loc. 33, 15.4-14.5 Ma), and in the Humboldt Formation, Eureka County, Nevada (loc. 30; undated). Fields (1983) assigned a middle Miocene age to the Humboldt Formation. In the United States, $A$. cupreus ranges from the lower to middle Miocene $\geq 19$ to $\leq 15.3 \mathrm{Ma}$ ). A similar species of Actinocyclus has been found in lower Miocene freshwater deposits beneath the Sea of Japan and on the Japanese mainland (Koizumi, 1988).

\section{Actinocyclus gorbunovii var. fossa Bradbury \& Krebs}

We have found this taxon only at Forty-nine Camp, Washoe County, Nevada (loc. 69; $16 \mathrm{Ma}$ ). In the Western United States, its geologic age is approximately 16 $\mathrm{Ma}$ - earliest middle Miocene.

\section{Actinocyclus krasskei (Krasske) Bradbury \& Krebs}

Actinocyclus krasskei appears to be restricted to the lower middle and mid middle Miocene (15.3 to 12.5 or 12 Ma), although VanLandingham (1988) reported it from New Pass Summit, Nevada (about $22 \mathrm{Ma}$ ). As previously noted with Actinocyclus cedrus, we cannot confirm this occurrence.

Although small and variable in form, $A$. krasskei occurs abundantly, particularly in the lower middle Miocene of Idaho. Its youngest occurrence may be in the Bully Creek Formation, Malheur County, Oregon (loc. 7; estimated at 12 $\mathrm{Ma}$ ). The absolute age of this formation, however, is very uncertain and may well prove to be older. In addition, we have found $A$. krasske $i$ at the following localities: Juliaetta, Nez Perce County, Idaho (loc. 32; 15.3 Ma), Latah(?) Formation, Hangman Valley, Spokane County, Washington (loc. 36; 14.9 Ma), Squaw Creek Member, Ellensburg Formation, Yakima County, Washington (loc. 49; 15.5-14.5 Ma), Oviatt Creek, Clearwater County, Idaho (loc. 43; 12.8 Ma), Arrow Junction, Nez Perce County, Idaho (loc. 72; undated), near Weiser, Washington County, and Whitebird, Idaho County, Idaho (locs. 70, 71, respectively; undated), North Fork Fitsum Creek, Valley County, Idaho (loc. 94; undated), Silvies Valley, Grant County, Oregon (loc. 75; about $12.5 \mathrm{Ma}$ ), the Columbia River Basalt Group (Miocene), Seven Mile Creek, Umatilla County, Oregon (loc. 38; undated), in the Humboldt Formation, Eureka County, Nevada (loc. 30; undated), and in the Mascall Formation (Miocene) at Vinegar Creek, Grant County, Oregon (loc. 88; undated). In the Latah Formation, Spokane County, Oregon (locs. 76, 106; undated), rare (reworked?) Actinocyclus, possibly $A$. krasskei, has been observed.

\section{Actinocyclus motilis Bradbury \& Krebs}

Lohman (1957) first described this species as Cestodiscus mobilis (mobilensis) in his unpublished dissertation, and reported it from the Esmeralda Formation at Cedar Mountain, Nye County, Nevada (loc. 74; about $15.1 \mathrm{Ma}$ ). Actinocyclus motilis is widely distributed and often abundant in the Western United States. The type specimens come from locality 22 (Esmeralda Formation, Cedar Mountain, Mineral County, Nevada). This species also occurs in the Squaw Creek Member, Ellensburg Formation, Yakima County, Washington (loc. 49; 15.5-14.5 Ma), at Vantage, Grant County, Washington in the Ellensburg Formation (loc. 59; 15.5-14.5 Ma), Augusta Mountains, Churchill County, Nevada (loc. 4; 14.6 Ma), in the Juntura(?) Formation, Harney County, Oregon (loc. 86; 12.4 Ma), in the Bully Creek Formation, Harper Basin, Malheur County, Oregon (loc. 7; estimated $12 \mathrm{Ma}$ ), in the Esmeralda Formation, Black Spring, Nye County, Nevada (loc. 93; undated), in the Mascall Formation, White Hills, Grant County, Oregon (loc. 87; undated), and at Goose Creek, Baker County, Oregon 
(loc. 27; 14.5 Ma). These dated localities indicate a geologic range for A. motilis of about $15 \mathrm{Ma}$ to possibly $12 \mathrm{Ma}$ (middle Miocene) within the Western United States.

\section{Actinocyclus nebulosus Bradbury And Krebs}

Actinocyclus nebulosus, although very distinctive and locally abundant, has been found at only a few localities. Lohman (1957) originally described it in his unpublished dissertation as Cestodiscus fasciculatus from the Esmeralda Formation of Cedar Mountain, Nye County, Nevada (loc. 74; about 15.1 Ma). Smedman (1969) named it Coscinodiscus nevadensis, and reported its occurrence at Buffalo Canyon, Churchill County, Nevada (loc. 6; 14.6 Ma). Actinocyclus nebulosus also occurs in the Mascall Formation at Aldrich Mountain, Grant County, Oregon (loc. 85; about $15.8 \mathrm{Ma}$ ), in the Latah Formation near Mead, Spokane County, Washington (loc. 106), and in the Esmeralda Formation at Black Spring (loc. 93) and Cedar Spring (loc. 95), Nye County, Nevada. It is thus far restricted to the lower middle Miocene (15.8-14.6 Ma).

\section{Actinocyclus pinnulus Bradbury \& Krebs}

The type locality for A. pinnulus is the Hole-in-theWall diatomite (locs. 90, 91; 10.3 Ma) in Gooding County, Idaho, where it occurs in association with Mesodictyon Theriot \& Bradbury. It is also found with Mesodictyon at Durkee, Baker County, Oregon (loc. 81; undated). A form of Actinocyclus very similar to $A$. pinnulus is present near $-985 \mathrm{~m}$ in the AMOCO Becharof No. 1 well, Alaska (loc. 112) in deposits of unknown age. A. pinnulus is thus far restricted to the uppermost middle Miocene.

\section{Actinocyclus theleus Bradbury \& Krebs}

Actinocyclus theleus has been found at only a few sites in the Pacific Northwest: Emerald Creek, Benewah County (loc. 21; $15.3 \mathrm{Ma}$ ), Juliaetta, Nez Perce County (loc. 32; $15.3 \mathrm{Ma}$ ), Oviatt Creek, Clearwater County (loc. 43; 12.8 $\mathrm{Ma})$, Idaho, in the Mascall Formation, White Hills, Grant County, Oregon (loc. 87), and possibly reworked in the Latah Formation, Spokane County, Washington (locs. 76, 106). Its known range is, therefore, from the lower middle to mid middle Miocene (15.3-12.8 Ma).

\section{Actinocyclus tubulosus Khursevich}

Galina Khursevich (written commun., 1992) has confirmed the presence of Actinocyclus tubulosus in the Squaw Creek Member of the Ellensburg Formation, Yakima County, Washington (loc. 49, 15 Ma). It has not been found elsewhere in the United States and is thus far restricted to the early middle Miocene. Its similarity to and possible misidentification with Actinocyclus krasskei may partly account for its restricted range.

\section{Actinocyclus venenosus Bradbury \& Krebs}

Actinocyclus venenosus is found abundantly and well preserved at the type locality (loc. 44, Poison Creek Formation, Reynolds Creek, Owyhee County, Idaho, 8.9 Ma). This radiometric date is from the Banbury(?) basalt stratigraphically well above the last occurrence of $A$. venenosus in that section, and probably represents the uppermost age limit of the Poison Creek Formation. Armstrong and others (1975) reported that the formation is Clarendonian in age and estimated its age at $11 \mathrm{Ma}$ from dates on enclosing volcanic rocks. Fields (1983), after a thorough literature review, also centered the formation at $11 \mathrm{Ma}$. For the purposes of this study, we accept this estimate as the most accurate.

Actinocyclus venenosus also occurs in the Esmeralda Formation, Cedar Mountain, Nye County, Nevada (loc. 74; about $15.1 \mathrm{Ma}$ ), the Coal Valley Formation, Pine Grove Hills, Lyon County, Nevada (loc. 15, 11.1-9.5 Ma), the Beaverdam Formation at Trapper Creek, Cassia County, Idaho (loc. 53, estimated 12.0-11.5 Ma), an unnamed unit at Turner Creek, Modoc County, California (loc. 17), and at sites within the Poison Creek Formation (locs. 108, 109) and Idaho Group (locs. 31, 111), Washington County, Idaho. Poorly preserved, possibly reworked specimens of A. venenosus (?) have been observed within the Sucker Creek Formation (Miocene) at Leslie Gulch, Malheur County, Oregon (loc. 50; estimated $12 \mathrm{Ma}$ ). Its geologic range in the United States appears to span most of the middle Miocene (15 to about $11 \mathrm{Ma}$ ). Actinocyclus aff. $A$. venenosus has been found in Miocene lacustrine diatomites of the Xian Feng Basin of southwest China (Bradbury, 1984; chapter A).

\section{DISCUSSION}

In the Western United States, obligate freshwater species of Actinocyclus range from the lower Miocene to upper middle Miocene (about 19 to $10 \mathrm{Ma}$ ). We have examined Oligocene and lowest Miocene lacustrine diatomaceous sediments from southwestern Montana, Eocene material from British Columbia, Idaho, and Montana, and Oligocene material from Colorado and Nevada, but we have not found Actinocyclus. An upper Eocene diatom assemblage from Wyoming does not contain Actinocyclus (Lohman and Andrews, 1968). Similarly, our extensive collection of upper Miocene and younger material has failed to produce fossil obligate lacustrine Actinocyclus species that are not probable contaminants reworked from older sediments. We have confirmed however, the presence of $A$. ehrenbergii in lacustrine sediments of the Quiburis Formation at Edgar Canyon near Tucson, Pima County, Arizona (loc. 92) and in the Furnace 
Creek Formation of Death Valley, Inyo County, California (loc. 113). The Quiburis Formation is latest Miocene in age (6.6-5.4 Ma; Shenk, 1990) and apparently formed in a moderately saline (sodium chloride) lake. The age of the Furnace Creek Formation (7.35-5.18 Ma) (Marvin and Dobson, 1979) is late Miocene to earliest Pliocene. Actinocyclus ehrenbergii is a coastal marine species that can live in lagoons and saline lakes (Yezdani, 1970; Foged, 1978). Although of ecological interest, it is probably not biostratigraphically important because (1) its age range in marine rocks extends from at least the early Oligocene (Fenner, 1977 ) to the Holocene, and (2) it is rare in lacustrine diatomaceous sediments.

Elsewhere in the world, freshwater species of Actinocyclus appear to have a longer geologic range. In the former Soviet Union, for example, the genus may range from the early Miocene, or even the late Oligocene (Moisseeva and others, 1974), to early Pliocene, although its maximum diversity occurred during the middle Miocene (Khursevich, 1982). Similarly, Actinocyclus occurs in early Pliocene deposits in Bulgaria (Temniskova-Toplova and OgnjanovaRumenova, 1990). Although these reported ranges are without radiometric age control, the associations of diatom genera within samples do indicate significant differences in the geologic ranges of some lacustrine diatom genera between western North America and Eurasia. Late Miocene samples from Macedonia in northern Greece (Gersonde and Velitzelos, 1977) confirms this conclusion. In these samples, Stephanodiscus Ehrenberg and obligate freshwater Actinocyclus are common and co-occur, an association never seen in the Western United States except for isolated (probably contaminated) examples (for examples, see VanLandingham, 1964, 1967). Nevertheless, Fourtanier (1987) and Serieyssol (1988) have demonstrated that there is a remarkable synchroneity of events in the evolution of lacustrine diatoms between continents-that is, the decline of Actinocyclus during the late Miocene, the late Miocene species diversification of Mesodictyon Theriot and Bradbury, and the appearance of Stephanodiscus and Cyclostephanos Round near the Miocene-Pliocene boundary.

In conclusion, we note that the appearance of freshwater Actinocyclus in the Western United States coincides with the early Miocene species radiation of marine Actinocyclus (Radionova, 1987), high stand in sea level (Haq and others, 1987), and the initiation of extensional basin-and-range tectonics (Stewart and Carlson, 1976). Furthermore, the worldwide decline in freshwater Actinocyclus during the late Miocene corresponds with the origin and (or) species radiations of Mesodictyon and Cyclotella (Kützing) Brebisson, and the appearance of Stephanodiscus and Cyclostephanos. The ways in which paleoenvironmental changes and species competition influenced the course of lacustrine diatom evolution remain unknown but are worthy of study.

\section{REFERENCES}

Armstrong, R.L., Leeman, W.P., and Malde, H.E., 1975, K-Ar dating, Quaternary and Neogene volcanic rocks of the Snake River Plain, Idaho: American Journal of Science, v. 275(3), p. 225-251.

Axelrod, D.I., 1958, The Pliocene Verdi flora of western Nevada: University of California Publications in the Geological Sciences, v. 34, p. 91-159.

-1966, Potassium-argon ages of some western Tertiary floras: American Journal of Science, v. 264, no. 7, p. 497-506.

Beeson, M.H., Fecht, K.R., Reidel, S.P., and Toland, T.L., 1985, Regional correlations within the Frenchman Springs Member of the Columbia River Basalt Group: new insight into the middle Miocene tectonics of northwestern Oregon: Oregon Geology, v. 47, p. 87-96.

Berggren, W.A., Kent, D.V., Flynn, J.J., and Van Couvering, J.A., 1985, Cenozoic geochronology: Geological Society of America Bulletin, v. 96, p. 1407-1418.

Bradbury, J.P., 1984, Fossil Actinocyclus species from freshwater Miocene deposits in China and the United States: in Mann, D.G. (ed.), Proceedings of the 7th International Diatom Symposium, Philadelphia, 22-27 August, 1982: Koenigstein, Germany, Koeltz, p. 157-171.

-1986, Continental diatom biostratigraphy and paleolimnology: a review and evaluation of research directions and applications: in Ricard, Michel (ed.), Proceedings 8th International Diatoms Symposium, Paris: Koenigstein, Germany, Koeltz, p. 667-686.

Bradbury, J.P., Dieterich, K.V., and Williams, J.L., 1985, Diatom flora of the Miocene lake beds near Clarkia in northern Idaho: in Smiley, C. J. (ed.), Late Cenozoic history of the Pacific Northwest: San Francisco, California, Pacific Division of the American Association for the Advancement of Science, p. 33-59.

Bradbury, J.P., and Krebs, W.N., 1982, Neogene and Quaternary lacustrine diatoms of the western Snake River Basin, IdahoOregon, USA: Acta Geologica Academiae Scientiarum Hungaricae, v. 25, no. 1-2, p. 97-122.

Dalrymple, G.B., 1979, Critical tables for conversion of $\mathrm{K}$-Ar ages from old to new constants: Geology, v. 7, p. 558-560.

Evernden, J.F., and James, G.T., 1964, Potassium-argon dates and the Tertiary floras of North America: American Journal of Science, v. 262, p. 945-974.

Evernden, J.F., Savage, D.E., Curtis, G.H., and James, G.T., 1964, Potassium-argon dates and the Cenozoic mammalian chronology of North America: American Journal of Science, v. 262, p. 145-198.

Fenner, Juliane, 1977, Cenozoic diatom biostratigraphy of the equatorial and southern Atlantic Ocean: in Supko, P. R., and others (eds), Initial Reports of the Deep Sea Drilling Project: National Science Foundation, v. 39, p. 491-624.

Fiebelkorn, R.B., Walker, G.W., MacLeod, N.S., McKee, G.H., and Smith, J.G., 1983, Index to K-Ar determinations for the state of Oregon: Isochron/West, v. 37, p. 3-60.

Fields, P.F., 1983, A review of the Miocene stratigraphy of southwestern Idaho, with emphasis on the Payette Formation and associated floras: Berkeley, University of California, M.S. Thesis, $363 \mathrm{p}$. 
Foged, Niels, 1978, Diatoms in eastern Australia: Bibliotheca Phycologia, v. 41, 242 p.

Fourtanier, Elisabeth, 1987, Diatomées Néogènes d'Afrique: Approche biostratigraphique en milieux marin (sud-ouest africain) et continental: Paris, Thèse de Doctorat de l'Universite P. et M. Curie, Mémoires des Sciences de la Terre, Université Paris, no. 87-44, 365 pp.

Fourtanier, Elisabeth, and Gasse, Françoise, 1988, Premiers jalons d'une biostratigraphie et évolution des diatomées lacustres d'Afrique depuis $11 \mathrm{Ma}$ : Comptes Rendus de l'Académie des Sciences de Paris, 306, séries II, p. 1401-1408.

Gasse, Françoise, 1980, Les diatomées lacustres plio-pléistocènes du Gadeb (Ethiopie): systématique, paléoécologie, biostratigraphie: Revue Algologique, v. 3 p. 1-249.

Gersonde, Rainer, and Velitzelos, Evagelos, 1977, Diatomeenpaläoökologie im Neogen-Becken von Vegora N-W Mazedonien (Vorläufige Mitteilung): Annales Géologiques des Pays Helléniques, v. 29, p. 373-382.

Gilbert, C.M., and Reynolds, M.W., 1973, Character and chronology of basin development, western margin of the Basin and Range province: Geological Society of America Bulletin, v. 84, no. 8, p. 2489-2510.

Golia, R.T., and Stewart, J.H., 1984, Depositional environments and paleogeography of the Upper Miocene Wassuk Group, west-central Nevada: Sedimentary Geology, v. 38, p. 159-180.

Haq, B.U., Hardenbol, Jan, and Vail, P.R., 1987, Chronology of fluctuating sea levels since the Triassic: Science, v. 235 , no. 4793, p. 1156-1167.

Hudson, M.R., and Geissman, J.W., 1988, Reply on "Paleomagnetic and structural evidence for middle Tertiary counterclockwise block rotation in the Dixie Valley region, westcentral Nevada": Geology, v. 16, no. 8, p. 757.

Khursevich, G.K., 1982, Neogene diatom assemblages from Byelorussia and their stratigraphic significance: Acta Geologica Academiae Scientiarum Hungaricae, v. 25, nos. 1-2, p. 123-134.

Kimmel, P.G., 1979, Stratigraphy and paleoenvironments of the Miocene Chalk Hills Formation and Pliocene Glenns Ferry Formation in the western Snake River Plain, Idaho: Ann Arbor, University of Michigan, Ph.D. dissertation, $331 \mathrm{p}$.

Koizumi, Itaru, 1988, Early Miocene Proto-Japan sea: Journal of the Paleontological Society of Korea, v. 4, p. 6-20.

Krebs, W.N., Bradbury, J.P., and Theriot, E.C., 1987, Neogene and Quaternary lacustrine diatom biochronology, Western USA: Palaios, v. 2, p. 505-513.

Loginova, L.P., 1982, The Likhvin diatom flora from the central part of the East European Plain, its paleogeographical and stratigraphical significance: Acta Geologica Academiae Scientiarum Hungaricae, v. 25, nos. 1-2, p. 149-160.

Loginova, L. P., Lupikina, E. G., and Khursevich, G. K., 1984, 0 novom predstavitele roda Cyclostephanos Round i ego stratigraficheskom znachenii: Dokladi Akademii Nauk BSSR, Botanika v. 28, no. 2, p. 170-173.

Lohman, K. E., 1957, Cenozoic non-marine diatoms from the Great Basin: Pasadena, California Institute of Technology, Ph.D. dissertation, $190 \mathrm{p}$.

Lohman, K.E., and Andrews, G.W., 1968, Late Eocene nonmarine diatoms from the Beaver Divide area, Fremont County, Wyoming: U.S. Geological Survey Professional Paper 593-E, 26 p.
Malde, H.E., 1972, Stratigraphy of the Glenns Ferry Formation from Hammett to Hagerman, Idaho: U.S. Geological Survey Bulletin 1331-D, 19 p.

Manley, Kim, and Mehnert, H.H., 1981, New K-Ar ages for Miocene and Pliocene volcanic rocks in the northwestern Española Basin and their relationships to the history of the Rio Grande Rift: Isochron/West, no. 30, p. 5-8.

Marvin, R.F., and Dobson, S.W., 1979, Radiometric ages: compilation B, U.S. GeologicaI Survey: Isochron/West, no. 26, p. 3-32.

Moisseeva, A.I., Rubina, N.V., Cheremisinova, E.A., 1974, Miocene diatoms (Chapter 11, Neogene freshwater diatom algae) in Gleser, S.I., Jouse, A.P., Marakova, I.V., ProschinkaLavrenko, A.I., and Sheshukova-Poretzkaja, V.S., (eds), Diatom algae of the USSR. vol. 1, NAUKA, Leningrad: Koenigstein, Germany, Koeltz, p. 190-204. [Reprint 1979]

Neville, Coleen, Opdyke, N.D., Lindsay, E.H., and Johnson, N.M., 1979, Magnetic stratigraphy of Pliocene deposits of the Glenns Ferry Formation, Idaho, and its implications for North American mammalian biostratigraphy: American Journal of Science, v. 279 , no. 5 , p. 503-526.

Radionova, E.P., 1987, Diatom morphology of the genus Cestodiscus from lower middle Miocene deposits of the tropical zone of the Pacific Ocean: Academy of Sciences, USSR, Institute of Geology, Micropaleontology Edition, Issue 29, p. 141-154.

Rehakova, Zadenka, 1980, Süsswasserdiatomeenflora des oberen Miozäns in der Tschechoslowakei: Journal of Geological Sciences, v. 23, p. 83-184.

Repenning, C.A., 1987, Biochronology of the microtine rodents of the United States: in Woodburne, M.O., (ed.), Cenozoic mammals of North America, Geochronology and Biostratigraphy: Berkeley, University of California Press, p. 236-268.

Rymer, M.J., 1981, Stratigraphic revision of the Cache Formation (Pliocene and Pleistocene), Lake County, California: U.S. Geological Survey Bulletin 1502-C, p. 1-35.

Serieyssol, K.K., 1988, Biostratigraphy and taxonomic interpretations based on the survey of fossil freshwater centric genera [abs]: Huhmari, Joensuu, Finland, 10th International Diatom Symposium, Aug. 28-Sept. 2, 1988, p. 114.

Servant-Vildary, Simone, 1978, Étude des diatomées et paléolimnologie du bassin Tchadien au Cénozoique superieur: Travaux et documents de ORSTOM, v. 84, 346 p. [2 volumes]

Shenk, J.D., 1990, Economic geology of the White Cliffs diatomite deposit, Mammoth, Arizona: Tucson, University of Arizona, M.S. Thesis, $156 \mathrm{p}$.

Smedman, Gunilla, 1969, An investigation of the diatoms from four Tertiary lake bed deposits in western Nevada: PaleoBios [Contributions from the University of California Museum of Paleontology, Berkeley] no. 9, 16 p.

Smiley, C.J., and Rember, W.C., 1985, Physical setting of the Miocene Clarkia fossil beds, northern Idaho: in Smiley, C.J., (ed.), Late Cenozoic history of the Pacific Northwest: San Francisco, California, Pacific Division of the American Association for the Advancement of Science, p. 11-31.

Smith, G.A., 1988, Neogene synvolcanic and syntectonic sedimentation in central Washington: Geological Society of America Bulletin, v. 100, p. 1479-1492.

Stewart, J.H., and Carlson, J.E., 1976, Cenozoic rocks of Nevada-Four maps and brief description of distribution, 
lithology, age, and centers of volcanism: Nevada Bureau of Mines and Geology, Map 52, p. 1-5.

Temniskova-Topalova, Dobrinka, and Ognjanova-Rumenova, Nadja, 1990, Non-marine diatoms from Neogene sediments of Bulgaria: in Simola, Heikki, (ed.), Proceedings, 10th International Diatom Symposium, Joensuu, Finland (1988): Koenigstein, Germany, Koeltz, p. 357-363.

Theriot, E.C., and Bradbury, J.P., 1987, Mesodictyon, a new fossil genus of the centric diatom family Thalassiosiraceae from the Miocene Chalk Hills Formation, western Snake River Plain, Idaho: Micropaleontology, v. 33, no. 4, p. 356-367.

VanLandingham, S.L., 1964, Miocene non-marine diatoms from the Yakima region in south central Washington: Beihefte zur Nova Hedwigia, Heft 14, 78 p.

1967, Paleoecology and microfloristics of Miocene diatomites from the Otis Basin-Juntura region of Harney and Malheur Counties, Oregon: Beihefte zur Nova Hedwigia, Heft 26, $77 \mathrm{p}$.
-1985, Potential Neogene diagnostic diatoms from the western Snake River Basin, Idaho and Oregon: Micropaleontology, v. 31 , no. 2 , p. 167-174.

1988, Comment on "Paleomagnetic and structural evidence for middle Tertiary counterclockwise block rotation in the Dixie Valley region, west-central Nevada": Geology, v. 16 , no. 8 , p. 756 .

Wolfe, J.A., 1971, Tertiary climate fluctuations and methods of analysis of Tertiary floras: Palaeogeography, Palaeoclimatology, Palaeoecology, v. 9, no. 1, p. 27-59.

Wood, H.E., Chaney, R.W., Clarke, John, Colbert, E.H., Jepsen, G.L., Reeside, Jr., J.B., and Stock, Chester, 1941, Nomenclature and correlation of the North American continental Tertiary: Geological Society of America Bulletin, v. 52, p. 1-48.

Yezdani, G.H., 1970, A study of the Quaternary vegetation history in the volcanic lakes region of western Victoria: Clayton, Victoria, Australia, Monash University, Ph.D. dissertation, $522 \mathrm{p}$.

Published in the Central Region

Manuscript approved for publication July 19, 1993

Graphics by J. Platt Bradbury and William N. Krebs

Edited by Thomas Kohnen

Photocomposition by Marie Melone 


\section{APPENDIX}

List of Diatom Sample Localities 


\section{LIST OF DIATOM SAMPLE LOCALITIES}

Localities with absolute ages are marked with an asterisk (*); + identifies localities with Actinocyclus. The location of each sample site is shown in figure 2 . Locality information includes the name of the formation (if known), geographic coordinates, the name of the collector and sampling year, and age (if known), and where the information has been published. Radiometric ages have been corrected according to Dalrymple (1979). Formation names in quotes indicate that the assigned name is of dubious validity. (?) indicates that the deposit is not assignable to the formation with certainty. "UCMP" = University of California Museum of Paleontology; "P\#\#\#" = plant locality number.

1+ Aldrich Station(?) Formation, east Walker River, $38.84^{\circ}$ N., $119.06^{\circ}$ W., Lyon Co., Nevada, J. H. Stewart, 1980; Miocene.

2* Alturas Formation, Howards Gulch, sec. 27, T. 42 N., R. 15 E., Modoc Co., California, R. A. Laws, 1981; 8.1 Ma (Evernden and James, 1964), 8.3 Ma corrected.

3* Alturas Formation, 3.5 miles west of Alturas, California Academy of Sciences locality 36805, Modoc Co., California, G. D. Hanna; 4.8 Ma (Repenning, 1987).

4*+ Augusta Mountains, unnamed unit, sec. 31, T. 24 N., R. 39 E., Churchill Co., Nevada, W. N. Krebs, 1982; 14.6 Ma (Krebs and others, 1987).

5* Bruneau Formation, W. Snake River Plain, sec. 27, T. 5 S., R. 4 E., Elmore Co., Idaho, J. P. Bradbury, 1978; 1.36 Ma (Evernden and others, 1964), 1.4 Ma (Armstrong and others, 1975).

$6^{*}+$ Buffalo Canyon Formation, Buffalo Canyon, sec. 2, T. 15 N., R. 37 E., southeast of Eastgate, Churchill Co., Nevada, D. I. Axelrod, (Smedman, 1969); 14.6 \pm 0.4 Ma (AMOCO, unpublished data, 1982), 14.5-15.0 Ma (H. E. Schorn, written commun., 1989).

$7^{*}+$ Bully Creek Formation, type section, Harper Basin, sec. 11, T. 19 S., R. 41 E., Malheur Co., Oregon, W. N. Krebs, 1980; middle Miocene (estimated 12 Ma) VanLandingham, written commun., 1983).

8* Chalk Hills Formation, base of formation, West Browns Creek, sec. 2, T. 5 S., R. 1 W., Owyhee Co., Idaho, W. N. Krebs, 1980; about 9 Ma (Kimmel, 1979).

9* Chalk Hills Formation, Castle Creek, sec. 9, T. 6 S., R. 1 E., Owyhee Co., Idaho, W. N. Krebs, 1980; 7-9 Ma (Kimmel, 1979).

10* Chalk Hills Formation, Chalk Hills, sec. 20, T. 7 S., R. 4 E., Owyhee Co., Idaho, W. N. Krebs, 1980; 7-9 Ma (Kimmel, 1979).
11* Chalk Hills Formation, Shoofly Creek, lower Horse Hill ash, sec. 9, T. 7 S., R. 3 E., Owyhee Co., Idaho, M. J. Evetts, 1979; 7 Ma (Kimmel, 1979).

12* Chalk Hills Formation, type section, lower Horse Hill ash, sec. 25, T. 7 S., R. 4 E., Owyhee Co., Idaho, M. J. Evetts, 1979; 7 Ma (Kimmel, 1979).

13*+Clarkia Basin, unnamed unit, sec. 13, T. 42 N., R. 1 E., Shoshone Co., Idaho, C. J. Smiley; 15.3 Ma (Bradbury and others, 1985).

14* Kelseyville Formation, Clear Lake, sec. 27, T. 13 N., R. 9 W., Lake Co., California, M. J. Rymer, 1978; 0.4 Ma (Rymer, 1981).

$15^{*}+$ Coal Valley Formation, Pine Grove Hills, sec. 2, T. 9 N., R. 26 E., Lyon Co., Nevada, J. H. Stewart, 1983; 9.3-10.8 Ma (Gilbert and Reynolds, 1973), 9.5-11.1 Ma corrected.

$16^{*}+$ Copper Kettle Canyon, unnamed unit, sec. 26, T. 24 N., R. 34 E., Churchill Co., Nevada, W. N. Krebs, 1982; 18.9 \pm 1.2 Ma (AMOCO, unpublished data, 1982).

17+ Turner Creek, unnamed unit, sec. 1, T. 41 N., R. 8 E., Modoc Co., California, J. P. Bradbury, 1985; late Barstovian-Clarendonian (J. A. Wolfe, oral commun., 1985).

18 Dead Camel Mountains, unnamed unit, sec. 24, T. 18 N., R. 26 E., Churchill Co., Nevada, W. N. Krebs, 1981; Miocene.

19 AMOCO Delta Stephan Szot No. 1 well, sec. 19, T. 14 N., R. 1 E., Cache Co., Utah, W. N. Krebs, 1983.

20*+Esmeralda Formation, Diatomite Ridge, Stewart Valley, $38^{\circ} 37^{\prime} 02^{\prime \prime}$ N., $117^{\circ} 56^{\prime} 35^{\prime \prime}$ W., Mineral Co., Nevada, S. W. Starratt, 1986, 15.1 Ma (S. W. Starratt, written commun., 1986).

$21 *+$ Clarkia Basin, Emerald Creek, unnamed unit, sec. 33, T. 43 N., R. 1 E., Benewah Co., Idaho, C. J. Smiley, 1978; 15.3 Ma (Bradbury and others, 1985).

22+ Esmeralda Formation, Cedar Mountain, $38.5^{\circ} \mathrm{N}$., $44.75^{\circ}$ W., Mineral Co., Nevada, J. H. Stewart, 1980; Miocene.

23* Glenns Ferry Formation, Hagerman Horse quarry, sec. 16, T. 7 S., R. 13 E., Twin Falls Co., Idaho, J. P. Bradbury, 1979; about 3.2 Ma (Neville and others, 1979).

24 Glenns Ferry Formation, Malde's (1972) section no. 55 , sec. 1 , T. 6 S., R. 8 E., Owyhee Co., Idaho, M. J. Evetts, 1979; Pliocene.

25* Glenns Ferry Formation, Shoofly Creek, sec. 6, T. 7 S., R. 3 E., Owyhee Co., Idaho, M. J. Evetts, 1979; 3.0-3.3 Ma (M. L. Porter, oral commun., 1985).

26 Glenns Ferry (?) Formation, Weiser, sec. 35, T. 15 S., R. 46 E., Washington Co., Idaho, M. J. Evetts, 1979; Pliocene(?).

27*+Goose Creek, unnamed unit, sec. 29, T. 8 S., R. 43 E., Baker Co., Oregon, J. P. Bradbury, 1978, 14.5 Ma (Fiebelkorn and others, 1983). 
28 Michel T. Halbouty Federal No. 1 well, sec. 14, T. 17 N., R. 28 E., Churchill Co., Nevada, W. N. Krebs, 1982.

29 Alturas Formation, Howards Gulch, sec. 22, T. 42 N., R. 9 E., Modoc Co., California, J. P. Bradbury, 1985; Miocene.

30+ Humboldt Formation, sec. 31, T. 31 N., R. 52 E., Eureka Co., Nevada, Susan Laule, 1979; Miocene.

31+ IW-24, IW-26, Idaho Group, sec. 34, T. 12 N., R. 4 W., Washington Co., Idaho, M. J. Evetts, 1979; Neogene.

$32 *+$ Juliaetta, unnamed unit, sec. 20 , T. 37 N., R. 3 W., Nez Perce Co., Idaho, C. J. Smiley; 15.3 Ma (Bradbury and others, 1985).

33*+Jungle Point, unnamed unit, sec. 15, T. 33 N., R. 6 E., Idaho Co., Idaho; 14.5-15.4 Ma (Smiley and Rember, 1979).

34+ Juntura(?) Formation, Otis Creek, sec. 32, T. 19 S., R. 36 E., Harney Co., Oregon, J. P. Bradbury, 1978; Miocene.

35 Lake Britton, unnamed unit, sec. 29, T. 37 N., R. 3 E., Shasta Co., California, R. A. Laws, 1981.

36*+Latah(?) Formation, Hangman Valley, sec. 6, T. 24 N., R. 43 E., Spokane Co., Washington, J. P. Bradbury, 1979; 14.5 Ma (Evernden and James, 1964; 14.9 Ma corrected).

37 Raft River Formation, Burley, sec. 35, T. 10 S., R. 27 E., Cassia Co., Idaho, J. P. Bradbury, 1979; Pleistocene.

38+ Lower(?) part of the Columbia River Basalt Group, Seven Mile Creek, sec. 19, T. 2 S., R. 33 E., Umatilla Co., Oregon, M. J. Evetts, 1979; Miocene.

39 AMOCO Lynn Reese No. 1 well, sec. 17, T. 12 N., R. 1 E., Cache Co., Utah, W. N. Krebs, 1983.

40+ AMOCO Milford Federal No. 1 well, sec. 19, T. 15 N., R. 27 E., Lemhi Co., Idaho, W. N. Krebs, 1983.

$41^{*}+$ Truckee Formation (middle member), Fernley, sec. 8, T. 19 N., R. 26 E., Churchill Co., Nevada, W. N. Krebs, 1981; $9.8 \mathrm{Ma}$ (F. H. Brown, unpublished data, 1986).

42+ New Pass, unnamed unit, unsurveyed T. 19 N., R. 40 E., Lander Co., Nevada, J. P. Bradbury, 1985; Miocene.

43*+Oviatt Creek, unnamed unit, sec. 12, T. 39 N., R. 1 E., Clearwater Co., Idaho, C. J. Smiley; $12.8 \mathrm{Ma}$ (Smiley and Rember, 1979).

44*+Poison Creek Formation, Reynolds Creek, NW $1 / 4$ sec. 2, T. 2 S., R. 3 W., Owyhee Co., Idaho, W. N. Krebs, 1980; minimum age $8.9 \mathrm{Ma}$ (Krebs and others, 1987), estimated $11 \mathrm{Ma}$ (Armstrong and others, 1975).

45+ Poison Creek Formation, sec. 17, T. 11 N., R. 6 W., Washington Co., Idaho, M. J. Evetts, 1979; Miocene.
46* Ringold Formation, White Cliffs, Columbia River, sec. 1, T. 10 N., R. 28 E., Franklin Co., Washington, J. P. Bradbury, 1978; $4.3 \mathrm{Ma}$ (Repenning, 1987).

47 Big Smokey Valley, unnamed unit, unsurveyed T. 2 N., R. 38 E., Esmeralda Co., Nevada, J. P. Bradbury, 1984; Miocene.

48 + Southern Stillwater Mountains, unnamed unit, sec.22, T. 18 N., R. 31 E., Churchill Co., Nevada; Miocene. 49*+Squaw Creek Member, Ellensburg Formation, sec. 9, T. 14 N., R. 19 E., Yakima Co., Washington, J. P. Bradbury, 1979; 14.5-15.5 Ma (Beeson and others, 1985), 15 Ma (Smith, 1988).

50*+Sucker Creek Formation, Leslie Gulch, sec. 28, T. 24 S., R. 46 E., Malheur Co., Oregon, M. J. Evetts, 1979; estimated $12 \mathrm{Ma}$ (Fields, 1983).

51 Swayze Creek, unnamed unit, sec. 6, T. 12 S., R. 44 E., Baker Co., Oregon, J. P. Bradbury, 1978.

52* Thousand Creek Formation, unsurveyed T. 46 N., R. 25 E., Humboldt Co., Nevada, J. P. Bradbury, 1985; Hemphillian (Wood and others, 1941), estimated 7.8 Ma (VanLandingham, written commun., 1983).

53*+Beaverdam Formation, Trapper Creek, sec. 2, T. 15 S., R. 20 E., Cassia Co., Idaho, C. J. Smiley; estimated 11.5-12.0 Ma (Wolfe, 1971).

54+ Truckee Formation (middle member), Bradys Hot Spring, sec. 21, T. 23 N., R. 27 E., Churchill Co., Nevada, W. N. Krebs, 1981; Miocene.

$55^{*}+$ Truckee Formation (middle member), Browns Hill, sec. 33, T. 23 N., R. 27 E., Churchill Co., Nevada, W. N. Krebs, 1981;9.8 Ma (Krebs and others, 1987).

56+ Truckee Formation (lower member), Hot Springs Mountains, sec. 36, T. 22 N., R. 27 E., Churchill Co., Nevada, W. N. Krebs, 1981; Miocene.

57+ Truckee Formation (middle member), Nightingale, sec. 18, T. 24 N., R. 26 E., Churchill Co., Nevada, W. N. Krebs, 1981; Miocene.

58 Tulare Formation, La Ceja Ridge, Kettleman Hills, secs. 26 and 35, T. 21 S., R. 17 E., Kings Co., California; Pliocene to Pleistocene.

59*+Ellensburg Formation, Vantage, sec. 17, T. 18 N., R. 23 E., Grant Co., Washington, 14.5-15.5 Ma (Beeson and others, 1985).

60 "Yonna" Formation, Dorris, sec. 11, T. 47 N., R. 1 E., Siskiyou Co., California, J. P. Bradbury, 1978; Pliocene.

61 "Yonna" Formation, Klamath Falls, sec. 23, T. 38 S., R. 8 E., Klamath Co., Oregon, Maura O'Brian, 1980; Pliocene.

62 "Yonna" Formation, Yonna Valley, sec. 23, T. 38 S., R. 11 1/2 E., Klamath Co., Oregon, J. P. Bradbury, 1978; Pliocene.

63+ Unnamed unit, USGS 1019, 1020, Drewsey, sec. 14, T. 20 S., R. 36 E., Harney Co., Oregon, B. N. Moore, 1931. 
64+ Bully Creek Formation, USGS 1022, Westfall, Harper Basin, sec. 15, T. 18 S., R. 41 E., Malheur Co., Oregon, B. N. Moore, 1931; Miocene.

65+ Bully Creek Formation, USGS 1023, Harper Basin, sec. 34, T. 19 S., R. 42 E., Malheur Co., Oregon, B. N. Moore, 1931; Miocene.

66+ Bully Creek Formation, USGS 1024, Harper Basin, sec. 34, T. 18 S., R. 41 E., Malheur Co., Oregon, B. N. Moore, 1931; Miocene.

67 Lake beds of Burnt River, USGS 1030, Swayze Creek, sec. 11, T. 11 S., R. 43 E., Baker Co., Oregon, B. N. Moore, 1931.

68+ "Truckee" lake beds, USGS 1187, 10 miles N. of Virginia City, Virginia Range, Storey Co., Nevada, V.P. Gianella, 1932.

69*+USGS 1690, upper part of the Cedarville Formation, Forty-nine Camp, Washoe Co., Nevada, 17 miles E. of N. of Cedarville, California, R. S. LaMotte, 1933; 15.6 Ma (Axelrod, 1966), 16.0 Ma corrected.

70+ Unnamed unit, USGS 2280, 15 miles NE. of Weiser, Washington Co., Idaho, R. W. Brown, 1934.

71+ Unnamed unit, USGS 2281, 2.5 miles NE. of Whitebird, Idaho Co., Idaho, on road to Grangeville, R. W. Brown, 1934.

72+ Unnamed unit, USGS 2289, about 2.5 miles NE. of Arrow Junction, Nez Perce Co., Idaho, on road to Juliaetta, R. W. Brown, 1934.

73+ Unnamed unit, USGS 3707, Goose Creek, sec. 35, T. 14 S., R. 20 E., Cassia Co., Idaho, J. R. Gill, 1951.

74*+Esmeralda Formation, USGS 3394, Cedar Mountain, T. 8 N., R. 38 E., Nye Co., Nevada, K. E. Lohman, 1938, about 15.1 Ma (H. E. Schorn, oral commun., 1989).

75*+Unnamed unit, USGS 4213, Silvies Valley, sec. 36, T. 17 S., R. 31 E., Grant Co., Oregon, R. E. Wallace, 1955; about 12.5 Ma (Fiebelkorn and others, 1983).

76+ Latah Formation, USGS 5678, Shelly Lake, sec. 24, T. 25 N., R. 44 E., Spokane Co., Washington, J. W. Hosterman, 1963; Miocene.

77+ Latah Formation, USGS 5679, sec. 15, T. 24 N., R. 43 E., Spokane Co., Washington, J. W. Hosterman, 1963; Miocene.

78+ Latah(?) Formation, USGS 5681, Peone, sec. 27, T. 26 N., R. 44 E., Spokane Co., Washington, J. W. Hosterman, 1963.

79+ Unnamed unit, USGS 6007, sec. 20, T. 24 N., R. 26 E., Churchill Co., Nevada, Ronald Willden, 1966.

80 Unnamed unit, USGS 6035, N. Santiam River, T. 11 S., R. 7 E., Linn Co., Oregon, Harry Wheeler, 1967.

81+ Unnamed unit, USGS 6364, 6371, 6373, Durkee, sec. 23, T. 11 S., R. 43 E., Baker Co., Oregon, R. A. Sheppard, 1970.

82 Unnamed unit, USGS 6368, Durkee, sec. 20, T. 11 S., R. 43 E., Baker Co., Oregon, R. A. Sheppard, 1970.

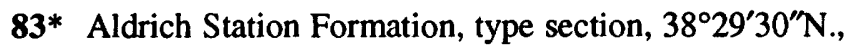
$118^{\circ} 53^{\prime} 21^{\prime \prime}$ W., Mineral Co., Nevada, J. H. Stewart, 1980; 13.0-11.4 Ma (Golia and Stewart, 1984) (13.4-1.7 Ma corrected).

84*+Kate Peak Formation, Eagle-Picher diatomite quarry, Clark Siding, Nevada, T. 20 N., R. 23 E., Storey Co., Nevada; (11.2 $\pm 0.3 \mathrm{Ma}$, AMOCO, unpublished data, 1980).

85*+Mascall Formation, Aldrich Mountain, "meadow locality," Grant Co., Oregon (UCMP loc. P4123); SE $1 / 4$ sec. 14, T. 13 S., R. 28 E.; N. side of east fork of John Day River, Carlton Condit, 1941; (15.4 Ma, Evernden and others, 1964; corrected 15.8 Ma.).

86*+Juntura(?) Formation, Harney Co., Oregon, Stinking Water flora (UCMP loc. P4121); NW $1 / 4$ sec. 17, T. 21 S., R. 35 E.; Carlton Condit, 1941; (12.1 Ma, Evernden and James, 1964; corrected 12.4 Ma).

87+ Mascall Formation, White Hills, Belshaw Ranch locality, Grant Co., Oregon (UCMP loc. P3735); center N1/2 2 sec. 13, T. 13 S., R. 28 E., Carlton Condit.

88+ Mascall Formation, Blue Mountains, Vinegar Creek, Grant Co., Oregon (UCMP loc. P5404); sec. 17, T. 10 S., R. 35 E; 1 mile NW. of Bates on road to Susanville, R. W. Chaney, 1954.

89+ Unnamed unit, Thorn Creek, Boise Co., Idaho (UCMP loc. P4600); sec. 28, T. 5 N., R. 5 E., H.V. Smith, 1941.

90*+Hole-in-the-Wall diatomite quarry, Gooding Co., Idaho, along the drainage of Clover Creek; NW $1 / 4$ sec. 12, T. 4 S., R. 13 E., J. P. Bradbury, 1988; (10.0 Ma, Evernden and others, 1964; corrected 10.3 Ma).

91*+Hole-in-the-Wall diatomite quarry, Gooding Co., Idaho; NE $1 / 4$ sec. 19, T. 3 S., R. 13 E., J. P. Bradbury, 1988; (10.0 Ma, Evernden and others, 1964; corrected $10.3 \mathrm{Ma}$ ).

92*+Quiburis Formation, Edgar Canyon, San Pedro Valley, Pima Co., Arizona, $900 \mathrm{~m} \mathrm{E}$. and $200 \mathrm{~m} \mathrm{~N}$. of SW. corner, sec. 21, T. 11 S., R. 18 E.; J. P. Bradbury, 1980, (5.4-6.6 Ma, Shenk, 1990).

93+ Esmeralda Formation, Black Spring, Nye Co., Nevada; sec. 19, T. 8 N., R. 38 E., Douglas Bergstrom, 1986.

94+ Unnamed unit, N. Fork Fitsum Creek, Valley Co., Idaho; sec. 6, T. 19 N., R. 6 E., B. F. Leonard, 1986.

95+ Esmeralda Formation, Cedar Spring, Nye Co., Nevada; unsurveyed T. 8 N., R. 38 E., Douglas Bergstrom, 1986.

96 Unnamed unit, USGS 642, Baker Co., Oregon; sec. 8, T. 8 S., R. 42 E., B. N. Moore, 1930.

97 Unnamed unit, USGS 1013, Clover Creek District, Baker Co., Oregon; sec. 11, T. 8 S., R. 42 E., B. N. Moore, 1931.

98 Unnamed unit, USGS 1031, Malheur Co., Oregon; sec. 2, T. 15 S., R. 42 E., B. N. Moore, 1931. 
99 Unnamed unit, USGS 1037, Grant Co., Washington; T. 28 N., R. 30 E., (Grand Coulee flora), T. H. Bonser, 1927.

100 Unnamed unit, USGS 1133, 4 miles E. of Basalt, Esmeralda Co., Nevada; T. 2 N., R. 34 E., H. G. Ferguson, 1923.

101 "Truckee" lake beds, USGS 1186, Chalk Bluff, 3 miles W. of Reno, Washoe Co., Nevada; T. 19 N., R. 19E., V. P. Gianella, 1932.

102 Unnamed unit, USGS 2268, Wikiup Damsite, Deschutes River, Deschutes Co., Oregon; T. 22 S., R. 9 E., A. C. Spencer, 1934.

103 Thousand Creek Formation, USGS 3544, Humboldt Co., Nevada; unsurveyed T. 45 N., R. 26 E., K. E. Lohman, 1938.

104* Santa Fe Formation, USGS 4671, Rio Arriba Co., New Mexico; T. 21 N., R. 7 E., R. L. Smith, 1948; ( 8 Ma; Manley and Mehnert, 1981).

105* Alturas Formation, USGS 4690, Modoc Co., California; sec. 7, T. 42 N., R. 12 E., Ian Campbell, 1958; ( 4.8 Ma, see loc. 3).

106+Latah Formation, USGS 5682, Mead, Spokane Co., Washington; sec. 14, T. 26 N., R. 43 E., J. W. Hosterman, 1963.

107* Teewinot Formation, USGS 5935, Teton Co., Wyoming; sec. 36, T. 42 N., R. 116 W., G. W. Andrews, 1966; (9.2 Ma, Evernden and others, 1964; $9.4 \mathrm{Ma}$ corrected).
108+Poison Creek Formation, IW-7, Washington Co., Idaho; SW 1/4, SW 1/4 sec. 29, T. 12 N., R. 6 W., M. J. Evetts, 1979.

109+Poison Creek Formation, IW-8, Washington Co., Idaho; SW 1/4, SW $1 / 4$ sec. 32, T. 12 N., R. 6 W., M. J. Evetts, 1979.

110 IW-9, Poison Creek Formation, Washington Co., Idaho; SE 1/4, SE 1/4 sec. 19, T. 12 N., R. 6 W., M. J. Evetts, 1979.

111+Idaho Group, IW-13, Washington Co., Idaho; NE $1 / 4$, NE $1 / 4$ sec. 19, T. 12 N., R. 4 W., M. J. Evetts, 1979.

112+ AMOCO Becharof No. 1 well, depth $\sim 985 \mathrm{~m}$, $57.78^{\circ} \mathrm{N} ., 157.11^{\circ} \mathrm{W}$., Alaska Peninsula, Alaska, W. N. Krebs, 1985.

113*+Furnace Creek Formation, USGS 4070, Inyo Co., California; 1.15 miles $\mathrm{N} .77^{\circ} \mathrm{W}$. of Travertine Point, road cut on south side of Highway 190. Hard gray limestone $3 \mathrm{ft}$ below base of travertine, K. E. Lohman, 1954; (5.18 $\pm 0.15 \mathrm{Ma}, 6.05 \pm 0.18 \mathrm{Ma}$, $7.35 \pm 0.22 \mathrm{Ma}$, Marvin and Dobson, 1979).

114* Coal Valley Formation sensu Axelrod, 1958, Washoe Co., Nevada; roadcut along Highway 40 W. of Reno, sec. 18 , T. 19 N., R. 19 E.; (<5.7 Ma, Evernden and James, 1964; <5.9. Ma corrected).

115* Coal Valley Formation sensu Axelrod, 1958, Washoe Co., Nevada; Verdi flora locality, sec. 16, T. 19 N., R. 18 E.; (5.7 Ma, Evernden and James, 1964; 5.9 Ma corrected). 


\section{INDEX}

[Boldface page numbers indicate major references]

\section{A}

acanthus, Actinocyclus 3, 4; pl. 1

\section{Achnanthes 5, 7}

Actinocyclus 1, 2

Actinocyclus acanthus 3, 4, 12, 14, 54, 56; pl. 1

cedrus $4,5,10,11,13,14,56$; pls. 2,3 , 4

claviolus $3,5,6,57$; pls. 4,5

cupreus 3, 6, 6, 11, 13, 57; pl. 5

ehrenbergii 3, 6, 7, 11, 14, 58, 59; pls. 6,7

gorbunovii 4, 7, 8, 12

var. fossa $3,7,57$; pl. 7

kanitzii 3; pl. 8

krasskei 3, 6, 7, 9, 12, 13, 14, 57; pls. 8,9

motilis 4, 10, 14, 57; pls. 9, 10, 11

nebulosus 3, 6, 11, 58; pls. 11, 12

nordlingensis $3,4,12$

normanii 3

normanii f. subsalsa 1, 14; pl. 12

pinnulus 3, 4, 11, 58; pls. 12,13

sp. 13

sp. cf. A. gorbunovii 13

sp. cf. A. pinnulus pl. 13

theleus $3,12,14,58$; pls. 13,14

tubulosus $3,4,10,13,58 ; \mathrm{pl} .8$

venenosus $4,5,8,10,13,14,58$; pls. 14,15

Alaska, AMOCO Becharof No. 1 well, (loc. 112) $12,58,67$; pl. 13

Aldrich Mountain, Grant Co., Ore. (loc. 85) $11,58,66$

Aldrich Station Formation type sec., Mineral Co., Nev. (loc. 83) 5, 64, 66

Alturus, Modoc Co., Calif. (loc. 3) 64

Alturas Formation 64, 65, 67

AMOCO Becharof No. 1 well, Alaska (loc. 112) 12, 58, 67; pl. 13

AMOCO Delta Stephan Szot No. 1 well, Cache Co., Utah (loc. 19) 64

AMOCO Lynn Reese No. 1 well, Cache Co., Utah (loc. 39) 65

AMOCO Milford Federal No. 1 Well, Lemhi Co. (loc. 40) 57, 65

Amphora 7

Anomoeoneis 4

apiculatus, Cestodiscus 4

areolae patterns 1
Arizona,

Edgar Canyon, Pima Co. (loc. 92) 7 , 58,$66 ;$ pl. 6

Arrow Junction, Nez Perce Co., Idaho (loc. 72) $10,57,66$; pl. 8

Augusta Mountains, Churchill Co., Nev. (loc. 4) $57 ; \mathrm{pl} .9$

Aulacoseira 5, 7, 11, 14

See also Melosira.

agassizii 11

distans $10,11,13$

granulata 10

islandica 10, 11, 14

lirata 13

praeislandica 10 ,

sp. cf. A. islandica 8

sp. cf. A. distans 11

sp. cf. A. praeislandica $6,12,13$

spp. 5, 9, 10

\section{B}

Baker County, sec. 8, Ore. (loc. 96) 66

Banbury basalt 58

Barstovian age 54

Basalt, Esmeralda Co., Nev. (loc. 100) 67

Beaverdam Formation 56, 65

Belshaw Ranch, White Hills, Grant Co., Ore. (loc. 86) 66

See also White Hills.

Beuem, Vogelsberg Range, Germany 9; pl. 8

Big Smokey Valley, Esmeralda Co., Nev. (loc. 47) 65

Black Spring, Nye Co., Nev. (loc. 93) 11, 57, 58, 66; pls. 11, 12

Blue Mountains, Vinegar Creek, Grant Co., Ore. (loc. 88) 66

See also Vinegar Creek.

Bradys Hot Spring, Churchill Co., Nev. (loc. 54) 65

Browns Hill, Churchill Co., Nev. (loc. 55) 57,65

Bruneau Formation 64

Buffalo Canyon, Churchill Co., Nev. (loc. 6) 11, 58; pl. 11

Buffalo Canyon Formation pl. 11

Bulgaria 59

Bully Creek Formation 4, 56, 57, 58, 64, 66; pl. 1

Burley, sec. 35, Cassia Co., Idaho (loc. 37) 65

Burnt River, lake beds, Swayze Creek, Baker Co., Ore. (loc. 67) 66
C

California 1

Alturas, Modoc Co. (loc. 3) 64

Clear Lake, Lake Co. (loc. 14) 64

Death Valley, Inyo Co. (loc. 113) 7, 59

Dorris, Siskiyou Co. (loc. 60) 65

Howards Gulch, sec. 22, Modoc Co. (loc. 29) 65

Howards Gulch, sec. 27, Modoc Co. (loc. 2) 64

Kettleman Hills, Kings Co. (loc. 58) 65

La Ceja Ridge, Kettleman Hills, Kings Co. (loc. 58) 65

Lake Britton, Shasta Co. (loc. 35) 65

Modoc Co., sec. 7 (loc. 105) 67

Pit River, Modoc Co. (loc. 17) 5; pl. 4

Travertine Point, Inyo Co. (loc. 113) 67

Turner Creek, Modoc Co. (loc. 17) 5, $56,58,64 ; \mathrm{pl} .4$

Caloneis silicula 7

Castle Creek, Owyhee Co., Idaho (loc. 9) 64

Cedar Mountain, Mineral Co., Nev. (loc. 22) $5,10,57,64$; pls. 9,10

Cedar Mountain, Nye Co., Nev. (loc. 74) 4, $11,54,56,57,58,66$; pl. 11

Cedar Spring, Nye Co., Nev. (loc. 95) 58, 66

Cedarville Formation 8, 66; pl. 7

cedrus, Actinocyclus 4, 5, 10, 11, 13, 14, 56; pls. $2,3,4$

Cestodiscus 2

apiculatus 4, 54

cedarensis 5,56

fasciculatus 11, 58

mobilensis 57

mobilis 10, 57

Chaetoceros 5

Chalk Bluff, Reno, Washoe Co., Nev. (loc. 101) 67

Chalk Hills, Owyhee Co., Idaho (loc. 10) 64

Chalk Hills Formation 64

China, Kunming, Xian Feng Basin 13, 58

China, Kunming, Moon-To basin 57

Churchill Co., Nev. (loc. 4) 57; pl. 9

Churchill Co., sec. 20, Nev. (loc. 79) 66

Clarendonian vertebrates 54,58

Clarkia Basin, Shoshone Co., Idaho (loc. 13) 64

Clarkia Basin, Emerald Creek, Benewah Co., Idaho (loc. 21) 12, 13, 58, 64; pls. 13,14

Clarkia Lake deposits 12; pls. 13, 14

claviolus, Actinocyclus 3, 5, 6, 57; pls. 4, 5

Clear Lake, Lake Co., Calif. (loc. 14) 64 
Clover Creek District, Baker Co., Ore. (loc. 97) 66

Coal Valley Formation 13, 58, 64, 67

Columbia River Basalt Group 57, 65

Copper Kettle Canyon, Churchill Co., Nev. (loc. 16) 6, 57, 64; pl. 5

Coscinodiscus 2

(Actinocyclus) miocenicus 2

(= Actinocyclus) gorbunovii 12

(=Actinocyclus) variabilis $2,3,6,6$

gorbunovii 8, 9

v. ethmodiscoidus 8,9

v. gorbunovii 8

miocenicus 9

nevadensis 11,58

subtilis 5,10

cupreus, Actinocyclus 3, 6, 11, 13, 57; pl. 5

Cyclotella 59

Cyclostephanos 59

Cymbella 11, 14

\section{D}

Dead Camel Mountains, Churchill Co., Nev. (loc. 18) 64

Death Valley, Inyo County, Calif. (loc. 113) 7,59

Denticula elegans 7

Diatomite Ridge, Stewart Valley, Mineral Co., Nev. (loc. 20) 5, 56, 64; pls. $2,3,4$

Diploneis interrupta 7

ovalis 7

sp. 14

Dorris, Siskiyou Co., Calif. (loc. 60) 65

Drewsey, Harney County, Ore. (loc. 63) 5, 56,65

Durkee, sec. 23, Baker Co., Oregon (loc. 81) $12,58,66$

Durkee, sec. 20, Baker Co., Oregon (loc. 82) 66

\section{$\mathbf{E}$}

Eagle-Picher diatomite quarry, Clark siding, Storey Co., Nev. (loc. 84) 57, 66

Eastgate, Churchill Co., Nev. (loc. 6) 11

Ecology 14

Edgar Canyon, Pima Co., Ariz. (loc. 92) 7, 58,$66 ;$ pl. 6

ehrenbergii, Actinocyclus $3,6,7,11,14,58$, 59; pls. 6, 7

Ellensburg Formation, Squaw Creek Member $10,11,13,56,57,58,65$; pls. 8 , $9,10,11$

Ellerbeckia arenaria v. teres $5,8,10$

Emerald Creek, Benewah Co., Idaho (loc. 21) $12,13,58,64$; pls. 13,14

Esmeralda Formation 4, 5, 10, 11, 54, 56, $57,58,64,66$; pls. $2,3,4,9,10$, 11,12

Eunotia 5, 10

Eureka County, sec. 31, Nev. (loc. 30) 6, 57, $65 ;$ pl. 5

\section{$\mathbf{F}$}

Fernley, Churchill Co., Nev. (loc. 41) 57, 65

Formations, (and other units)

Aldrich Station Formation 5, 64, 66

Alturas Formation 64, 65, 67

Banbury basalt 58

Beaverdam Formation 56, 65

Bruneau Formation 64

Buffalo Canyon Formation pl. 11

Bully Creek Formation $4,56,57,58$, 64, 66; pl. 1

Cedarville Formation 8, 66; pl. 7

Chalk Hills Formation 64

Clarkia Lake deposits 12; pis. 13, 14

Coal Valley Formation 13, 58, 64, 67

Columbia River Basalt Group 57, 65

Ellensburg Formation, Squaw Creek Member $10,11,13,56,57,58$, 65 ; pls. 8, 9, 10, 11

Esmeralda Formation 4, 5, 10, 11, 54, $56,57,58,64,66$; pls. $2,3,4,9$, $10,11,12$

Furnace Creek Formation 7, 58, 67

Glenns Ferry Formation 64

Horse Hill ash (loc. 11) 64

Humboldt Formation 6, 57, 65; pl. 5

Idaho Group 65; pl. 15

Juntura Formation 57, 65, 66; pl. 2

Kate Peak Formation 57, 66

Kelseyville Formation 64

Latah Formation $10,56,57,58,65,66$, 67

Mascall Formation 10, 11, 12, 57, 58, 66; pls. 8, 9

Poison Creek Formation 8, 13, 58, 65, 67 ; pls. 2, 14, 15

Quiburis Formation 7, 58, 66; pl. 6

Raft River Formation 65

Ringold Formation 65

Santa Fe Formation 67

Sucker Creek Formation 58, 65

Teewinot Formation 67

Thousand Creek Formation 65, 67

Truckee Formation 57, 65, 66, 67

Tulare Formation 65

Yonna Formation 65

Forty-nine Camp, Washoe Co., Nev. (loc. 69) $8,57,66 ;$ pl. 7

Fragilaria brevistriata 7

Fragilaria species $5,7,9,11$

Fragilaria sp. cf. F. virescens 5

Frustulia interposita 7

Furnace Creek Formation 7, 58, 67

\section{G}

Germany, Vogelsberg Range, Beuern 9; pl. 8 Vogelsberg Range, Ruckers 6; pl. 14

Glenns Ferry Formation 64

Gomphonema 11

Goose Creek, Baker Co., Oregon (loc. 27) 5, $10,57,64 ; \mathrm{pl} .9$

Goose Creek, sec. 35, Cassia Co., Idaho (loc. 73) 66 gorbunovii, Actinocyclus 4, 7, 12

Coscinodiscus 8

v. ethmodiscoidus, Coscinodiscus 8

v. gorbunovii, Coscinodiscus 8

var. fossa, Actinocyclus 3, 7, 57; pl. 7

Grand Coulee flora (loc. 99) 67

Grant Co., Wash. (loc. 99) 67

Great Lakes 1

Greece, Macedonia 59

\section{$\mathbf{H}$}

Hagerman horse quarry, Twin Falls Co., Idaho (loc. 23) 64

Halbouty, Michael T. Halbouty Federal No. 1 well, Churchill Co., Nev. (loc. 28) 64

Hangman Valley, Spokane Co., Wash. (loc. 36) 57,65

Harney Co., sec. 17, Ore. (loc. 86) 57, 66

Harper Basin, Malheur Co., Oregon (loc. 7) $10,56,57$; pl. 1

Harper Basin, sec. 15, Malheur Co., Oregon 66

Harper Basin, sec. 34, Malheur Co., Ore. (loc. 65) 66

Harper Basin, sec. 34, Malheur Co., Ore. (loc. 66) 66

Hemidiscaceae 2

Hole-in-the-Wall diatomite quarry, Gooding Co., Idaho (locs. 90, 91) 12, 58, 66; pls. 12, 13

Holocene sediment pls. 6, 7, 12

Horse Hill ash (loc. 11) 64

Howards Gulch, sec. 22, Modoc Co., Calif. (loc. 29) 65

Howards Gulch, sec. 27, Modoc Co., Calif. (loc. 2) 64

Hot Springs Mountains, Churchill Co., Nev. (loc. 56) 57, 65

Humboldt Co., Nev. (loc. 52) 65

Humboldt Co., Nev. (loc. 103) 67

Humboldt Formation 6, 57, 65; pl. 5

Hungary, Szurdokpuspoki, Matra Mountains pl. 8

Hyalodiscus sp. cf. H. laevis 7

Idaho 1

AMOCO Milford Federal No. 1 Well, Lemhi Co. (loc. 40) 57, 65

Arrow Junction, Nez Perce Co. (loc. 72) $10,57,66$; pl. 8

Bruneau Formation 64

Burley, sec. 35, Cassia Co. (loc. 37) 65

Castle Creek, Owyhee Co. (loc. 9) 64

Chalk Hills, Owyhee Co. (loc. 10) 64

Clarkia 12

Clarkia Basin, Shoshone Co. (loc. 13) 64

Clarkia Basin, Emerald Creek, Benewah Co. (loc. 21) 12, 13, 58, 64; pls. 13, 14

Emerald Creek, Benewah Co., (loc. 21) $12,13,58,64$; pls. 13,14 
Idaho-Continued

Goose Creek, sec. 35, Cassia Co. (loc. 73) 66

Hagerman horse quarry, Twin Falls Co. (loc. 23) 64

Hole-in-the-Wall diatomite quarry, Gooding Co. (locs. 90, 91) 12, 58, 66; pls. 12, 13

Juliaetta, Nez Perce Co. (loc. 32) 6, 10, $13,57,58,65$; pls. 5,8

Jungle Point, Idaho Co. (loc. 33) 6, 57, $65 ;$ pls. 4,5

Lowell, Idaho Co. (loc. 33) 6

Malde's (1972) section no. 55, Owyhee Co. (loc. 24) 64

North Fork Fitsum Creek, Valley Co. (loc. 94) 57, 66

Oviatt Creek, Clearwater Co. (loc. 43) $10,12,13,57,58,65 ;$ pl. 14

Owyhee Co. (loc. 12) 64

Reynolds Creek, Owyhee Co. (loc. 44) $13,58,65$; pls. $2,14,15$

Shoofly Creek, Owyhee Co. (loc. 11) 64

Shoofly Creek, sec. 6, Owyhee Co. (loc. 25) 64

Snake River Plain 8, 13 western, Elmore Co. (loc. 5) 64

Thorn Creek, Boise Co. (loc. 89) 66

Trapper Creek, Cassia Co. (loc. 53) 56, 58,65

Washington Co., Idaho Group (loc. 111) 58

Washington Co., sec. 17 (loc. 45) 65

Washington Co., sec. 19, Poison Creek Formation (locs. 110, 111) 67

Washington Co., sec. 29, Poison Creek Formation (loc. 108) 58, 67

Washington Co., sec. 32, Poison Creek Formation (loc. 109) 58, 67

Washington Co., sec. 34 (loc. 31) 65; pl. 15

Weiser, sec. 35, Washington Co. (loc. 26) 64

Weiser, Washington Co. (loc. 70) 57, 66

West Browns Creek, Owyhee Co. (loc. 8) 64

Whitebird, Idaho Co. (loc. 71) 57, 66

Idaho Group 65; pl. 15

\section{J}

Japan, Sea of, Yamato Bank 7, 57; pl. 6 John Day River, Grant Co., Ore. (loc. 85) 66 Juliaetta, Nez Perce Co., Idaho (loc. 32) 6, $10,12,13,57,58,65$; pls. 5,8

Jungle Point, Idaho Co., Idaho (loc. 33) 6, 57,$65 ;$ pls. 4,5

Juntura Formation 57, 65, 66; pl. 2

\section{$\mathbf{K}$}

kanitzii, Actinocyclus 3; pl. 8

Kate Peak Formation 57, 66

Kelseyville Formation 64
Kettleman Hills, Kings Co., Calif. (loc. 58) 65

Key of Actinocyclus species 3

Klamath Falls, Klamath Co., Ore. (loc. 61) 65

krasskei, Actinocyclus 3, 6, 7, 9, 12, 13, 14, $57 ;$ pls. 8,9

\section{$\mathbf{L}$}

La Ceja Ridge, Kettleman Hills, Kings Co. Calif. (loc. 58) 65

Lake Britton, Shasta Co., Calif. (loc. 35) 65

Lake Huron, Michigan pl. 12

Lake Ontario 1, 14

Lander County, New Pass 4

Latah Formation 10, 56, 57, 58, 65, 66, 67

Leslie Gulch, Malheur Co., Ore. (loc. 50) 58, 65

Limnology 14

Localities

Aldrich Mountain, Grant Co., Ore. (loc. 85) $11,58,66$

Aldrich Station Formation, type sec., Mineral Co., Nev. (loc. 83) 66

Alturas, Modoc Co., Calif. (loc. 3) 64

AMOCO Becharof No. 1 well, Alaska (loc. 112) 12, 58, 67; pl. 13

AMOCO Delta Stephan Szot No. 1 well, Cache Co., Utah (loc. 19) 64

AMOCO Lynn Reese No. 1 well, Cache Co., Utah (loc. 39) 65

AMOCO Milford Federal No. 1 Well, Lemhi Co. (loc. 40) 57, 65

Arrow Junction, Nez Perce Co., Idaho (loc. 72) 10, 57, 66; pl. 8

Augusta Mountains, Churchill Co., Wash. (loc. 4) 66

Baker County, sec. 8, Ore. (loc. 96) 66

Basalt, Esmeralda Co., Nev. (loc. 100) 67

Beuern, Vogelsberg Range, Germany 9; pl. 8

Belshaw Ranch, White Hills, Grant Co., Ore. (loc. 86) 66

See also White Hills.

Big Smokey Valley, Esmeralda Co., Nev. (loc. 47) 65

Black Spring, Nye Co., Nev. (loc. 93) 11, 57, 58, 66; pls. 11, 12

Blue Mountains, Vinegar Creek, Grant Co., Ore. (loc. 88) 66

See also Vinegar Creek.

Bradys Hot Spring, Churchill Co., Nev. (loc. 54) 65

Browns Hill, Churchill Co., Nev. (loc. 55) 57,65

Bruneau Formation, Elmore Co., Idaho (loc. 5) 64

Buffalo Canyon, Churchill Co., Nev. (loc. 6) 11, 58; pl. 11

Bulgaria 59

Burley, sec. 35, Cassia Co., Idaho (loc. 37) 65
Localities-Continued

Burnt River, lake beds, Swayze Creek, Baker Co., Ore. (loc. 67) 66

Castle Creek, Owyhee Co., Idaho (loc. 9) 64

Cedar Mountain, Mineral Co., Nev. (loc. 22) 5, 10, 57, 64; pls. 9, 10

Cedar Mountain, Nye Co., Nev. (loc. 74) $4,11,54,56,57,58,66$; pl. 11

Cedar Spring, Nye Co., Nev. (loc. 95) 58,66

Chalk Bluff, Reno, Washoe Co., Nev. (loc. 101) 67

Chalk Hills, Owyhee Co., Idaho (loc. 10) 64

Churchill Co., Nev. (loc. 4) 57; pl. 9

Churchill Co., sec. 20, Nev. (loc. 79) 66

Clarkia Basin, Shoshone Co., Idaho (loc. 13) 64

Clear Lake, Lake Co., Calif. (loc. 14) 64

Clover Creek District, Baker Co., Ore. (loc. 97) 66

Copper Kettle Canyon, Churchill Co., Nev. (loc. 16) 6, 57, 64; pl. 5

Dead Camel Mountains, Churchill Co., Nev. (loc. 18) 64

Death Valley, Inyo Co., Calif. (loc. 113) 7,59

Diatomite Ridge, Stewart Valley, Mineral Co., Nev. (loc. 20) 5, 56, 64; pls. 2, 3, 4

Dorris, Siskiyou Co., Calif. (loc. 60) 65

Drewsey, Harney Co., Ore. (loc. 63) 5, 56,65

Durkee, sec. 20, Baker Co., Oregon (loc. 82) 66

Durkee, sec. 23, Baker Co., Oregon (loc. 81) 12, 58, 66

Eagle-Picher diatomite quarry, Clark siding, Storey Co., Nev. (loc. 84) 57,66

Eastgate, Churchill Co., Nev. (loc. 6) 11

Edgar Canyon, Pima Co., Ariz. (loc. 92) $7,58,66$; pl. 6

Emerald Creek, Benewah Co., Idaho (loc. 21) 12, 13, 58, 64; pls. 13, 14

Eureka Co., sec. 31, Nev. (loc. 30) 6, 57,65 ; pl. 5

Fernley, Churchill Co., Nev. (loc. 41) 57,65

Forty-nine Camp, Washoe Co., Nev. (loc. 69) 8, 57, 66; pl. 7

Goose Creek, Baker Co., Ore. (loc. 27) $5,10,57,64 ;$ pl. 9

Goose Creek, sec. 35, Cassia Co., Idaho (loc. 73) 66

Grant Co., Wash. (loc. 99) 67

Hagerman horse quarry, Twin Falls Co., Idaho (loc. 23) 64

Hangman Valley, Spokane Co., Wash. (loc. 36) 57,65

Harney Co., sec. 17, Ore. (loc. 86) 57, 66 
Localities-Continued

Harper Basin, Malheur Co., Ore. (loc. 7) $4,10,56,57$; pl. 1

Harper Basin, sec 15 Malheur Co., Oregon 66

Harper Basin, sec. 34, Malheur Co., Ore. (loc. 65) 66

Harper Basin, sec. 34, Malheur Co., Ore. (loc. 66) 66

Hole-in-the-Wall diatomite quarry, Gooding Co., Idaho (locs. 90, 91) $12,58,66$; pls. 12,13

Hot Springs Mountains, Churchill Co., Nev. (loc. 56) 57, 65

Howards Gulch, sec. 27, Modoc Co., Calif. (loc. 2) 64

Howards Gulch, sec. 22, Modoc Co., Calif. (loc. 29) 65

Humboldt Co., Nev. (loc. 52) 65

Humboldt Co., Nev. (loc. 103) 67

John Day River, Grant Co., Ore. (loc. 85) 66

Juliaetta, Nez Perce Co., Idaho (loc. 32) $6,10,12,13,57,58,65 ;$ pls. 5,8

Jungle Point, Idaho Co., Idaho (loc. 33) $6,57,65$; pls. 4,5

Klamath Falls, Klamath Co., Ore. (loc. 6165

La Ceja Ridge, Kettleman Hills, Klngs Co., Calif. (loc. 58) 65

Lake Britton, Shașta Co., Calif. (loc. 35) 65

Latah Formation, Spokane Co., Wash. (locs. 77, 78) 66

Leslie Gulch, Malheur Co., Ore. (loc. 50) 58,65

Lowell, Idaho Co., Idaho (loc. 33) 6

Lyon Co., Nev. (loc. 1) 5

Lyon Co., Nev. (loc. 15) 13

Macedonia, Greece 59

Malde's (1972) section no. 55, Owyhee Co., Idaho (loc. 24) 64

Malheur Co., sec. 2, Ore. (loc. 98) 66

Mead, Spokane Co., Wash. (loc. 106) $56,57,58,67$

Michael T. Halbouty Federal No. 1 well, Churchill Co., Nev. (loc. 28) 65

Modoc Co., sec. 7, Calif. (loc. 105) 67

Moon-To Basin, China 57

New Pass, Lander Co., Nev. (loc. 42) 4, 56, 65; pl. 1

New Pass Summit, Churchill Co., Nev. 56,57

Nightingale, Churchill Co., Nev. (loc. 57) 65

North Fork Fitsum Creek, Valley Co., Idaho (loc. 94) 57, 66

North Santiam River, Linn Co., Ore. (loc. 80) 66

Otis Basin, Hamey Co., Ore. 5

Otis Creek, Harney Co., Ore. (loc. 34) 56,65 ; pl. 2

Oviatt Creek, Clearwater Co., Idaho (loc. 43) 10, 12, 13, 57, 65; pl. 14

Owyhee Co., Idaho (loc. 12) 64

Peone, Spokane Co., Wash. (loc. 78) 66
Localities-Continued

Pine Grove Hill, Lyon Co., Nev. (loc. 15) 58,64

Pit River, Modoc Co., Calif. (loc. 17) 5

Reno, Washoe Co., Nev. (loc. 101) 67

Reynolds Creek, Owyhee Co., Idaho (loc. 44) 13, 58, 65; pls. 2, 14, 15

Rio Arriba Co., N. Mex. (loc. 104) 67

Ruckers, Vogelsberg Range, Germany 6; pl. 14

Saginaw Bay, Lake Huron, Michigan pl. 12

Seven Mile Creek, Umatilla Co., Ore. (loc. 38) 57, 65

Shelly Lake, Spokane Co., Wash. (loc. 76) 66

Shoofly Creek, Owyhee Co., Idaho (loc. 11) 64

Shoofly Creek, sec. 6, Owyhee Co., Idaho (loc. 25) 64

Silvies Valley, Grant Co., Ore. (loc. 75) $5,56,57,66$

Snake River Plain, Idaho 8

Snake River Plain, western, Elmore Co., Idaho (loc. 5) 64

Soviet Union. See Russia.

Spokane Co., Wash. (loc. 76) 57, 58, 66

Spokane Co., Wash. (loc. 77) 10, 66

Stewart Valley, Mineral Co., Nev. (loc. 20) 5

Stillwater Mountains, Churchill Co., Nev. (loc. 16) 7

Stillwater Mountains, southern, Churchill Co., Nev. (loc. 48) 56, 57, 65; pls. 2, 3

Swayze Creek, Baker Co., Ore. (loc. 51) 65

Szurdokpuspoki, Matra Mountains, Hungary pl. 8

Teton Co., sec. 36, Wyoming (loc. 107) 67

Thorn Creek, Boise Co., Idaho (loc. 89) 66

Trapper Creek, Cassia Co., Idaho (loc. 53) $56,58,65$

Travertine Point, Inyo Co., Calif. (loc. 113) 67

Tucson, Pima Co., Ariz. (loc. 92) 58

Turner Creek, Modoc Co., Calif. (loc. 17) $5,56,58,64$; pl. 4

Vantage, Grant Co., Wash. (loc. 59) 10, $56,57,65$

Vinegar Creek, Grant Co., Oregon (loc. 88) $10,57,66$; pls. 8,9

Virginia City, Storey Co., Nev. (loc. 68) $5,56,57,66$

Virginia Range, Storey Co., Nev. (loc. 68) $5,56,57,66$

Vogelsberg Range, Beuern, Germany 9 ; pl. 8

Vogelsberg Range, Ruckers, Germany 6; pl. 14

Walker River, Lyon Co., Nev. (loc. 1) 64
Washington Co., Idaho, Idaho Group (locs. 111) 58

Localities-Continued

Washington Co., sec. 17, Idaho (loc. 45) 65

Washington Co., sec. 19, Idaho, Poison Creek Formation (locs. 110, 111) 67

Washington Co., sec. 29, Idaho, Poison Creek Formation (loc. 108) 58, 67

Washington Co., sec. 32 Idaho, Poison Creek Formation (loc. 109) 58, 67

Washington Co., sec. 34, Idaho (loc. 31) 65 ; pl. 15

Washoe Co., Nev. (locs. 114, 115) 67

Weiser, sec. 35, Washington Co., Idaho (loc. 26) 64

Weiser, Washington Co., Idaho (loc. 70) 57,66

West Browns Creek, Owyhee Co., Idaho (loc. 8) 64

Westfall, Harper Basin, Malheur Co., Ore. (loc. 64) 66

White Cliffs, Franklin Co., Wash. (loc. 46) 65

White Hills, Grant Co., Oregon (loc. 87) $12,13,57,58,66$

Whitebird, Idaho Co., Idaho (loc. 71) 57,66

Wikiup Damsite, Deschutes River, Deschutes Co., Ore. (loc. 102) 67

Xian Feng Basin, China 13, 58

Yakima Co., Washington (loc. 49) 10, $11,56,57,58,65 ;$ pls. 8, 9, 10, 11

Yamato Bank, Sea of Japan 7, 57; pl. 6

Yonna Valley, Klamath Co., Ore. (loc. 62) 65

Lowell, Idaho Co., Idaho 6

Lyon Co., Nev. (loc. 1) 5

Lyon Co., Nev. (loc. 15) 13

\section{$\mathbf{M}$}

Macedonia, Greece 59

Malde's (1972) section no. 55, Owyhee Co., Idaho (loc. 24) 64

Malheur Co., sec. 2, Ore. (loc. 98) 66

Mascall Formation 10, 11, 12, 57, 58, 66; pls. 8,9

Mastogloia braunii 7

Mastogloia elliptica 7

Mead, Spokane Co., Wash. (loc. 106) 56, 57, 58,67

Melosira moniliformis 7

Melosira undulata 10

Mesodictyon 12, 58

Michael T. Halbouty Federal No. 1 well, Churchill Co., Nev. (loc. 28) 65

Michigan

Saginaw Bay, Lake Huron pl. 12 miocenicus, Coscinodiscus (Actinocyclus) 2 Modoc Co., sec. 7, Calif. (loc. 105) 67

Moon-To Basin, China 57

motilis, Actinocyclus 4, 10, 14, 57; pls. 9, 10,11 
$\mathbf{N}$

Namibia, Walvis Bay pls. 6, 7

Navicula 7, 11, 14

nebulosus, Actinocyclus 3, 6, 11, 58; pls. 11, 12

Nevada 1

Aldrich Station Formation, type sec., Mineral Co. (loc. 83) 67

Augusta Mountains, Churchill Co. (loc. 4) $57 ; \mathrm{pl} .9$

Basalt, Esmeralda Co. (loc. 100) 67

Big Smokey Valley, Esmeralda Co. (loc. 47) 65

Black Spring, Nye Co. (loc. 93) 11, 57, 58,$66 ;$ pls. 11,12

Bradys Hot Spring, Churchill Co. (loc. 54) 65

Browns Hill, Churchill Co. (loc. 55) 57, 65

Buffalo Canyon, Churchill Co. (loc. 6) 11, 58; pl. 11

Cedar Mountain, Mineral Co. (loc. 22) 5, 10, 57, 64; pls. 9, 10

Cedar Mountain, Nye Co. (loc. 74) 4 , $11,54,56,57,58,66 ;$ pl. 11

Cedar Spring, Nye Co. (loc. 95) 58, 66

Chalk Bluff, Reno, Washoe Co. (loc. 101) 67

Churchill Co., sec. 20 (loc. 79) 66

Churchill Co., sec. 31 (loc. 4) 57; pl. 9

Copper Kettle Canyon, Churchill Co. (loc. 16) 6, 57, 64; pl. 5

Dead Camel Mountains, Churchill Co. (loc. 18) 64

Diatomite Ridge, Stewart Valley, Mineral Co. (loc. 20) 5, 56, 64; pls. 2 , 3,4

Eagle-Picher diatomite quarry, Clark siding, Storey Co. (loc. 84) 57, 66

Eastgate, Churchill Co. (loc. 6) 11

Eureka Co. sec. 31 (loc. 30) 6, 57, 65; pl. 5

Fernley, Churchill Co. (loc. 41) 57, 65

Forty-nine Camp, Washoe Co. (loc. 69) 8, 57, 66; pl. 7

Hot Springs Mountains, Churchill Co. (loc. 56) 57, 65

Humboldt Co. (loc. 52) 65

Humboldt Co. (loc. 103) 67

Lyon Co. (loc. 1) 5

Lyon Co. (loc. 15) 13

Michael T. Halbouty Federal No. 1 well, Churchill Co. (loc. 28) 65

New Pass, Lander Co. (loc. 42) 4, 56, $65 ;$ pl. 1

New Pass Summit, Churchill Co. 56, 57

Nightingale, Churchill Co. (loc. 57) 65

Pine Grove Hills, Lyon Co. (loc. 15) 58,64

Reno, Washoe Co., (loc. 101) 67

Stewart Valley, Mineral Co. (loc. 20) 5

Stillwater Mountains, Churchill Co. (loc. 16) 7
Stillwater Mountains, southern, Churchill Co. (loc. 48) 56, 57, 65; pls. 2 , 3

Virginia City, Storey Co. (loc. 68) 5, 57,66

Walker River, Lyon Co. (loc. 1) 64

Washoe Co. (locs. 114, 115) 67

New Mexico,

Rio Arriba Co. (loc. 104) 67

New Pass, Lander County, Nev. (loc. 42) 4, 56,65 ; pl. 1

New Pass Summit, Churchill Co., Nev. 56, 57

Nightingale, Churchill Co., Nev. (loc. 57) 65

Nitzschia 7

nordlingensis, Actinocyclus 3, 4, 12

normanii, Actinocyclus 3

normanii f. subsalsa, Actinocyclus 1, 14; pl. 12

North Fork Fitsum Creek, Valley Co., Idaho (loc. 94) 57, 66

North Santiam River, Linn Co., Ore. (loc. 80) 66

\section{$\mathbf{O}$}

Ontario, Lake 1

Oregon 1

Aldrich Mountain, Grant Co. (loc. 85) $11,58,66$

Baker County, sec. 8 (loc. 96) 66

Belshaw Ranch, White Hills, Grant Co. (loc. 86) 66

Burnt River, lake beds, Swayze Creek, Baker Co. (loc. 67) 66

Clover Creek District, Baker Co. (loc. 97) 66

Drewsey, Harney Co. (loc. 63) 5, 56, 65

Durkee, sec. 20, Baker Co. (loc. 82) 66

Durkee, sec. 23, Baker Co. (loc. 81) 12, 58,66

Goose Creek, Baker Co. (loc. 27) 5, 10, 57, 64; pl. 9

Harney Co., sec. 17 (loc. 86) 57, 66

Harper Basin, Malheur Co. (loc. 7) 4, $10,56,57$; pl. 1

Harper Basin, sec. 34, Malheur Co. (loc. 65) 66

Harper Basin, sec. 34, Malheur Co. (loc. 66) 66

John Day River, Carlton condit, Grant Co. (loc. 85) 66

Klamath Falls, Klamath Co. (loc. 61) 65

Leslie Gulch, Malheur Co. (loc. 50) 58, 65

Malheur Co., sec. 2 (loc. 98) 66

North Santiam River, Linn Co. (loc. 80) 66

Otis Basin, Harney Co. 5

Otis Creek, Harney Co. (loc. 34) 56, 65 ; pl. 2

Seven Mile Creek, Umatilla Co. (loc. 38) 57,65
Silvies Valley, Grant Co. (loc. 75) 5, $56,57,66$

Swayze Creek, Baker Co. (loc. 51) 65

Vinegar Creek, Grant Co. (loc. 88) 10, 57, 66; pls. 8, 9

Westfall, Harper Basin, Malheur Co. (loc. 64) 66

White Hills, Grant Co.(loc. 87) 12, 13, $57,58,66$

Wikiup Damsite, Deschutes River, Deschutes Co. (loc. 102) 67

Yonna Valley, Klamath Co. (loc. 62) 65

Otis Basin, Harney Co., Ore. 5

Otis Creek, Harney Co., Ore. (loc. 34) 56, $65 ;$ pl. 2

Oviatt Creek, Clearwater Co., Idaho (loc. 43) $10,12,13,57,65$; pl. 14

Owyhee Co., Idaho (loc. 12) 64

\section{$\mathbf{P}$}

Paleoecology 14

Paleolakes 1

Peone, Spokane Co., Wash. (loc. 78) 66

Pine Grove Hills, Lyon Co., Nev. (loc. 15) 58,64

Pinnularia 4, 7, 11

pinnulus, Actinocyclus 3, 4, 11, 58; pls. 12, 13

Pit River, Modoc Co., Calif. (loc. 17) 5

Poison Creek Formation 8, 13, 58, 65, 67; pls. 2, 14, 15

Pontodiscus 2

Pontodiscus gorbunovii 9

Pontodiscus (=Coscinodiscus) miocenicus 10

Preparation 2

Preservation (diatom) 53

Q

Quiburis Formation 7, 58, 66; pl. 6

\section{$\mathbf{R}$}

Radiometric dating 53

Raft River Formation 65

References 14, 59

Reno, Washoe Co., Nev. (loc. 101) 67

Reworking of diatoms 53

Reynolds Creek, Owyhee Co., Idaho (loc. 44) $13,58,65$; pls. $2,14,15$

Rhine graben, Germany

Ringold Formation 65

Rio Arriba Co., N. Mex. (loc. 104) 67

Ruckers, Vogelsberg Range, Germany 6; pl. 14

Russia, Siberia 10

Primor region, Siberia 13

Tim River, Siberia 13

\section{$\mathbf{S}$}

Saginaw Bay, Lake Huron, Michigan pl. 12 San Pedro Valley, Ariz. See Edgar Canyon. Santa Fe Formation 67 
Seven Mile Creek, Umatilla Co., Ore. (loc. 38) 57,65

Shelly Lake, Spokane Co., Wash. (loc. 76) 66

Shoofly Creek, sec. 6, Owyhee Co., Idaho (loc. 25) 64

Shoofly Creek, sec. 9, Owyhee Co., Idaho (loc. 11) 64

Siberia, Russia 10

Silvies Valley, Grant Co., Ore. (loc. 75) 5 , $56,57,66$

Snake River Plain, Idaho 8, 13

Snake River Plain, western, Elmore Co., Idaho (loc. 5) 64

Soviet Union 59

See also Russia.

Spokane Co., Wash. (loc. 76) 57, 58, 66

Spokane Co., Wash. (locs. 77, 78) 10, 66

Squaw Creek Member, Ellensburg Formation $10,11,13,56,57,58,65$; pls. 8 , $9,10,11$

Stauroneis 14

Stephanodiscus 2, 59

Stephanodiscus astraea 10

Stewart Valley, Mineral Co., Nev. (loc. 20) 5

Stillwater Mountains, Churchill Co., Nev. (loc. 16) 7

Stillwater Mountains, southern, Churchill Co., Nev. (loc. 48) 56, 57, 65; pls. 2, 3

Stinking Water flora (loc. 86) 66

Sucker Creek Formation 58, 65

Surirella 4

Swayze Creek, Baker Co., Ore. (loc. 51) 65

Szurdokpuspoki, Matra Mountains, Hungary pl. 8

\section{$\mathbf{T}$}

Tabellaria 5, 10

Techniques, collection and preparation 2

Teewinot Formation 67

Teton Co., sec. 36, Wyoming (loc. 107) 67

Tetracyclus 5, 7, 10, 11, 14 ellipticus 8

sp. 5,14

theleus, Actinocyclus 3, 12, 14, 58; pls. 13, 14

Thom Creek, Boise Co., Idaho (loc. 89) 66

Thousand Creek Formation 65, 67

Tim River, Siberia, Russia 13

Time range 58

Trapper Creek, Cassia Co., Idaho (loc. 53) $56,58,65$
Travertine Point, Inyo Co., Calif. (loc. 113) 67

Truckee Formation 57, 65, 66

tubulosus, Actinocyclus 3, 4, 10, 13, 58; pl. 8

Tucson, Pima Co., Ariz. (loc. 92) 58

Tulare Formation 65

Turner Creek, Modoc Co., Calif. (loc. 17) 5, $56,58,64$; pl. 4

$$
\mathbf{U}, \mathbf{V}
$$

Utah,

AMOCO Delta Stephan Szot No. 1 well, Cache Co. (loc. 19) 64

AMOCO Lynn Reese No. 1 well, Cache Co. (loc. 39) 65

Vantage, Grant Co., Wash. (loc. 59) 10, 56, 57,65

variabilis, Coscinodiscus (=Actinocyclus) 2 , 3, 6

venenosus, Actinocyclus 4, 5, 8, 10,13, 14 , 58; pls. 14, 15

Vinegar Creek, Grant Co., Oregon (loc. 88) 10, 57, 66; pls. 8, 9

Virginia City, Storey Co., Nev. (loc. 68) 5 , $56,57,66$

Virginia Range, Storey Co., Nev. (loc. 68) 5 , $56,57,66$

Vogelsberg Range, Beuern, Germany 6; pl. 8

Vogelsberg Range, Ruckers, Germany 9; pl. 14

\section{W}

Walker River, Lyon Co., Nev. (loc. 1) 64

Walvis Bay, Namibia pls. 6, 7

Washington 1

Grant Co. (loc. 99) 67

Hangman Valley, Spokane Co. (loc. 36) 57,65

Mead, Spokane Co. (loc. 106) 56, 57, 58,67

Peone, Spokane Co. (loc. 78) 66

Shelly Lake, Spokane Co. (loc. 76) 66

Spokane Co. (loc. 76) 57, 58, 66

Spokane Co. (loc. 77) 10

Vantage, Grant Co. (loc. 59) 10, 56, 57, 65

White Cliffs, Frankiin Co. (loc. 46) 65

Yakima Co. (loc. 49) 10, 11, 56, 57, 58, 65 ; pls. 8, 9, 10, 11

Washoe Co., Nev. (locs. 114, 115) 67
Washington Co., sec. 17, Idaho (loc. 45) 65

Washington Co., sec. 19, Idaho, Poison Creek Formation (locs. 110, 111) 67

Washington Co., sec. 29, Idaho, Poison Creek Formation (loc. 108) 58, 67

Washington Co., sec. 32, Idaho, Poison Creek Formation (loc. 109) 58, 67

Washington Co., sec. 34, Idaho (loc. 31) 65; pl. 15

Washington Co., Idaho, Idaho Group (loc. 111) 58

Weiser, sec. 35, Washington Co., Idaho (loc. 2664

Weiser, Washington Co., Idaho (loc. 70) 57, 66

Wells

AMOCO Becharof No. 1 well, Alaska (loc. 112) 12, 58, 67; pl. 13

AMOCO Delta Stephan Szot No. 1 well, Cache Co., Utah (loc. 19) 64

AMOCO Lynn Reese No. 1 well, Cache Co., Utah (loc. 39) 65

AMOCO Milford Federal No. 1 Well, Lemhi Co. (loc. 40) 57

Michael T. Halbouty Federal No. 1 well, Churchill Co., Nev, (loc. 28) 65

West Browns Creek, Owyhee Co., Idaho (loc. 8) 64

Westfall, Harper Basin, Malheur Co., Ore. (loc. 64) 66

White Cliffs Franklin Co., Wash. (loc. 46) 65

White Hills, Grant Co., Oregon (loc. 87) 12, $13,57,58,66$

Whitebird, Idaho Co., Idaho (loc. 71) 57, 66

Wikiup Damsite, Deschutes River, Deschutes Co., Ore. (loc. 102) 67

Wyoming,

Teton Co., sec. 36 (loc. 107) 67

\section{$\mathbf{X}, \mathbf{Y}$}

Xian Feng Basin, Kunming, China 13, 58

Yakima Co., Washington (loc. 49) 10, 11, $56,57,58,65$; pls. 8, 9, 10, 11

Yamato Bank, Sea of Japan 7, 57; pl. 6

Yonna Formation 65

Yonna Valley, Klamath Co., Ore. (loc. 62) 65 


\section{SELECTED SERIES OF U.S. GEOLOGICAL SURVEY PUBLICATIONS}

\section{Periodicals}

Earthquakes \& Volcanoes (issued bimonthly).

Preliminary Determination of Epicenters (issued monthly).

\section{Technical Books and Reports}

Professional Papers are mainly comprehensive scientific reports of wide and lasting interest and importance to professional scientists and engineers. Included are reports on the results of resource studies and of topographic, hydrologic, and geologic investigations. They also include collections of related papers addressing different aspects of a single scientific topic.

Bulletins contain significant data and interpretations that are of lasting scientific interest but are generally more limited in scope or geographic coverage than Professional Papers. They include the results of resource studies and of geologic and topographic investigations; as well as collections of short papers related to a specific topic.

Water-Supply Papers are comprehensive reports that present significant interpretive results of hydrologic investigations of wide interest to professional geologists, hydrologists, and engineers. The series covers investigations in all phases of hydrology, including hydrology, availability of water, quality of water, and use of water.

Circulars present administrative information or important scientific information of wide popular interest in a format designed for distribution at no cost to the public. Information is usually of short-term interest.

Water-Resources Investigations Reports are papers of an interpretive nature made available to the public outside the formal USGS publications series. Copies are reproduced on request unlike formal USGS publications, and they are also available for public inspection at depositories indicated in USGS catalogs.

Open-File Reports include unpublished manuscript reports, maps, and other material that are made available for public consultation at depositories. They are a nonpermanent form of publication that may be cited in other publications as sources of information.

\section{Maps}

Geologic Quadrangle Maps are multicolor geologic maps on topographic bases in $71 / 2$ - or 15 -minute quadrangle formats (scales mainly $1: 24,000$ or $1: 62,500$ ) showing bedrock, surficial, or engineering geology. Maps generally include brief texts; some maps include structure and columnar sections only.

Geophysical Investigations Maps are on topographic or planimetric bases at various scales, they show results of surveys using geophysical techniques, such as gravity, magnetic, seismic, or radioactivity, which reflect subsurface structures that are of economic or geologic significance. Many maps include correlations with the geology.

Miscellaneous Investigations Series Maps are on planimetric or topographic bases of regular and irregular areas at various scales; they present a wide variety of format and subject matter. The series also includes 7 1/2-minute quadrangle photogeologic maps on planimetric bases which show geology as interpreted from aerial photographs. The series also includes maps of Mars and the Moon.
Coal Investigations Maps are geologic maps on topographic or planimetric bases at various scales showing bedrock or surficial geology, stratigraphy, and structural relations in certain coal-resource areas.

Oil and Gas Investigations Charts show stratigraphic information for certain oil and gas fields and other areas having petroleum potential.

Miscellaneous Field Studies Maps are multicolor or black-andwhite maps on topographic or planimetric bases on quadrangle or irregular areas at various scales. Pre-1971 maps show bedrock geology in relation to specific mining or mineral-deposit problems; post-1971 maps are primarily black-and-white maps on various subjects such as environmental studies or wilderness mineral investigations.

Hydrologic Investigations Atlases are multicolored or black-andwhite maps on topographic or planimetric bases presenting a wide range of geohydrologic data of both regular and irregular areas; the principal scale is $1: 24,000$, and regional studies are at $1: 250,000$ scale or smaller.

\section{Catalogs}

Permanent catalogs, as well as some others, giving comprehensive listings of U.S. Geological Survey publications are available under the conditions indicated below from USGS Map Distribution, Box 25286, Building 810, Denver Federal Center, Denver, CO 80225. (See latest Price and Availability List.)

"Publications of the Geological Survey, 1879-1961" may be purchased by mail and over the counter in paperback book form and as a set microfiche.

"Publications of the Geological Survey, 1962-1970"may be purchased by mail and over the counter in paperback book form and as a set of microfiche.

"Publications of the U.S. Geological Survey, 1971-1981" may be purchased by mail and over the counter in paperback book form (two volumes, publications listing and index) and as a set of microfiche.

Supplements for 1982, 1983,1984, 1985, 1986, and for subsequent years since the last permanent catalog may be purchased by mail and over the counter in paperback book form.

State catalogs, "List of U.S. Geological Survey Geologic and Water-Supply Reports and Maps For (State)," may be purchased by mail and over the counter in paperback booklet form only.

"Price and Availability List of U.S. Geological Survey Publications," issued annually, is available free of charge in paperback booklet form only.

Selected copies of a monthly catalog "New Publications of the U.S. Geological Survey" is available free of charge by mail or may be obtained over the counter in paperback booklet form only. Those wishing a free subscription to the monthly catalog "New Publications of the U.S. Geological Survey" should write to the U.S. Geological Survey, $582 \mathrm{Na}$ tional Center, Reston, VA 22092.

Note--Prices of Government publications listed in older catalogs, announcements, and publications may be incorrect. Therefore, the prices charged may differ from the prices in catalogs, announcements, and publications. 